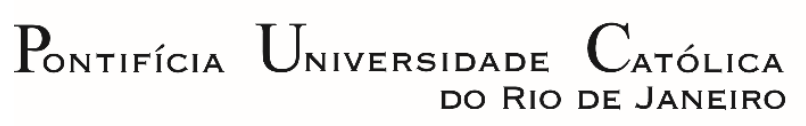

DO RIO DE JANEIRO

Julia Ramos Campana

Design de Interfaces Gráficas de Sistemas Robóticos: Um estudo de Usabilidade e Interação Humano-Máquina

Dissertação de Mestrado

Dissertação apresentada ao Programa de Pósgraduação em Design da PUC-Rio como requisito parcial para obtenção do grau de Mestre em Design.

Orientadora: Profa. Maria Manuela Rupp Quaresma

Rio de Janeiro, 04 de Abril de 2018 


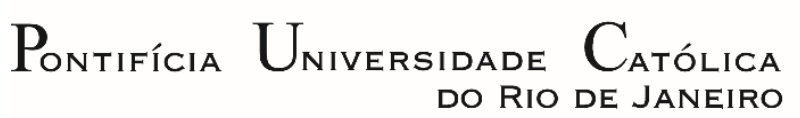

DO RIO DE JANEIRO

Julia Ramos Campana

\title{
Design de interfaces gráficas de sistemas robóticos: Um estudo de Usabilidade e Interação \\ Humano-Máquina
}

Dissertação apresentada ao Programa de Pós-graduação em Design da PUC-Rio como requisito parcial para obtenção do grau de Mestre em Design. Aprovada pela Comissão Examinadora abaixo assinada.

\author{
Prof ${ }^{a} \cdot$ Maria Manuela Rupp Quaresma \\ Orientadora \\ Departamento de Artes \& Design - PUC-Rio \\ Prof. João de Sá Bonelli \\ Departamento de Artes \& Design - PUC-Rio \\ Prof. Alessandro Jacoud Peixoto \\ Universidade Federal do Rio de Janeiro (UFRJ) \\ Profa. Monah Winograd \\ Coordenadora Setorial do Centro de Teologia \\ e Ciências Humanas - PUC-Rio
}

Rio de Janeiro, 04 Abril de 2018 
Todos os direitos reservados. É proibida a reprodução total ou parcial do trabalho sem autorização da universidade, da autora e da orientadora.

\section{Julia Ramos Campana}

Possui Especialização em Design Digital pela Vancouver Film School (2009) e em Gerenciamento de Projetos pela University of British Columbia (2010). É graduada em Professional and Technical Communication, pelo Illinois Institute of Technology (2007). Trabalhou como UI Designer na Microsoft Game Studios, entre 2009 e 2013, em Vancouver, Canadá. Na Xbox Live Division, participou de projetos em jogos (Kinect Sports 2 e JoyRide) e aplicativos (NHL Live, NBA Live e UFC). Atuou como pesquisadora no LEAD entre 2013 e 2016 no (Laboratório de Controle e Automação, Engenharia de Aplicação e Desenvolvimento da Coppe), na área de Design de Experiências e Interação Humano Computador, difundindo aspectos e processos ligados ao design centrado no usuário em projetos de Robótica. Atualmente, é pesquisadora na startup 13 Robotics.

Ficha Catalográfica

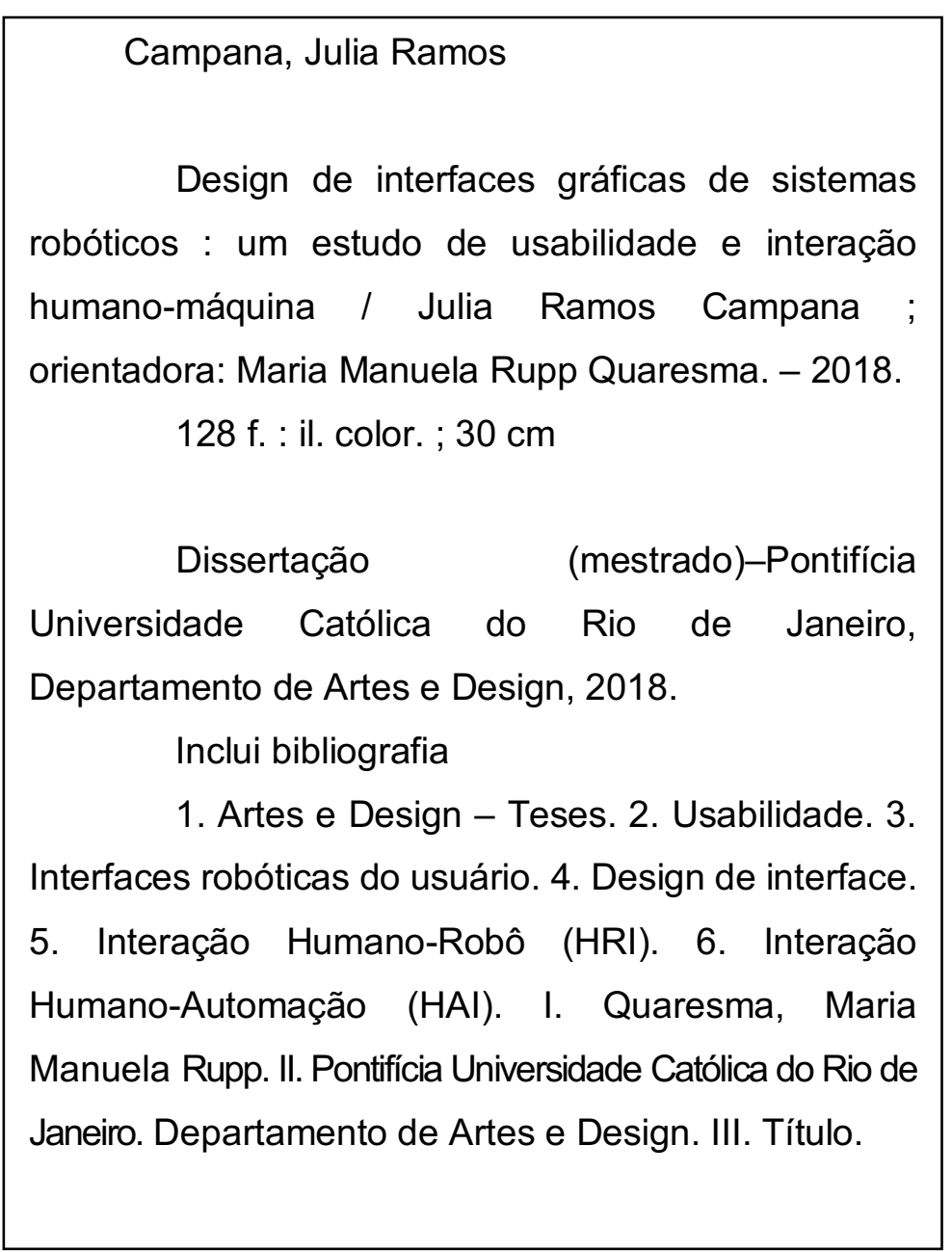




\section{Agradecimentos}

À orientadora Manuela Quaresma, por ter acreditado no meu projeto e pela orientação na minha iniciação a pesquisa.

Aos meus pais, Jorge e Luiza, pela dedicação e amor, por sempre acreditarem em mim, e por terem me ensinado que o conhecimento é um bem irrefutável e necessário nessa vida.

Ao LEAD-UFRJ (Laboratório de Controle e Automação, Engenharia de Aplicação e Desenvolvimento - COPPE/UFRJ), por abrir as portas para meu retorno profissional ao Brasil e por todo o suporte durante esta pesquisa.

À 13 Robotics, e a ESBR (Energia Sustentável do Brasil) por investir na minha formação profissional e acadêmica.

À amiga Patrícia Carrion, pelo suporte técnico e amizade durante este mestrado.

Aos participantes voluntários das entrevistas contextuais e do Teste de Usabilidade, por disponibilizarem tempo (e paciência) à aplicação dos testes, e cuja participação foi essencial à realização deste trabalho.

À PUC-Rio e aos professores e funcionários do Departamento de Artes \& Design.

À Vinícius Pabón pelo encontro de amor que me trouxe tanta inspiração e alegria neste período. 


\section{Resumo}

Ramos Campana, Julia; Quaresma, Manuela (Orientadora). Design de interfaces gráficas de sistemas robóticos: Um estudo de Usabilidade e Interação Humano-Máquina. Rio de Janeiro, 2018. 128p. Dissertação de Mestrado - Departamento de Artes \& Design, Pontifícia Universidade Católica do Rio de Janeiro.

Hoje, os constantes avanços tecnológicos em interfaces digitais, e por consequência as interfaces gráficas do usuário, se fazem cada vez mais presentes na interação humano-máquina. Porém, num contexto em que sistemas inteligentes, a exemplo dos sistemas robóticos, já são uma realidade, ainda restam lacunas a serem preenchidas quando se pensa em integrar, com fluidez, robôs a trabalhos customizados e complexos. Esta pesquisa tem como foco a análise da usabilidade de interfaces de usuário específicas para a interação com robôs remotos também conhecidas como Robot User Interfaces (RUIs). Quando bem executadas, tais interfaces permitem aos operadores realizar remotamente tarefas em ambientes complexos. Para tanto, trabalha-se com a hipótese de que, se RUIs forem concebidas considerando as especificidades desses modelos de interação, as falhas operacionais serão reduzidas. O objetivo desta pesquisa foi avaliar diretrizes específicas para sistemas robóticos, compreendendo a relevância destas na usabilidade de interfaces. Para uma base teórica, foram levantados os modelos já existentes de interação com robôs e sistemas automatizados; e os princípios de design que se aplicam a estes modelos. Após a revisão bibliográfica, foram realizadas entrevistas contextuais com usuários de sistemas robóticos e testes de usabilidade, a fim de reproduzir, em interfaces com e sem diretrizes de RUIs, os processos de interação na realização de tarefas. Os resultados finais das técnicas aplicadas apontaram para a validade da hipótese - se interfaces específicas para sistemas robóticos forem concebidas considerando as especificidades dos modelos de interação humano-robô, as falhas operacionais na interação serão reduzidas - à medida que os sistemas desenvolvidos com interfaces específicas ao contexto de interação com robôs proporcionaram uma melhor usabilidade e mitigaram a ocorrência de uma série de possíveis falhas humanas. 


\section{Palavras-chave}

Usabilidade; Interfaces Robóticas do Usuário; Design de Interface; Interação Humano-Robô (HRI); Interação Humano-Automação (HAI); Diretrizes de Design. 


\section{Abstract}

Ramos Campana, Julia; Quaresma, Manuela (Advisor). Design of graphical robot user interfaces: A study of Usability and Human-Machine Interaction. Rio de Janeiro, 2018. 128p. Dissertação de Mestrado Departamento de Artes \& Design, Pontifícia Universidade Católica do Rio de Janeiro.

Nowadays, the constant technological advances, and consequently the graphical user interfaces, have become more and more present in the humanmachine interaction. However, in a context where intelligent systems, such as robotic systems, are already a reality, there are still gaps to be filled when we think about integrating robots with custom and complex activities. This research aims on the analysis of Robot User Interfaces (RUIs)' usability. When well executed, such interfaces allow operators to remotely perform tasks in complex environments. To that intent, our hypothesis is that, if RUIs are conceived considering the specificities of these interaction models, operational failures will be reduced. The main goal of this research was to evaluate specific guidelines for robotic systems, understanding their relevance in usability. For a theoretical basis, the existing models of interaction with robots and autonomous systems were raised; as well as the design principles that apply to these models. After a bibliographic review, we conducted contextual interviews with users of robotic systems, and usability tests to reproduce, in interfaces with and without RUI guidelines, the interaction processes in the task completion. The final results of the applied techniques proved the validity of the hypothesis, as the systems developed with interfaces specific to the interaction with robots provided better usability and mitigated the occurrence of array of human faults.

\section{Keywords}

Usability; Robot User Interfaces (RUI); Interface Design; Human Robot Interaction (HRI); Human Automation Interaction (HAI); Design Guidelines. 
There's a time when the operation of the machine becomes so odious, makes you so sick at heart, that you can't take part! You can't even passively take part! And you've got to put your bodies upon the gears and upon the wheels...upon the levers, upon all the apparatus, and you've got to make it stop! And you've got to indicate to the people who run it, to the people who own it, that unless you're free, the machine will be prevented from working at all! 


\section{Sumário}

1 Introdução

2 Sobre sistemas robóticos e o desenvolvimento de GUls 16

2.1. A robótica de serviço 17

2.2. Sistemas robóticos de controle de máquina In Situ 21

2.3. Sistema operacional robótico 22

2.4. GUls na robótica 23

3 Interação com sistemas automatizados e sistemas robóticos 27

3.1. Modelo de Interação Humano-Automação 28

3.1.1. Paradigma do controle de supervisão 29

3.1.2. OODA Loop 31

3.1.3. Falhas com Automação 32

3.1.4. Tipos de erros com automação 36

3.2. Modelo de Interação Humano-Robô 38

3.3. O papel do ser humano na interação com robôs 40

4 Usabilidade e design no desenvolvimento de RUls 42

4.1. Princípios de Design na Interação com robôs 43

4.2. Diretrizes para UI design na HRI 52

5 Delineamento de Pesquisa 56

5.1. Tema 56

5.2. Problema 56

5.3. Hipótese $\quad 57$

5.4. Variáveis $\quad 57$

5.5. Objeto 57

5.6. Objetivos 58

5.6.1. Objetivo Geral 58

5.6.2. Objetivos Específicos 58

5.7. Justificativa $\quad 58$ 
6 Métodos, técnicas e procedimentos $\quad 60$

6.1. Entrevistas Contextuais 61

6.1.1. Sujeitos da Entrevista 62

6.1.2. Procedimento de Entrevistas 62

6.1.2.1. Planejamento 62

6.1.2.2. Execução 63

6.1.2.3. Interpretação 64

6.1.3. Coleta e análise de dados 66

$\begin{array}{ll}\text { 6.2. Testes de Usabilidade } & 67\end{array}$

6.2.1. Proposta e objetivos 68

6.2.2. Questões do Teste 68

6.2.3. Características dos participantes $\quad 69$

6.2.4. Método do Teste $\quad 70$

6.2.5. Sobre o EMMA 70

6.2.6. Lista de tarefas $\quad 72$

6.2.6.1. Tarefa de parâmetros do ambiente operacional 72

6.2.6.2. Tarefa de exame de dano da pá 74

6.2.6.3. Tarefa de Posicionamento $\quad 77$

6.2.6.4. Tarefa de Calibração 79

6.2.6.5. Simulação 79

6.2.7. Procedimento do Teste 80

6.2.8. Ambiente e equipamentos do teste 81

6.2.9. Dados coletados 82

$\begin{array}{ll}\text { 6.2.10. Teste Piloto } & 84\end{array}$

$\begin{array}{ll}7 \text { Resultados } & 86\end{array}$

7.1. Análise dos Resultados das Entrevistas Contextuais 86

$\begin{array}{ll}\text { 7.1.1. Robôs da pesquisa } & 87\end{array}$

7.1.2. Falhas na interação com robôs 95

7.2. Análise dos Resultados dos testes de usabilidade 99

8 Conclusão 105

9 Referências bibliográficas $\quad 109$ 
Apêndice A - Termo de Consentimento das Entrevistas Contextuais 114

Apêndice B - Termo de Consentimento dos Testes de Usabilidade 116

Apêndice C - Perguntas das Entrevistas Contextuais 118

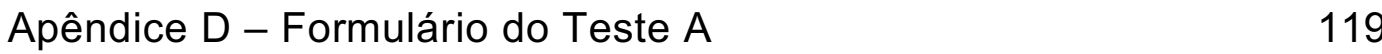

Apêndice E - Formulário do Teste B 120

Apêndice F - Interfaces do Teste A 121

Apêndice G - Interfaces do Teste B 124

Apêndice H - Tratamento dos Resultados do SUS 128 


\section{Lista de figuras}

Figura 2.1 - Evolução temporal da pesquisa robótica em relação a robôs de serviço. Fonte: Garcia, 2007........................................................... 18 Figura 2.2 - Robô Roomba. Fonte: iRobot (http://www.irobot.com/)....... 20 Figura 2.3 - DJI Phantom. Fonte: DJI (https://www.dji.com/)................. 20 Figura 2.4 - RUI desenvolvida com a biblioteca Gazebo. Fonte: J de Robot

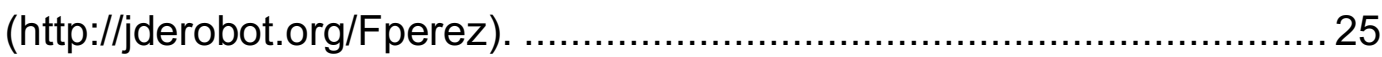

Figura 2.5 - RUI desenvolvida com Qt. Fonte: Mineo, 2015 .................. 26

Figura 3.1 - Diagrama de funções genéricas do controle de supervisão.

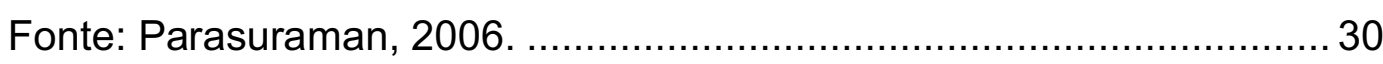
Figura 3.2 - OODA LOOP. Fonte: Dos autores, baseadas em Thomas

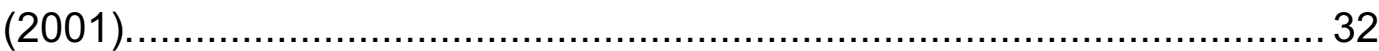

Figura 3.3 - Esquema de como riscos geram acidentes (ISO 26262)..... 33

Figura 4.1 - RUI de robô móvel que oferece visualização de um mapa do ambiente de contato direto na interface. Fonte: (https://hackaday.io/project/8588-diy-autonomous-mobile-robot)............ 46 Figura 4.2 - Usuário indica direção na tela onde robô deve se dirigir. (Fonte: https://www.wired.com/2014/10/irobot-android-app/) 48

Figura 6.1 - Usuário do robô Luma durante a execução da entrevista contextual. 64

Figura 6.2 - Notas de capturadas ao fim de sessões de interpretação de acordo com o foco de cada participante. 65

Figura 6.3 - Apresentação do aplicativo com informação sobre o sistema e suas tarefas 71

Figura 6.4 - Tela do aplicativo explicativa das partes que compõem o sistema EMMA.

Figura 6.5 - Tela do aplicativo com informações sobre as tarefas a serem executadas. 72

Figura 6.6 - Interface da tarefa 1 no Teste A, sem diretrizes para RUIs. 73 Figura 6.7 -Interface da tarefa 1 no Teste B, com diretrizes para RUls. . 74 Figura 6.8 - Primeira tela da tarefa 2 era a mesma em ambos os testes. 75 Figura 6.9 - Segunda tela da tarefa 2 no Teste A. 
Figura 6.10 - Segunda tela da tarefa 2 no Teste B.

Figura 6.11 - Ambiente de teste com uma representação do ambiente operacional em escala e posicionado a frente do participante 77

Figura 6.12 - Tela da tarefa $3 \mathrm{com}$ informações para posicionamento dos elementos da operação. 78

Figura 7.1 - Um dos entrevistados, e usuário do robô Dóris, em ambiente do laboratório LEAD da UFRJ 89 Figura 7.2 - Usuário do robô Roomba no ambiente do laboratório LEAD da UFRJ. 90

Figura 7.3 - Usuário Garra robótica no ambiente do laboratório LEAD da UFRJ 91

Figura 7.4 - RUI do robô Dóris durante a entrevista no ambiente do laboratório LEAD da UFRJ. 92

Figura 7.5 - RUI do robô Luma durante a entrevista no ambiente do laboratório LEAD da UFRJ 94

Figura 7.6 - RUI do DJI durante a entrevista em ambiente externo. 95

Figura 7.7 - Ambiente de teste com representação física da operação a frente do participante. 


\section{Lista de quadros}

Quadro 4.1 - Relação do princípio da HRI (Goodrich and Olsen, 2003) 'mudança de modo implícita' com princípios de design de Jordan (1998), Schneiderman (1998) e Nielsen (1994).

Quadro 4.2 - Relação do princípio da IHR (Goodrich and Olsen, 2003) 'uso de pistas naturais' com princípios de design de Jordan (1998), Schneiderman (1998) e Nielsen (1994).com princípios de design. $\quad 45$ Quadro 4.3 - Relação do princípio da IHR (Goodrich and Olsen, 2003) 'manipular o mundo de forma direta' com princípios de design de Jordan (1998), Schneiderman (1998) e Nielsen (1994).com princípios de design.

Quadro 4.4 - Relação do princípio da IHR (Goodrich and Olsen, 2003) 'manipular a relação entre o e o robô' com princípios de design de Jordan (1998), Schneiderman (1998) e Nielsen (1994) com princípios de design.

Quadro 4.5 - Relação do princípio da IHR (Goodrich and Olsen, 2003) 'facilitar a manipulação de informação' com princípios de design de Jordan (1998), Schneiderman (1998) e Nielsen (1994).com princípios de design.

Quadro 4.6 - Relação do princípio de HRI (Goodrich and Olsen, 2003) 'externalizar memória' com princípios de design de design de Jordan (1998), Schneiderman (1998) e Nielsen (1994).

Quadro 4.7 - Relação do princípio da HRI (Goodrich and Olsen, 2003) 'gerenciamento de atenção' com princípios de design de design de Jordan (1998), Schneiderman (1998) e Nielsen (1994).

Quadro 4.8 - Diretrizes de design de interfaces na HRI relativas ao fator humano de confiança.

Quadro 4.9 - Diretrizes de design de interfaces na HRI relativas ao fator humano de consciência situacional.

Quadro 4.10 - Diretrizes de design de interfaces na HRI relativas ao fator humano de carga de trabalho. 
Quadro 6.1 - Descrição do procedimento de execução das entrevistas contextuais.

Quadro 7.1 - Problemas de interação recorrentes observadas durante as entrevistas.

Quadro 7.2 - Relação de falhas relatadas nas entrevistas com modelagem de erros e diretrizes de design. 


\section{Lista de tabelas}

Tabela 6.1 - Procedimento par resultados do questionário SUS. $\quad 84$

Tabela 7.1 - Incidência e tipos de erros. 100

Tabela 7.2 - Tabela da Tarefa 1.

Tabela 7.3 - Desempenho dos participantes na Tarefa 2. 


\section{1 Introdução}

Nossa ideia primordial em relação a robôs é que eles existem para tornar nosso trabalho mais fácil. Por isso, a demanda por sua utilização nos mais variados campos de atuação do trabalho é muito grande. A robótica de serviço (service robotics) está voltada exatamente para a criação de robôs que de alguma forma, auxiliam humanos em suas interações sociais do dia a dia. Os robôs de serviço ajudam humanos em tarefas desde as mais complexas até as mais simples. Quem não conhece o Roomba da iRobot? Aquele robozinho redondo que fica passeando pela casa e limpando pisos de forma autônoma. Este estudo está voltado para o conhecimento e aplicação do design de interfaces neste tipo de robôs, ou seja, em robôs que nos prestam serviços: seja a manutenção de turbinas in Situ ou a limpeza do chão de nossas casas. Para isso, a pesquisa aborda o comportamento humano observado na interação com estes robôs e também diretrizes de design que abordam tal comportamento na prevenção de erros.

O objetivo geral desta dissertação é o de avaliar diretrizes específicas para o design de RUI's (Robot User Interfaces). A pesquisa vai explorar o contexto de desenvolvimento destas interfaces de usuário que permitem controle ou auxiliam na interação com robôs e sistemas autônomos de maneira geral. Ao investigar a utilização de robôs de serviço, buscará: apresentar o recorte teórico acerca de RUIs; elencar diretrizes de design pertinentes a interação com robôs e sistemas autônomos; explicar modelos de interação relacionados a robôs e suas falhas operacionais expostas em literatura; realizar entrevistas contextuais com usuários de robôs para compreender seu contexto de uso; buscar relação entre falhas de interação com diretrizes de RUI's e finalmente, testar e validar estas diretrizes de design.

Nos últimos anos os carros autônomos da Google foram capazes de rodar milhares de quilômetros em estradas americanas, assim como o robô com Watson da IBM derrotou os melhores jogadores humanos do jogo de auditório Jeopardy! Robôs representam grande marco do desenvolvimento das tecnologias digitais, no 
futuro, com os avanços em hardware, software e redes de conexão, serão capazes de aplicar enorme número de dados a realização de tarefas antes consideradas exclusivamente humanas. Este panorama futuro nos parece incerto, novas tecnologias podem tanto trazer salvação econômica ou ameaçar nossa subsistência. No entanto, a riqueza possível no trabalho com máquinas depende de encontrarmos formas de entrar para a corrida com a máquina, e não contra ela. Isso significa que nós, humanos, precisamos construir máquinas que sejam fáceis de dominar e usar, e esta pesquisa entende que o design é ferramenta essencial para que possamos nos beneficiar dessas tecnologias.

A hipótese de pesquisa parte do princípio de que para atender de forma satisfatória ao design de RUI's é preciso antes, analisar os princípios e características que consideram de forma ampla os fatores humanos relacionados a interação humano máquina. Desta forma, tem caráter exploratório, onde através de uma combinação de observações, obtém-se um conjunto de conjecturas, que por meio de testes de usabilidade, sejam refutadas ou não. A pesquisa exploratória objetiva aumentar a familiaridade do pesquisador com o tema e possibilita a análise das questões que compõem a problemática do estudo.

Os métodos utilizados nesta dissertação foram: pesquisa bibliográfica; entrevistas contextuais e testes de usabilidade. A pesquisa bibliográfica foi realizada com intuito de criar embasamento teórico acerca do tema das RUIs. Seu objetivo foi o de compreender modelos relativos à interação com robôs no trabalho remoto. Posteriormente, a análise de conteúdo foi voltada para princípios e diretrizes de design pertinentes à interação com robôs, para testar sua eficácia e eficiência em relação a falhas na realização de tarefas. Subsequentemente, utilizouse a técnica de entrevista semiestruturada, seguindo as diretrizes de uma inquirição contextual (Holtzblat, 2004); método que constituiu a abordagem de usuários de robôs de serviço em contexto, para observar os processos de trabalho, atividades e problemas na interação com sistemas e suas interfaces. Por fim, a construção do teste de usabilidade deu-se a partir do cruzamento da análise do conteúdo da pesquisa bibliográfica com as informações obtidas nas inquirições contextuais, permitindo assim, que a hipótese de pesquisa pudesse ser provada ou não.

O Capítulo 2 identifica o recorte da pesquisa e seu referencial teórico, ao explicar o conceito de robôs de serviço, sua crescente utilização em trabalho coordenado com humanos, e como suas interfaces de usuários possibilitam uma 
análise sob a perspectiva da usabilidade. Em sua explanação, fala também de sistemas robóticos e de características do desenvolvimento de software moderno, que permite avanços significativos em pouco tempo. As bibliotecas virtuais de conteúdo aberto na internet, também conhecidas como opensource, permitem que desenvolvedores contribuam exponencialmente para a melhoria e padronização de conteúdo, influenciando tanto a apresentação visual de RUI's quanto em suas limitações gráficas. O desenvolvimento de tecnologia robótica, repete assim, a história da computação, onde uma vez que um sistema operacional padrão, juntamente com ferramentas de programação de baixo custo e fáceis de usar, ficam disponível, uma explosão de software de aplicativos se consolida. Posteriormente, é descrito este contexto de desenvolvimento, como RUI's caracterizam um nicho específico da atuação de designers, e as vantagens e desvantagens nesse cenário. De maneira geral, RUI's têm como objetivo principal facilitar uma interação eficiente com robôs, auxiliando o humano na realização de atividades com máquinas. Por isso, são importantes na investigação de técnicas para a transferência de informação humanos e robôs, projetando interfaces eficazes no controle de sistemas.

O Capítulo 3 expõem a literatura sobre Interação Humano-Máquina (IHM), mais especificamente, sobre a Interação Humano-Automação (IHA) e Interação Humano-Robô (IHR), esclarecendo a relação entre modelos e as características que contribuíram para referencial teórico desta dissertação. Parte importante desta explanação se dá na descrição do trabalho coordenado com máquinas. O paradigma do controle de supervisão descrito, tipifica o papel do operador enquanto supervisor de um sistema autônomo, ilustrando as características do comportamento humano ao delegar a máquina a função operacional de uma tarefa. $O$ controle de supervisão nos mostra também, um esquema conhecido como OODA LOOP (Thomas, 2001 apud Gikkas 2013) que descreve ações cognitivas e motoras necessárias na tomada de decisões e ações durante a interação com automação. Este esquema aborda aspectos referentes ao usuário, como experiências prévias, aspectos culturais, canais de atenção, dentre outros, sendo crucial importante análise das especificidades a serem abordadas em RUI's.

No Capítulo 4, a pesquisa apresenta uma contextualização da literatura sobre regras de design de interfaces e sua relação com os fatores humanos observados na utilização de robôs. Assim, elenca os princípios e diretrizes de usabilidade que são 
relevantes a interação com robôs, realizando uma análise que permite a classificação destas regras dentro dos princípios estabelecidos pela IHR para construção de interfaces eficientes. Este capítulo conclui a base teórica da dissertação, fazendo o encaixe da conjectura estabelecida na análise de diretrizes de design com os modelos e interação investigados.

No Capítulo 5, tem-se o delineamento da pesquisa, com intuito de apresentar o desenvolvimento do problema relativo a verificação empírica, além da hipótese da pesquisa e a suas variáveis. Nele encontra-se a explicação dos elementos da dissertação: tema, problema de pesquisa, objetivo geral, objetivos específicos, hipótese, e metodologia abordada. Para examinar o problema e verificar a validade da hipótese, na seção seguinte, "Método, técnicas e procedimentos da pesquisa" (Capítulo 6), são descritos os métodos e técnicas da pesquisa, assim como a justificativa para sua escolha e as formas com que objetivos específicos foram executados. Como parte da investigação do problema, a metodologia utilizada observou os usuários de robôs e os contextos de uso através de entrevistas contextuais, para posteriormente relacioná-las à diretrizes de usabilidade do design de interfaces consolidadas na pesquisa. Subsequentemente às falhas encontradas na literatura e nas entrevistas contextuais, iniciaram-se os testes de usabilidade. Os testes de usabilidade tinham o objetivo de confirmar da hipótese da pesquisa: de que se RUI's forem concebidas considerando as especificidades de seu modelo de interação as falhas operacionais serão reduzidas na interação.

No Capítulo 7, os resultados desse estudo foram tratados individualmente e, em análise posterior, paralelo e comparativamente (Subcapítulos 7.1 e 7.2). Por fim, no Capítulo 8, foram apresentadas as conclusões acerca da dissertação como um todo, defendida a comprovação da hipótese e explicitados os potenciais desdobramentos da pesquisa, seguidos pela seção de "Referências Bibliográficas" (Capítulo 8) e os Apêndices. 


\section{2 \\ Sobre sistemas robóticos e o desenvolvimento de GUls ${ }^{1}$}

A mitologia está repleta de seres artificiais e, ainda assim, o robô se tornou um mito na cultura moderna. Por ser um tema cercado de imaginação, sempre despertou a curiosidade do público por meio a histórias futurísticas e fantasiosas sobre a relação de seres humanos com máquinas. A origem da palavra 'robô' vem do tcheco 'robota', que significa "servidão, ou trabalho forçado". Karel Capek (1890-1938) utilizou o termo pela primeira vez em sua obra teatral "Os Robôs Universais de Rossum". A peça narra a história de trabalhadores futuristas criados pelo homem para automatizar tarefas e aliviar a carga de trabalho dos seres humanos (Niku, 2010). Estes robôs eram feitos de matéria orgânica e produzidos em uma ilha remota por pai e filho, Velho e Novo Rossum. O primeiro, pai e inventor, havia feito o plano para criar o ser perfeito que assumiria o papel do Criador, enquanto o filho enxergava os robôs apenas como parte de negócios em um mundo cada vez mais automatizado.

Ficção à parte, com o passar do tempo e com a aceleração implacável da tecnologia, a noção fantasiosa da relação humana com as máquinas começa a mudar, questionando um de nossos pressupostos mais básicos com relação a ela, de que máquinas são apenas ferramentas para aumentar a produtividade de trabalhadores. Em vez disso, as próprias máquinas estão se transformando em trabalhadores, tornando a linha entre a capacidade de trabalho e o capital mais tênue do que nunca. E, é claro, esse progresso impulsionado pela revolução tecnológica e o crescimento exponencial da informática.

A tecnologia vai continuar a avançar e naturalmente deslocar empregos e influenciar o contexto socioeconômico mundial. Ao criar mais robôs, precisaremos de mais pessoas para mantê-los, para programá-los e instalá-los. A grande questão

\footnotetext{
${ }^{1}$ Parte deste texto foi publicado sob forma de artigo produzido pela autora CAMPANA, Julia Ramos; QUARESMA, Manuela. The Importance of Specific Usability Guidelines for Robot User Interfaces. In: International Conference of Design, User Experience, and Usability. Springer, Cham, 2017. p. 471-483.
} 
da evolução tecnológica é reponsabilidade de adaptar as novas tecnologias as capacidades e limitações humanas. Robôs precisam ser fáceis de usar e interagir, e o foco do trabalho coordenado não deve ser apenas o funcionamento simplesmente, mas também garantir o controle sobre onde e como eles vão trabalhar.

\section{1.}

\section{A robótica de serviço}

$\mathrm{Na}$ atualidade, a maioria das pessoas na cultura ocidental ainda acredita no ideal vitoriano de progresso. Esse ideal nos remete a um padrão de mudança na história da humanidade, onde mudanças irreversíveis acontecem em apenas uma direção, e que essa direção, é sempre a melhor (Pollard, 1968). Nossa cultura tecnológica mede o progresso pelo avanço tecnológico, e nossa ideia de progresso material está intrinsecamente ligada à ciência e à indústria. Neste contexto, robôs são vistos como representantes de nossa capacidade tecnológica, pois viraram uma grande referência em nossa evolução enquanto civilização. Com a introdução de robôs automatizados na indústria automobilística, a robótica evoluiu para o desenvolvimento de sistemas que auxiliam o trabalho humano. Consequentemente, o aumento de complexidade nas tarefas executadas por robôs criou áreas de pesquisa voltadas para sistemas adaptativos e inteligentes, que simbolizam nosso avanço tecnológico.

De acordo com Garcia (2007), desde que a robótica industrial desvencilhou o operador humano de riscos e tarefas perigosas no ambiente de trabalho, houve uma crescente explosão na pesquisa relacionada a robôs para executar as mais variadas tarefas. Esta tendência delineou a robótica de serviços, (service robotics) que tem como objetivo geral, auxiliar humanos em suas interações sociais cotidianas. A robótica de serviço (Figura 2.1), engloba uma ampla variedade de robôs, desde robôs manipuladores, robôs que atuam em âmbito industrial, robôs móveis para fins de resgate ou para fins cirúrgicos, em diferentes tipos de trabalho. Estes robôs saíram do ambiente puramente industrial para mostrar que a automação também vai modelar a mão-de obra e a prestação de serviços num futuro próximo.

De fato, a mudança com relação à mão de obra parece inevitável com avanço da inteligência artificial e a crescente proficiência de computadores em adquirir 
habilidades com técnicas de machine learning ${ }^{2}$ e deep learning ${ }^{3}$. Estas técnicas de aprendizado de máquinas começam a automatizar não só trabalhos que exigem pouca habilidade ou conhecimento, mas também trabalhos mais complexos como, por exemplo, o de um assessor jurídico (Brynjolfsson, 2016). Estas mudanças atingem diretamente setores da indústria ligados à manufatura e à produção têxtil onde grande parte destes trabalhadores é empregada, sugerindo uma transição que já dá indícios grande estresse na economia e sociedade (Ford, 2015).

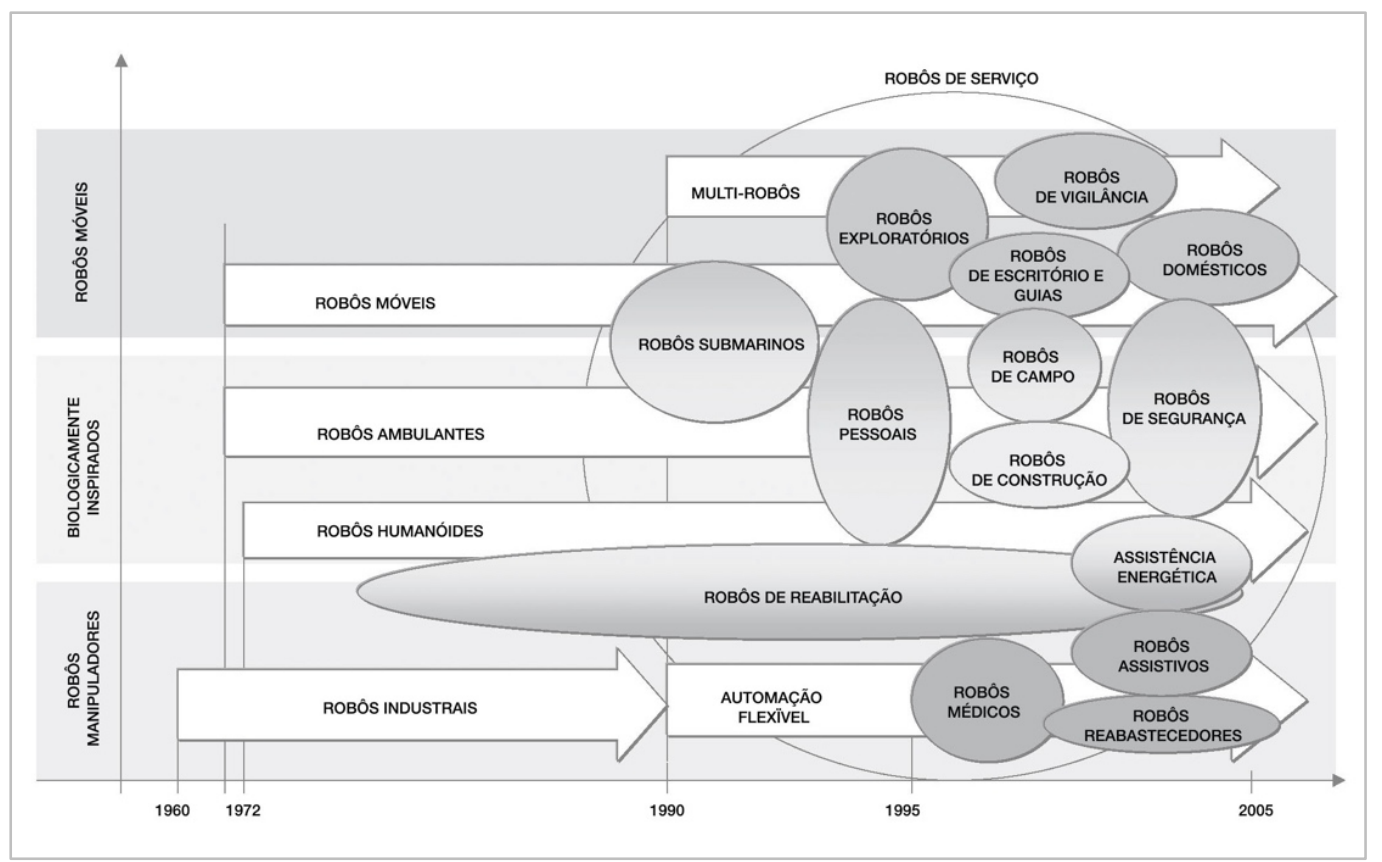

Figura 2.1 - Evolução temporal da pesquisa robótica em relação a robôs de serviço. Fonte: Garcia, 2007.

O robô $\mathrm{O}$ robô de serviço é um termo genérico que abrange todos os robôs que prestam serviços úteis para o bem-estar dos seres humanos tais como: manutenção e reparos em ambientes perigosos, cuidado com idosos, limpeza, exploração espacial dentre outros. A Figura 2.1 nos mostra a amplitude do que pode ser considerado robótica de serviço, segundo Garcia (2007); atividades que variam desde o âmbito de indústrias até seus serviços e contextos. $\mathrm{O}$ desenvolvimento e a operação destes robôs fornecem uma experiência inestimável, pois permitem um

${ }^{2}$ Machine learning ou aprendizagem de máquinas são sistemas usados para identificar objetos em imagens, transcrever discursos para texto, combinar itens ou selecionar resultados de pesquisa com intuito de dar significado a grandes volumes de dados. Essas aplicações utilizam uma clássica de técnicas chamada deep learning ou aprendizagem profunda.

${ }^{3}$ Deep learning em português, aprendizagem profunda, permite modelos computacionais que compõem múltiplas camadas de processamento aprender representações de dados com múltiplos níveis de abstração. 
estágio intermediário na evolução do robô industrial para o robô pessoal. Ademais, umas das áreas da robótica de serviço que desponta como precursora de inovações é a robótica pessoal (personal robotics). É esta área da robótica que nos permite interagir com o que existe de mais avançado na utilização de técnicas de programação relacionadas à inteligência artificial e machine learning.

Robôs não são novidades em fábricas e plantas industriais, eles se tornaram trabalhadores versáteis, indispensáveis em basicamente todo setor de manufatura desde a indústria automobilística até semicondutores. Essas máquinas são capazes executar tarefas autônomas com destreza. De acordo com a Federação Internacional de Robótica, os embarques globais de robôs industriais aumentaram em mais de $60 \%$ entre 2000 e 2012, com vendas totais de cerca de 28 bilhões em 2012 (Ford, 2015). Os novos tipos de robôs buscam um alto nível de inteligência, funcionalidade, flexibilidade, adaptabilidade, mobilidade e eficiência para executar trabalhos variados. De acordo com Habib (2006), os pré-requisitos cruciais para a realização de serviços robóticos são segurança, mobilidade e autonomia, apoiados pela forte percepção sensorial. Estes robôs devem ser bons no que podem fazer, e ter a capacidade de trabalhar em um maior grau de ambientes não estruturados. Alinhado esses pré-requisitos, estudos relacionados a IHR desempenham papel crucial na pesquisa e desenvolvimento de robôs pessoais inteligentes.

No outro espectro de atuação dos robôs de serviço, que requerem programação complexa e custosa, uma nova geração de robôs menores e poderosos emergiu com força. Robôs como o Roomba (Figura 2), da iRobot, limpador autônomo ou o Drone DJI (Figura 3), são robôs que já estão dentro de nossas casas. Estes robôs são desenvolvidos para usuários finais comuns, sem a necessidade de um conhecimento mais técnico para seu uso, quem sincroniza suas funcionalidades com nossos dispositivos móveis emprestando sua usabilidade e tornando-se ferramentas fáceis e práticas de serem usadas, seja na limpeza da casa, seja ou na visualização de esportes radicais. 


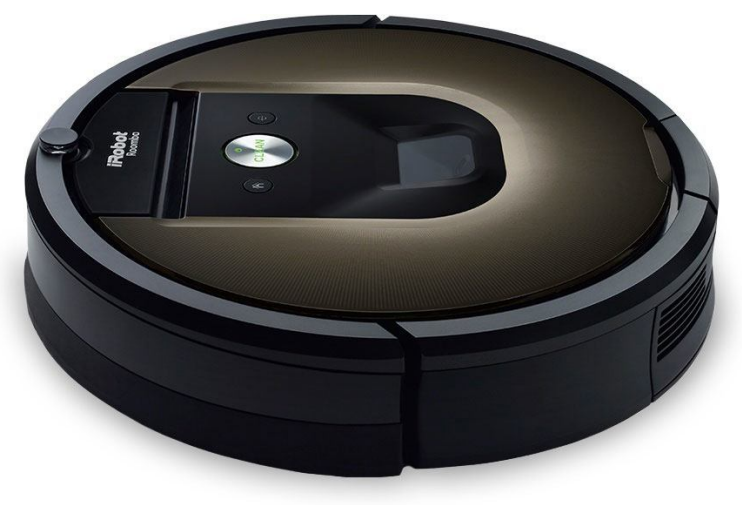

Figura 2.2 - Robô Roomba. Fonte: iRobot (http://www.irobot.com/).

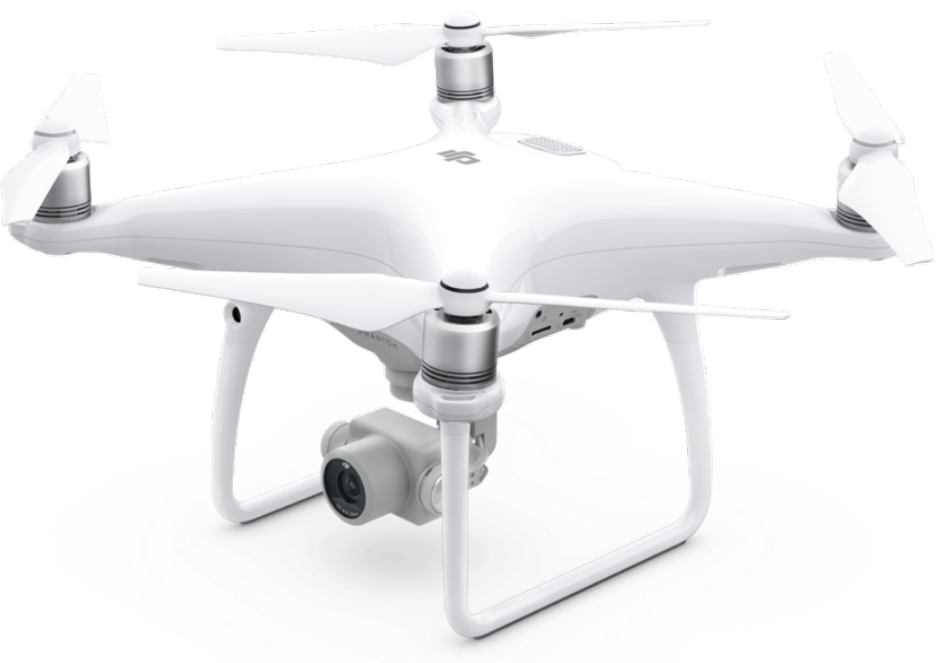

Figura 2.3 - DJI Phantom. Fonte: DJI (https://www.dji.com/).

O robô Watson da IBM se tornou um marco na evolução dos robôs ao derrotar seus concorrentes humanos no show de perguntas Joepardy ${ }^{4}$. Outro robô, o Deep Blue da IBM, capaz de processar mais de 200 posições por segundo, já havia sido capaz de derrotar um humano antes, o astro do xadrez Garry Kasparov, em 1996 (Ford, 2015). O que impressiona na vitória de Watson não é seu poder de processamento matemático, e sim sua capacidade de criar contexto através de interpretação de texto, diálogo, diferentes linguagens e reconhecimento visual. Já o robô Baxter, criado pela Rethink Robotics, tem aparência humanoide e custa significativamente menos que o salario anual de um trabalhador de fábricas americanas (Brynjolfsson, 2016). O robô pode ser facilmente treinado através de

\footnotetext{
${ }^{4}$ Jeopardy é um programa da televisão americana atualmente exibido pela CBS Television Distribuition. É um show de perguntas e respostas variando história, literatura, cultura e ciências.
} 
machine learning para realizar tarefas repetitivas. Baxter é basicamente um sinal dos tempos, isto é, um robô de serviço de baixo custo que oferece programação avançada e opera de forma segura perto das pessoas.

De fato, o avanço tecnológico vai continuar criando novos robôs que não só nos servirão, mas também vão mudar significantemente o contexto do setor de serviços e mão de obra. O interessante na investigação voltada a robôs de serviço é proporcionar uma observação ampla das regras de suas GUIs (Graphical User Interfaces ou interfaces gráficas de usuário) já que são abordados robôs diferentes, desde robôs móveis, robôs submarinos e terrestres, até os robôs que são vendidos em lojas de eletrônicos como Roomba e o DJI.

\section{2 . \\ Sistemas robóticos de controle de máquina In Situ}

Esta pesquisa vai explorar robôs que se enquadram na categoria de robôs de serviço como robôs industriais inseridos em soluções robóticas. Ou seja, esses robôs são parte de um sistema robótico, e sua finalidade de automação se integra a uma solução customizada para resolver determinado problema. Robôs industriais dependem principalmente de posicionamento e tempo precisos, oferecendo uma combinação incomparável de velocidade, precisão e força bruta em relação ao ser humano. No entanto, na maior parte, ainda são atores cegos em uma coreografia precisa, onde podem ver apenas duas dimensões em condições de iluminação controladas. Eles podem, por exemplo, selecionar peças de uma superfície plana, mas a incapacidade de perceber a profundidade em seu campo de visão resulta em uma baixa tolerância para ambientes imprevisíveis. (Ford, 2015).

Ainda existe uma lacuna a ser preenchida quando pensamos em integrar robôs com fluidez a trabalhos customizados no âmbito nacional. A importância de explorar questões ligadas à interação e ao comportamento humano na interação com robôs, que podem otimizar estruturas e trabalhos de uma forma geral, representa grande impulso na pesquisa e desenvolvimento da tecnologia no Brasil. Esses projetos inseridos no contexto de pesquisa e desenvolvimento (P\&D), fomentados pela reinvestimento do lucro de setores de energia, como óleo e gás e o setor hidroelétrico, trazem a possibilidade da criação de patentes e novas tecnologias para o país. Por isso, além da exploração de sistemas de robôs de serviço, esta pesquisa 
vai explorar a usabilidade de sistemas robóticos que se destinam ao controle de máquinas in situ ${ }^{5}$, ou seja, que operam de forma remota em ambientes perigosos. Desta forma, se estabelece um contexto clássico da função robótica, que executa uma função complexa e perigosa, para executar uma tarefa que não pode ser feita por um ser humano.

\section{3. \\ Sistema operacional robótico}

De acordo com Craig (2005), para funcionar, um robô requer um espaço de trabalho, uma fonte de energia, um computador, uma fonte de informação programada por um humano - que vai definir o trabalho a ser feito em tempo real ou não, independentemente se de forma autônoma ou em modo cooperativo. A estrutura de controle está na unidade de processamento central e operacional do robô onde estão as funcionalidades do sistema, que distribui sinais com informações de saída usando os dados de entrada. Essa informação sob forma de dados se enquadra em três categorias. (a) instruções: definem a tarefa a ser executada (por exemplo, comando e objetivos); (b) medições relativas ao estado da unidade operacional; (c) observações sobre o espaço de trabalho (Parasuraman e Sheridan, 2006). Sua representação física ou gráfica é onde o usuário pode controlar o robô, por vezes chamado controle de missão e contém as informações das tarefas a serem executadas e seu funcionamento.

Para além de aspectos técnicos, enquanto o Roomba e o DJI são máquinas muito diferentes, ambas são construídas nos fundamentos da mesma plataforma de software chamada ROS. O ROS (Robot Operating System ou sistema operacional robótico) foi, inicialmente, projetado no Laboratório de Inteligência Artificial da Universidade de Stanford e depois desenvolvido por uma pequena empresa do Vale do Silício chamada Willow Garage, em uma plataforma robotizada completa (Ford, 2015). O sistema é semelhante a sistemas operacionais como o Microsoft Windows, o Android da Google ou o OS da Macintosh. O que diferencia o ROS dos demais, é o fato de ser voltado para a construção de robôs facilitando sua programação e controle. Por ser uma plataforma de código aberto, desenvolvedores podem

\footnotetext{
${ }^{5}$ In situ: locução adverbial. Expressão que vem do latim IN LOCO e significa (1) que está em seu lugar natural ou normal (diz-se de estrutura ou órgão). (2) que permanece confinado ao local de origem sem invadir.
} 
facilmente modificá-lo e refiná-lo, tornando-o rapidamente uma plataforma padrão no desenvolvimento de robôs.

A julgar pelo desenvolvimento da web e aplicativos em plataformas abertas, a história da computação mostra claramente que uma vez que um sistema operacional padrão, junto com ferramentas de programação baratas e fáceis de usar, fica disponível, uma explosão de softwares aplicativos acompanha o movimento (Brynjolfsson, 2016). A plataforma ROS funciona com uma coleção de estruturas ou frameworks de software, fornecendo funcionalidade de um sistema operacional a vários computadores diferentes e possivelmente interligados. Similar a outras plataformas de desenvolvimento, sua característica agregadora também favorece a criação de pacotes para a visualização de seus controles e eventuais GUIs.

\section{4 . GUls na robótica}

A literatura apresenta o termo Robot User interface (RUI) para designar interfaces de usuários específicas para robôs que permitam acesso remoto ou virtual de operadores ao trabalho em ambientes complexos (Naveed, 2014). De maneira geral, a forma mais comum de comunicação indireta com um robô é feita pelo uso de algum tipo de controle remoto (Clarkson, 2007). No entanto, isto vem mudando à medida que novas formas de interfaces de usuário entre humanos e robôs são desenvolvidas. Esta mudança confere à usabilidade uma importante função no design de interfaces destes sistemas, sendo a investigação de suas regras um importante passo para melhores interações.

No que se refere às RUIs abordadas nesta dissertação, dois aspectos são relevantes na análise. O primeiro é o fato de que plataformas de desenvolvimento abertas incentivam a criação de estruturas de desenvolvimento visualmente padronizadas. O segundo é o fator tecnologia, que naturalmente substitui equipamentos tradicionais de interface com robôs como joysticks e painéis por uma nova geração de dispositivos com feedback visual e de mobilidade mais apurados, como tablets e smartphones (Kawamura, 2001). O avanço em aplicações robotizadas criou necessidade de interface com diferentes partes de soluções integradas em ambientes virtuais. 
De maneira geral, RUIs são desenvolvidas para desempenhar um papel importante no controle de robôs e na garantia de segurança em ambientes complexos. Em um primeiro momento, RUIs podem ser difíceis de compreender, já que exigem treinamento de operadores e apresentam características específicas de um dado sistema ou serviço. Outro aspecto determinante em sua produção é o resultado da ausência da função de designer em equipes, muitas vezes resultando em interfaces projetadas e desenvolvidas pelos mesmos indivíduos que constroem o robô (Naveed, 2014). RUIs são geralmente refinadas em pesquisa e desenvolvimento aplicados, o que implica um caráter distinto em termos de aplicação e produção de design.

No entanto, mais recentemente o desenvolvimento de software com base em plataformas de código aberto fez com que o resultado visual destas interfaces ganhasse forma sob as mesmas noções estruturais de desenvolvimento para dispositivos móveis. Um bom exemplo desta padronização pode ser o Bootstrap, um conjunto de ferramentas para desenvolvimento na web com as linguagens de HTML, CSS e JavaScript que permite que se crie rapidamente protótipos ou aplicativos a partir de uma biblioteca de componentes pré-existentes e uma infinidade de plug-ins. Dentro do contexto de desenvolvimento, para robótica e analogamente à web, bibliotecas como Gazebo e Qt permitem integração com ROS para o desenvolvimento de RUIs padronizadas. O Gazebo (Figura 2.4) é uma biblioteca com diferentes modelos de simulação e aplicações robóticas com capacidade de simular populações de robôs em ambientes internos e externos complexos de forma precisa. A ferramenta permite realizar testes rápidos, projetar robôs, e treinar o sistema de inteligência artificial (IA) usando cenários realistas. 


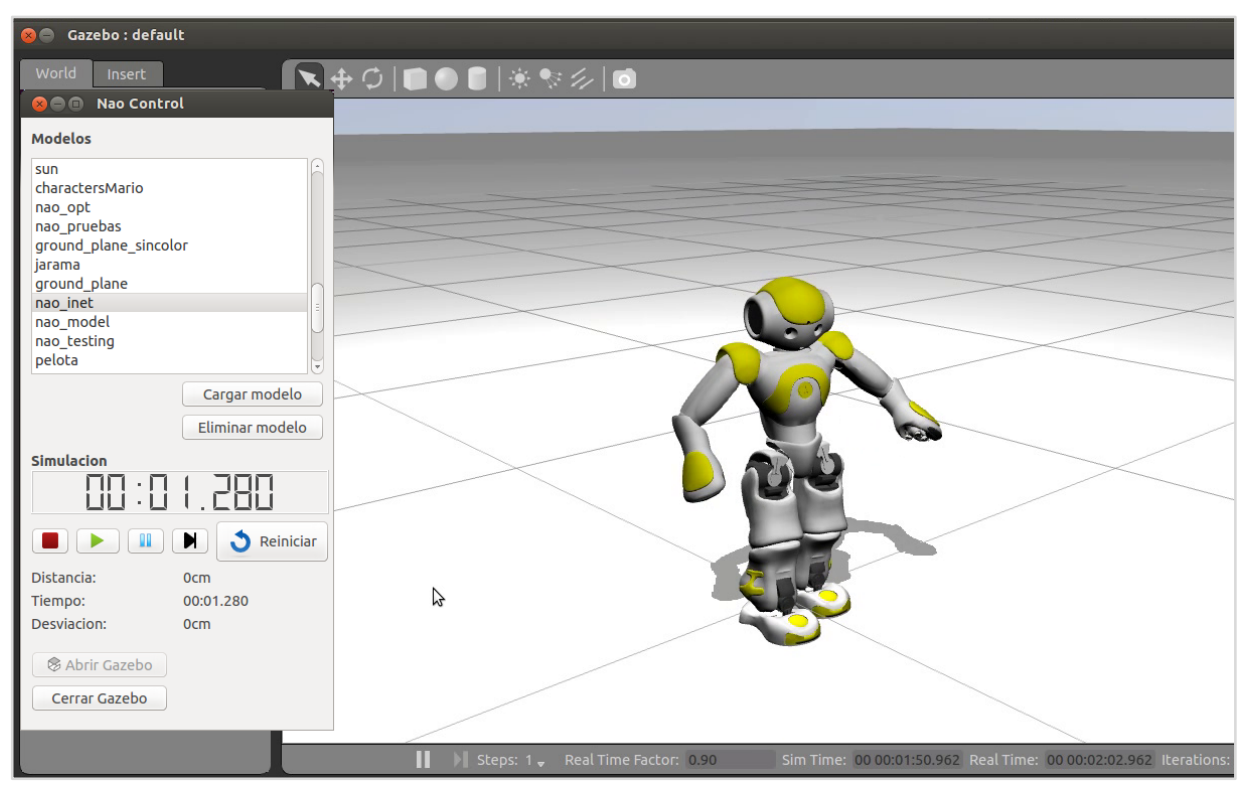

Figura 2.4 - RUI desenvolvida com a biblioteca Gazebo. Fonte: J de Robot (http://jderobot.org/Fperez).

O Qt é um kit de desenvolvimento de software (Software Development Kit, SDK), que funciona como uma plataforma mista, permitindo que desenvolvedores projetem, desenvolvam, implementem e mantenham software de forma rápida e econômica, que permite alcance a todos os dispositivos. Para isso, viabiliza aplicações e dispositivos embutidos, intuitivos e de alto desempenho - com a mesma base de código para todas as plataformas em qualquer sistema operacional a qualquer momento. O Qt Creator é um IDE (Integrated Development Environment), ou ambiente de software integrado que torna o desenvolvimento de aplicativos e UI mais rápidos. Este software inclui ferramentas de produtividade que aceleram seu tempo de desenvolvimento e ajudam a projetar interfaces de usuários com amplas bibliotecas de widgets $^{6}$ e animações. (Figura 2.5)

\footnotetext{
${ }^{6}$ Widget é um componente de uma interface gráfica do usuário (GUI), o que inclui janelas, botões, menus, ícones, barras de rolagem, etc..
} 


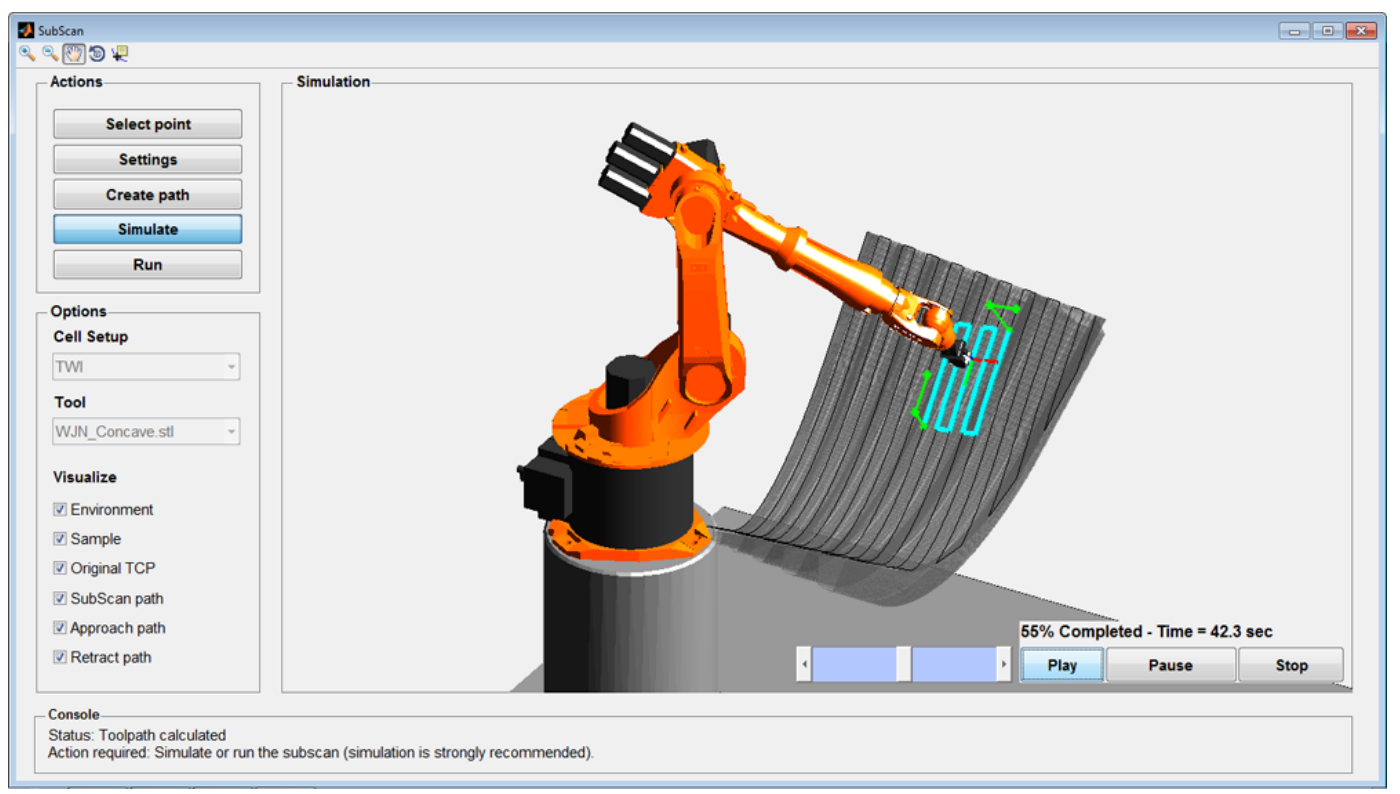

Figura 2.5 - RUI desenvolvida com Qt. Fonte: Mineo, 2015.

Ao analisar o contexto de desenvolvimento de GUIs na robótica é possível compreender a importância de pensar sua projeção de forma adequada ao usuário que irá interagir com o sistema. RUIs nada mais são do que GUIs em um contexto de uso específico, no caso, para com objetivo auxiliar e monitorar o controle de robôs de serviço. Por isso, é imprescindível que estas interfaces gráficas sejam criadas e projetadas seguindo diretrizes de design e usabilidade, que, por sua vez, foram criadas a partir do conhecimento das capacidades e limitações humanas e dentro dos seus processos cognitivos. 


\section{3 \\ Interação com sistemas automatizados e sistemas robóticos}

Para falar sobre a construção e validação de interfaces de usuários em sistemas robóticos é preciso antes é que se caracterize os modelos de interação referentes não só a robôs e humanos, mas também à computadores, e sistemas automatizados. A Interação Humano-Computador (comumente referida como HCI, human computer interaction) é um amplo campo de pesquisa que investiga o design e uso da tecnologia informática, focada nas interfaces entre pessoas (usuários) e computadores. Já a Interação Humano-Automação (HAI, human-automation interaction) está presente de forma massiva em nossos meios de produção diários, e é parte integral do trabalho coordenado com máquinas e também robôs. A medida que se interage com sistemas robóticos e automatizados o cenário de usabilidade é então, caracterizado por comportamentos de usuários que são descritos com o auxílio destes modelos.

O modelo de Interação Humano Automação (HAI) compreende a Interação Humano Robô (HRI, Human Robot Interaction) como subárea, uma vez que interação com robôs caracteriza também a interação com sistemas automatizados. Partindo do princípio que, independentemente de seu nível de autonomia, robôs são máquinas, devemos entender sistemas robóticos também como sistemas autônomos. Estes sistemas automatizados, têm por objetivo auxiliar o trabalho humano, realizando tarefas perigosas com precisão e reduzindo nosso esforço. No entanto, o trabalho de sistemas automatizados é baseado na leitura numérica de sensores em presunção de cenários. Tal presunção, torna estes mecanismos suscetíveis a erros, uma vez que computadores pensam apenas de forma numérica, desprovidos de uma interpretação semântica, que possibilite abstração para compreender a realidade.

Por isso, apesar de todo avanço tecnológico, ainda restam lacunas a serem preenchidas quando falhas ocorrem. As falhas de automação podem comprometer 
a interação com sistemas de formas distintas, sendo caracterizadas por diferentes tipos de erro. Esses erros estão ligados a fatores humanos observados no processo de planejamento e tomada de decisão na interação com sistemas automatizados. A abordagem ao comportamento do usuário a partir do paradigma estabelecido no controle de supervisão (Parasuraman, 2006) explica como o humano deixa de ser o agente principal para delegar a máquina as etapas operacionais de uma tarefa. Analogamente, este paradigma também vai auxiliar esta pesquisa ao descrever o papel de supervisor por parte do usuário, que ao monitorar operações, passa a ter que se preocupar com outros aspectos operacionais tais como atenção situacional, confiança e carga de trabalho ao monitorar o sistema.

\section{1. Modelo de Interação Humano-Automação}

Com todo o avanço tecnológico que permeia nossas vidas, a automação se faz presente de formas variadas. Hoje em dia, sistemas autônomos estão intrínsecos em serviços, atividades de lazer e muitos outros aspectos de nossas atividades cotidianas. No entanto, em muitos destes contextos, somos apenas agentes passivos de interação. No contexto de interação proposto por Sheridan e Parasuraman (2006), entende-se automação como as circunstancias em que pessoas (a) especificam a automação (necessariamente um computador de algum tipo) com metas e restrições (faça $\mathrm{X}$, mas evite fazer $\mathrm{Y}$ ) e trade-offs entre os objetivos e restrições; (b) controlam a automação para iniciar ou interromper ou modificar uma tarefa executada automaticamente; e (c) recebem informações de automação, energia, objetos físicos, ou substâncias.

As condições para que a automação se inicie, pare ou modifique sua execução podem ser, por exemplo, sensores indicando que determinado parâmetro de funcionamento foi atingido, ou mesmo, quando um robô faz contato com um objeto. Neste contexto, operadores podem interromper a execução automática e ou impor novo controle ao identificar algum problema.

Em síntese, o mais importante na compreensão do modelo de interação com sistemas automatizados é que o ser humano deixa de ser o ator principal na realização de tarefas a serem executadas. Na interação com automação, as funções operacionais são delegadas às máquinas, que, por sua vez, interpretam os dados 
relevantes para a situação avaliando seu contexto e agindo da melhor forma dentro de seus parâmetros funcionais. Assim, entende-se que o operador da máquina interage nos extremos da operação: na ativação inicial do sistema e na interpretação final dos resultados, delegando às maquinas todas as etapas de caráter operacional.

Este estudo aborda a interação com robôs de serviço e, por isso, tanto no que se refere a modelos de interação quanto à natureza dos sistemas abordados, semelhanças entre automação e robotização são estabelecidas. Automatização é um termo amplo que pode ter muitos significados dependendo do contexto em que está inserido. Nesta pesquisa, automação significa a realização de tarefas e atividades coordenadas com máquinas, sem que haja interferência humana direta no processo operacional. Para Sheridan \& Parasuraman (2006), a automatização pode ser entendida sob quatro definições: a) mecanização e integração de leituras de variáveis contextuais; b) processamento de dados e tomada de decisão por parte de computadores; c) ação mecânica que aplica força sobre determinado ambiente; d) ação informacional pela comunicação de informação processada para o usuário.

\subsubsection{Paradigma do controle de supervisão}

O papel central de humanos em sistemas que possuem automação é o de assumir o chamado controle de supervisão (Parasuraman, 2006). Esse controle estabelece uma nova relação entre humanos e máquinas à medida sua interação difere do modelo tradicional humano-tarefa-máquina, onde o homem executa uma tarefa a partir de um computador ou sistema sem inteligência. No paradigma de controle de supervisão, o homem ou operador se torna um estrategista, interagindo no início e ao final da operação, delegando à máquina todas as etapas operacionais da tarefa. 


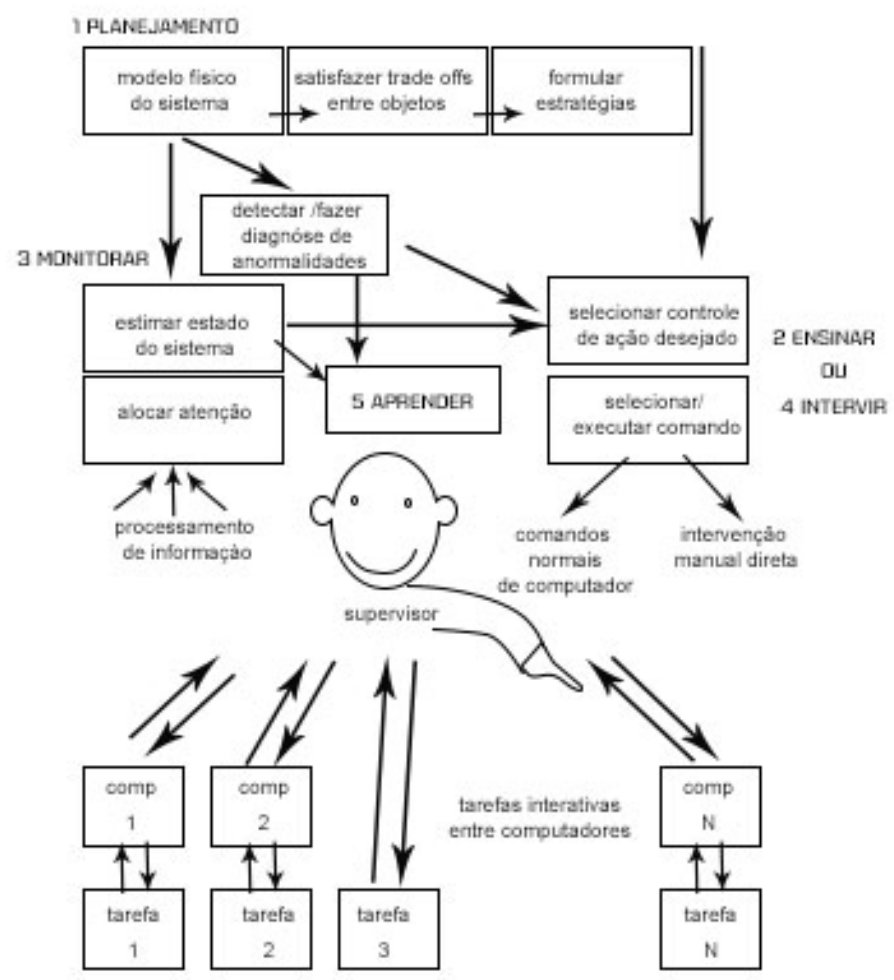

Figura 3.1 - Diagrama de funções genéricas do controle de supervisão. Fonte: Parasuraman, 2006.

A Figura 3.1 mostra que o supervisor humano pode coordenar uma ou múltiplas máquinas controladas por um computador que executa tarefas simultâneas. As várias caixas de tarefas, representam o que poderiam ser diferentes sistemas dentro de um mesmo sistema, por exemplo. Acima da figura humana são caixas que representam as cinco funções do supervisor: 1) planejamento off-line; 2) ensino da automação; 3 ) monitoramento de execução do plano de automação; 4) intervenção para interromper ou retomar o controle conforme necessário, e 5) aprendizagem com a experiência.

Para planejar, é preciso ter algum modelo mental ou computador do sistema físico a ser controlado, com algumas trocas (trade-offs) entre objetivos de desempenho que podem ser satisfeitos, além da formulação de estratégia para executar a tarefa. Para ensinar, é preciso meios para decidir sobre determinada ação de controle e comunicar comandos para implementar essa ação. Para monitorar, é preciso meios para alocar atenção entre as telas apropriadas ou outras fontes de informação sobre o progresso da tarefa e para estimar o estado atual do sistema mantendo a percepção da ação. Já intervir, significa que se uma anormalidade significativa é detectada e diagnosticada, o humano pode reprogramar a automação 
ou pode até mesmo assumir seu controle manual. Desta forma, a função do controle de supervisão de um único ou vários sistemas automatizados obedece sempre a este loop de atividades nesta mesma ordem.

\subsection{2.}

\section{OODA Loop}

OODA LOOP (Observation, Orientation, Decision, Action) (Figura 3.2) originalmente descrito por Boyd (1997) e mencionado por outros autores na literatura referente à HAI, é um esquema com uma série de ações cognitivas e motoras necessárias à um operador ou usuário para tomar decisões e executá-las durante a interação com automação. Este esquema constitui um modelo geral que envolve execução e desenvolvimento de um plano para a tomada de decisão. Para tanto, leva em consideração diferentes aspectos em relação ao usuário, como experiências anteriores, aspectos culturais, informação passada e os canais de atenção necessários (Thomas, 2001 apud Gikkas, 2013). A temperança e consideração de todas essas variáveis tornam-se essenciais durante a interação com sistemas autônomos para que o usuário possa compreender o contexto da operação e agir de forma correta diante de cada situação.

O esquema OODA LOOP é aplicado na verificação de funcionamento dos sistemas em si, apontando consideração as variáveis, aos cenários pré-determinados e as leituras dos sensores para tomada de decisão. No processo, a comunicação entre os usuários e o sistema é diretamente interligada, e por isso falhas de interpretação de sensores ou um feedback impreciso pode interferir diretamente nas ações do operador.

No referencial teórico desta pesquisa, para que se considere um cenário onde não ocorrem problemas durante a interação Humano-Automatização, é necessário que todos os 4 estágios do esquema OODA LOOP sejam contemplados de acordo com as necessidades do usuário, ou seja:1) Ele deve estar atento e habilitado a observar com clareza todos as questões referentes ao funcionamento do sistema; 2 ) ele deve ser capaz de dicernir e interpretar a informação observada de maneira a compreender o que está acontecendo; 3) uma vez ciente da situação, deve ser capaz de tomar a decisão certa de acordo com o cenário; 4) ele deve ser capaz de executar a ação planejada sem grandes dificuldades e em tempo hábil. Dentro destas 
circunstâncias, o esquema se faz assim, importante para a modelagem e caracterização dos tipos de erros na interação com sistemas automatizados.

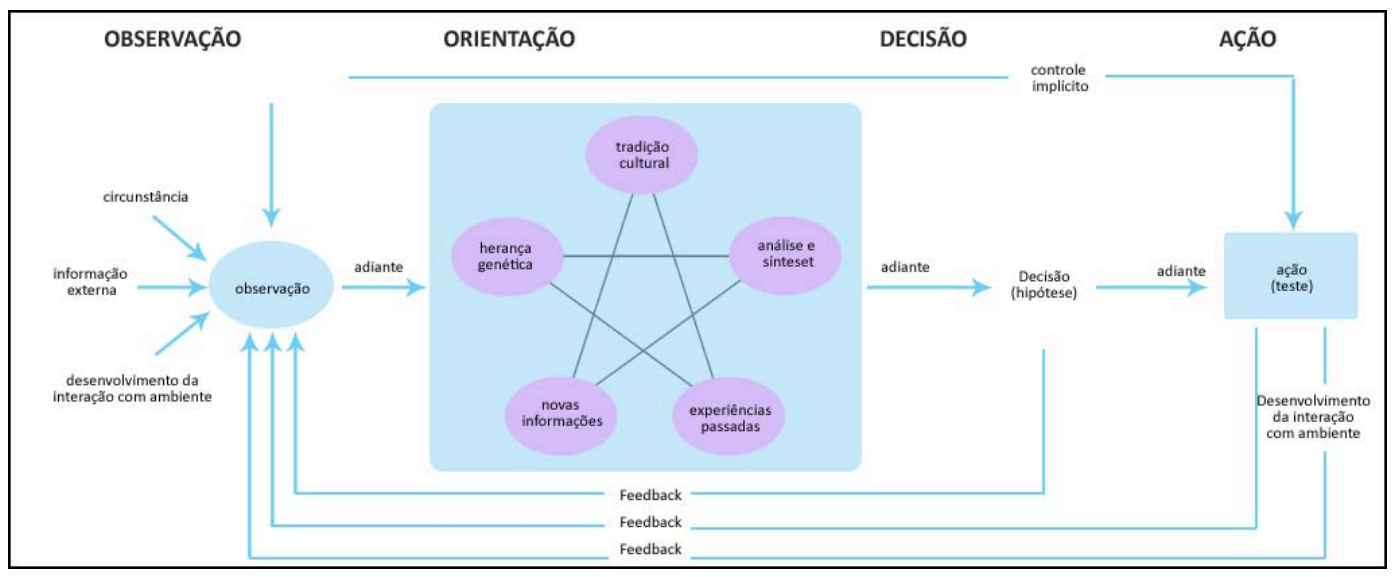

Figura 3.2 - OODA LOOP. Fonte: Dos autores, baseadas em Thomas (2001).

\subsection{3.}

\section{Falhas com Automação}

Apesar da recente capacidade de máquinas aprenderem com seus erros, muitos dos sistemas autônomos ainda não são capazes de identificar erros de forma clara durante seu funcionamento. Automação é algo que vem evoluindo, porém ainda tem um longo caminho a percorrer até que máquinas possam funcionar sem supervisão. Norman (2006) afirma que objetos são responsivos, e não inteligentes, por isso máquinas não têm como prever $100 \%$ dos casos passíveis de falhas num sistema complexo. Neste tipo de interação, a capacidade de contextualização humana estabelece um entendimento mais amplo, do qual sistemas autônomos ainda não são capazes, e por isso, mesmo delegando às máquinas as etapas operacionais de uma tarefa, o potencial de antever falhas ainda é essencial para realização bem-sucedida de tarefas com automação.

No caso da interação com RUIs, a ocorrência de falhas em muito tem a ver com a percepção da operação remota. Em ambientes de teleoperação, a percepção humana é comprometida porque o processamento perceptual natural é desacoplado do ambiente físico (Woods, Tittle, Feil e Roesler, 2004). Este desacoplamento afeta a percepção das pessoas sobre os recursos na cena remota e muitas vezes cria problemas na percepção, como a ambiguidade de escala dos elementos visualizados. Tarefas simples podem ser desafiadoras pela falta de feedback de 
movimento no processamento visual remoto e incompatibilidade de pontos de vista. Aspectos como altura diferente do padrão de altura humano podem resultar em má percepção e, consequentemente, criar um efeito negativo sobre o fator de consciência situacional humana e a controlabilidade de um sistema (Tittle, Roesler e Woods, 2002).

Gonçalves e Quaresma (2015) afirmam que máquinas são suscetíveis a falhas tanto de operação quanto de interpretação. Assim como os sistemas podem falhar, o mau planejamento das interações do sistema também pode acarretar em problemas na realização de tarefas. As falhas operacionais e de interpretação têm um impacto negativo no controle do sistema, comprometendo a interação em diferentes níveis, conforme a gravidade do problema. O esquema da figura 3.3 ilustra os principais fatores causadores de erros durante a interação automatizada. Caso o usuário seja incapaz de retomar o controle do sistema, tais erros podem resultar em acidentes. No entanto, Gonçalves e Quaresma (2015) também afirmam que "não necessariamente falhas representam erros, nem mesmo erros necessariamente causam acidentes", sendo possível que tais problemas sejam resolvidos ou mitigados, uma vez que o usuário retoma o controle e corrige a situação, diminuindo assim a ocorrência de acidentes.

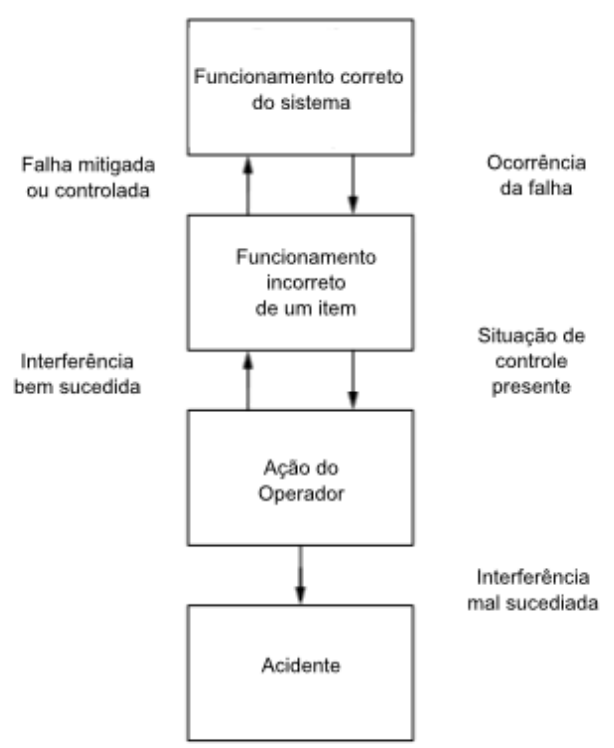

Figura 3.3 - Esquema de como riscos geram acidentes (ISO 26262). 
Harrys e Beringer (2007) apud Gikkas (2013) e HSE (2003) citam as possíveis causas de erros ou falhas em um sistema automatizado:

- Falta de treino dos operadores para utilizar o sistema;

- A falta de um modelo conceitual que auxilie o entendimento das operações realizadas automaticamente;

- Mau funcionamento devido a limitações dos sensores;

- Sistemas não instalados de acordo com as regras de segurança;

- Interpretações imprecisas que podem oferecer um suporte não satisfatório para o usuário.

Pesquisadores como Young (2013), Parasuraman e Rilley (2009) afirmam que problemas de interação Humano-Automatização envolvem três fatores humanos fundamentais para o controle do sistema e que aumentam o risco de acidentes caso não estejam equilibrados, sendo eles a confiança, a carga de trabalho e a consciência na situação. Estes fatores são interligados, e em geral a queda de um deles acarreta em prejuízos para os outros também.

\section{Confiança}

Para Parasuraman (2009), problemas de HAI em relação a confiança em geral acontecem quando uma previsão errada em relação ao sistema é feita. Young (2013) e Decker (2004) afirmam que os problemas podem ser resultados tanto de excesso quanto de falta de confiança no sistema. Esses problemas são divididos ou compostos em a) autoconfiança; b) confiança no sistema; c) confiabilidade do sistema. Esta confiança determina o nível necessário de monitoramento do sistema automatizado por parte do operador - ora excessiva, comprometendo as outras tarefas, ora escassa, fazendo com que o usuário esteja despreparado para reagir. Young (2013) afirma que os principais problemas de confiança em máquinas envolvem a confiança do operador em relação a alarmes falsos e mudanças de comportamento.

\section{Consciência da situação}

Endsley (1998), afirma que consciência da situação é "a percepção dos elementos do ambiente dentro de um volume de tempo e espaço, a compreensão de seu significado, e a projeção de seu estado futuro". Uma característica fundamental 
da consciência da situação é que seu conceito se traduz em diagnóstico de diferentes estados em que o operador humano se situe durante a interação com sistemas autônomos. Portanto, possui um caráter prescritivo quanto a diferentes soluções possíveis para um problema. Dekker (2004) e Kowalsky (2013) afirmam que um dos principais problemas na automatização é um erro de modo (quando uma máquina muda de estado sem dar feedback para o usuário), fazendo com que ele tenha expectativas errôneas sobre as futuras ações do sistema em situação crítica que precise interpretar seu funcionamento, aumentando o risco de acidentes. Grande parte dos erros humanos envolvendo automatização é causada pela falta de feedback em relação ao status do sistema.

\section{Carga de trabalho}

Existem muitos paralelos entre consciência situacional e carga de trabalho mental. Ambos são parâmetros que distinguem comportamento e performance, da mesma forma que possibilitam uma triangulação entre psicologia, performance, e avalições subjetivas combinadas à análises de tarefas e modelos computacionais (Wickens, 2000). Semelhante a consciência situacional, a carga de trabalho, gera diagnósticos específicos com soluções de ergonomia quando o trabalho é abaixo do esperado. De uma forma mais geral, carga de trabalho pode ser descrita como a relação entre a função dos recursos mentais exigidos por uma tarefa e os recursos disponíveis para o operador humano.

O nível de redução na carga de trabalho depende muito da confiabilidade no sistema operado (Dixon \& Wickens, 2004). De acordo com Dixon e Wickens (2004), os níveis de confiabilidade em cerca de $60 \%$ a $70 \%$ podem deixar de proporcionar benefícios ao desempenho. Outro fator importante na carga de trabalho no trabalho com robôs é o conceito de aquisição de contexto. Quando o operador alterna entre tarefas, o esforço mental atribuído a cada tarefa equivale a um aumento da demanda nos recursos cognitivos do operador, ou seja, tempo gasto no processamento mental necessário para fazer a mudança e lidar com cada uma das tarefas desejadas aumenta a carga e trabalho. A carga de trabalho de um operador de robô também pode ser afetada pelos diversos fatores no ambientes de controle robótico. 


\subsection{4.}

\section{Tipos de erros com automação}

Gonçalves e Quaresma (2015) realizaram uma extensa revisão bibliográfica dos principais autores na área de interação Humano-Automatização para consolidar os tipos de erro com automação a partir de um diagrama de afinidades. Essa classificação foi modelada a partir do esquema apresentado no OODA LOOP para viabilizar uma análise das características dos tipos de erro dentro do contexto de interação com sistemas autônomos. No modelo OODA, o operador 1) deve estar atento e ser capaz de observar com clareza todos os pontos referentes ao funcionamento do sistema; 2) ele deve ser capaz de distinguir e interpretar a informação observada de maneira a entender o que está se passando; 3) uma vez consciente da situação, deve ser capaz de tomar a decisão correta de acordo com o cenário; 4) ele deve ser capaz de executar a ação planejada sem grandes dificuldades e em tempo hábil. Neste contexto, apresentam-se os principais tipos de erros encontrados por Gonçalves e Quaresma (2015):

- Erro de modo: Este tipo de erro acontece quando o operador não tem a noção exata do estado atual do sistema automatizado, por isso não consegue agir apropriadamente no em uma situação que necessite interferência direta no funcionamento do sistema. Muito comum em operadores com pouca familiaridade com o sistema operado, este tipo de erro ocorre no processo de orientação do usuário, e interfere diretamente em questões relacionadas à consciência da situação.

- Out of the Loop: Este tipo de erro acontece quando a vigilância do usuário sob determinado aspecto está em níveis baixos ou inexistentes, não notando o funcionamento do sistema, e assim tornando-se incapaz de agir com prontidão, caso necessário, durante uma situação atípica. Este tipo de erro ocorre no processo de observação por parte do usuário, comprometendo diretamente questões ligadas à consciência da situação e carga de trabalho.

- Excesso de confiança: Este tipo de erro acontece quando mesmo ao observar uma irregularidade no funcionamento do sistema, o operador se recusa a aceitar o fato como erro, confiando mais na precisão do sistema 
do que em si próprio. Este tipo de erro é muito comum em operadores com pouca experiência com automatização e ocorre na tomada de decisão do usuário, interferindo em questões relacionadas à consciência da situação e confiança do usuário.

- Falta de confiança: Análogo ao excesso de confiança, este tipo de erro acontece quando mesmo observando nitidamente o funcionamento normal do sistema automatizado, o usuário se recusa a confiar nas ações executadas pela máquina, interferindo desnecessariamente ou fazendo esforço exagerado em sua vigilância. Este tipo de erro ocorre no processo de tomada de decisão do usuário e interfere em questões de carga de trabalho e confiança.

- Vacilo de atenção: Tipo de erro está diretamente ligado a aspectos de falibilidade humana - fadiga, distração e afins. Ocorre quando, mesmo em estado de alerta, o operador se mostra inapto a assimilar todas as variáveis relevantes durante o funcionamento do sistema. Este tipo de erro acontece no processo de observação do usuário e interfere em questões diretamente relacionadas à carga de trabalho.

- Incapacidade operacional: Tipo de erro que ocorre quando, apesar da leitura certa do cenário e tomada de decisão precisa, o operador se mostra incapaz de executar as ações planejadas em tempo hábil, seja pela complexidade da tarefa ou pelo pequeno espaço de tempo. Este tipo de erro acontece no processo de ação do usuário, interferindo em questões relacionadas exclusivamente à carga de trabalho.

- Imprevisibilidade: Este tipo de erro que acontece quando o operador se mostra incapaz de definir o modelo de funcionamento da máquina, fazendo com que o mesmo não consiga antever as reações do sistema diante de determinada situação eminente. Este tipo de erro ocorre no processo de orientação em conjunto com a tomada de decisão - recorrente em operadores com pouca experiência com o sistema operado. Interfere diretamente em questões relacionadas à consciência da situação.

- Erro de máquina: Este tipo de erro que ocorre quando, apesar de uma interação perfeita entre humano e o sistema automatizado, ocorre um mal funcionamento da máquina, gerando resultados indesejados $\mathrm{e}$ 
imprevisíveis. Este tipo de erro acontece no decorrer do processo de execução da ação por parte da máquina, e não interfere diretamente em nenhuma questão relacionada ao usuário, uma vez que este tipo de falha não pode ser evitado pelo mesmo durante a operação.

- Desconsideração intencional do sistema: Erro mais relacionado à prudência do usuário do que à interação em si, ocorre quando o operador intencionalmente desliga algum sistema relacionado à segurança e age de forma autônoma durante a execução de uma tarefa. Tal erro não é relacionado a nenhum dos processos comumente envolvidos na interação Humano-Automatização. Justamente por desconsiderá-la, interfere diretamente em questões relacionadas à confiança.

Esta caracterização e modelagem de tipos de erro com automação foi de grande importância no referencial teórico desta pesquisa, já que esta tem por objetivo pesquisar falhas comuns de interação e aprofundar o conhecimento sobre a interação bem sucedida com máquinas. Desta forma, apresentar esta modelagem teve dois objetivos: o primeiro de aumentar familiaridade da pesquisadora com a teoria relativa a falhas com automação; e o segundo, foi o de servir como embasamento na análise das entrevistas contextuais, onde usuários revelaram suas maiores dificuldades com sistemas robóticos e consequentemente falhas operacionais. Ao comparar a teoria com a experiência prática dos entrevistados, foi possível cruar as informações relacionando as falhas descritas com os cenários de uso propostos no teste de usabilidade.

\subsection{Modelo de Interação Humano-Robô}

$\mathrm{Na}$ atualidade, robôs são capazes de realizar inúmeras tarefas com níveis distintos de autonomia, por isso o modelo de Interação Humano-Robô (HRI, Human Robot Interaction) pode ser inserido em diferentes contextos de utilização. De acordo com o modelo, o humano interage com o mundo por meio do robô, e a informação necessária para interação é veiculada através de algum tipo de interface ou controle remoto (Goodrich e Olsen, 2003). O humano passa os comandos ao robô, que interpreta essa informação e age de acordo com sua autonomia, implementando alguma ação no mundo externo. Como retorno, as informações 
transmitidas pelo robô para o ser humano não ocorrem de forma direta, elas são obtidas por meio de sensores que precisam de interpretação para moldar o comportamento do robô. Neste contexto, dois loops se estabelecem, (1) o humano interage com o robô através de uma interface; e (2) o robô interage com o mundo através de sensores.

Robôs ainda possuem muitas limitações em relação ao que podem fazer, onde podem atuar e como interpretam informações capturadas. Analogamente, suas GUIs, também podem apresentar limitações. Essas limitações, ocorrem tanto pela tecnologia disponível, que restringe a ação humana e pode resultar em condições de erro em potencial, quanto pela a complexidade e conhecimento necessário para operar o sistema. Como exemplo, a visualização de dados é restrita pelo output dos sensores, um sonar captura imagens que podem ser consideradas de difíceis de interpretar ou incompatíveis com o modelo mental do usuário.

Scholtz (2002) propõe três níveis de interação possíveis entre humanos e robôs. No primeiro nível, temos as interações de supervisão entre um humano e um robô em um local remoto. Neste nível, o supervisor precisa conhecer a missão, ter uma visão geral da situação, assim como compreender as capacidades do robô e quaisquer problemas de funcionamento. Scholtz (2002) aponta que esse nível de interação é semelhante ao domínio de HCI de monitoramento complexo de dispositivos. O segundo nível de interação é de igual para igual, onde cada humano e cada robô contribuem para uma tarefa de acordo com suas capacidades. Nessa situação, o usuário humano precisa conhecer o status e capacidades de ação robô, o modelo de mundo do robô e outras interações que estejam ocorrendo. O terceiro nível de interação é mecânico, onde o usuário é um teleoperador, exigindo que seja também um especialista no robô. Neste nível, o usuário deve ter informações sobre os sensores do robô, e outros trabalhos que precisam atenção, bem como efeitos de ajustes, limites de tempo e uma visão geral da missão robótica.

\section{Princípios da interação com robôs}

Goodrich e Olsen (2003) abordaram o comportamento humano na interação com robôs e desenvolveram um conjunto de princípios baseados nas limitações tecnológicas do modelo HRI. Os princípios têm com objetivo minimizar problemas ligados aos fatores humanos observados na interação remota com robôs: carga e trabalho, atenção e confiança. A ideia é propor práticas que abordem aspectos gerais 
da interação remota por meio de GUI que possam ser aplicados em contextos de uso diferentes. As bases para esses princípios são métricas relacionadas ao desempenho de sistemas, sendo elas; tempo de negação (por quanto tempo um robô pode desempenhar uma tarefa de forma eficaz sem interação humana), o tempo de interação (o tempo em que o desempenho de um robô aumenta do limiar até o máximo após a interação humana começar), demanda de atenção do robô (é necessário muito tempo para operar um robô em função da relação matemática entre tempo de negação e tempo de interação), tempo livre (a quantidade de tempo restante para tarefas secundárias durante a IHR - também uma função dos tempos de negação e interação) e ventilação (o número de IHR que pode ser executado simultaneamente, dado que os robôs são os mesmos) (Chen, Haas, Pillalamorri e Jacobson, 2006). Os princípios de Goodrich e Olsen (2003) representam boas práticas na interação com sistemas robóticos. Ao se basear nas métricas de desempenho de sistemas citadas acima, criou-se uma forma de medir a performance do usuário e também outros aspectos importantes na usabilidade de RUIs.

\section{3. \\ O papel do ser humano na interação com robôs}

O papel do humano na interação com robôs foi definido e descrito de muitas maneiras em virtude de suas possibilidades de interação. Grande parte da pesquisa de HRI é baseada em estudos onde operadores e robôs desempenham papéis específicos como por exemplo, humano como teleoperador ou como espectador. Scholtz e Bahrami (2003) definem três funções (supervisor, operador e par) que ainda podem ser subdivididas em papéis mais específicos. Os supervisores são responsáveis pela supervisão e intervenção quando necessário. O papel do operador é dividido entre operador e mecânico. O operador manipula, configura e programa o robô enquanto o mecânico resolve as falhas técnicas e de hardware. O par é ainda subdividido no companheiro de equipe e no espectador. Os colegas de equipe trabalham em equipes de androides, enquanto os espectadores não estão diretamente associados ao robô e, portanto, não requerem treinamento formal. Os espectadores geralmente se envolvem em alguma interação social com ativos robóticos, direta ou indiretamente. Outros definiram os papéis dos humanos e dos 
robôs em termos de operadores e solucionadores de problemas (Murphy, 2004), onde os operadores controlam a manipulação do robô e os solucionadores de problemas são aqueles que dirigem as missões robóticas em geral e analisam os dados recebidos pelo robô. 


\section{4 \\ Usabilidade e design no desenvolvimento de RUls}

Robot User Interfaces (RUI) são GUI específicas para a interação com robôs remotos, que permitem a realização de tarefas complexas. O que as difere de outras GUI não é como seus elementos são desenhados, e sim o comportamento humano resultante da interação com robôs remotos. Para encontrar as diretrizes que atendam a tais especificidades de interação, é preciso começar no comportamento humano. O papel central de humanos em sistemas que possuem automatização é o de assumir o controle de supervisão (Parasuraman, 2006). No papel de supervisor de uma operação remota, o operador monitora o funcionamento da máquina e por isso necessita de comunicação eficiente para comandar o sistema e acompanhar seu funcionamento. Tais dificuldades características do ambiente remoto podem muitas vezes acarretar em falhas operacionais, e é a partir da relação destas falhas com fatores humanos que as diretrizes de design serão abordadas nesta pesquisa.

No design, seguir regras não é tão simples quanto seguir receita de bolo. Para estabelecer um padrão de como nos orientamos de acordo com os 'princípios' de design, é preciso fazer algumas considerações. Princípios têm um caráter geral, com papel fundamental no desenvolvimento de uma teoria da qual outras leis podem surgir. Portanto, a literatura sobre princípios de design mostra semelhanças nos apontamentos de seus autores sobre aspectos gerais do trabalho de designer. Já diretrizes são normas de procedimento, como uma linha que determina o traçado de uma estrada. No caso do design, muitas vezes, estas diretrizes descrevem objetivos ao invés de ações. Estes objetivos, por sua vez, são definidos de forma quase genérica para que possam ser aplicados amplamente em diversas situações. Como resultado, temos a aplicabilidade destas regras variando de acordo com sua interpretação.

No contexto da robótica, este problema pode ser entendido sob a perspectiva de que muitas vezes as características desejadas para robôs podem ter objetivos conflitantes; ser leve e resistente, ou ser multifuncional e fácil de aprender. Para desenhar interações entre humano e a máquina bem-sucedidas, é preciso conhecer 
a fundo não apenas limitações e características, mas também o ambiente em que o robô vai operar. O conhecimento sobre os domínios de cada agente da operação ajuda a delinear o que caracteriza as diretrizes que podem ser aplicadas à cada situação.

\section{1.}

\section{Princípios de Design na Interação com robôs}

Ao comparar princípios de design dos autores Nielsen (1994), Schneiderman (1998) e Jordan (1998) é possível encontrar similaridades em seus apontamentos. A razão para essa semelhança é que, em sua maioria, estes princípios se baseiam na psicologia humana: como as pessoas percebem, aprendem, raciocinam, lembram e convertem intenções em ações. Os quadros a seguir (Quadro 4.1 até 4.7) buscam estabelecer uma relação dos princípios da HRI para interação eficiente com robôs de Goodrich e Olsen (2003), mencionados no capítulo 3, com os princípios de design descritos por Nielsen (1994), Schneiderman (1998) e Jordan (1998). Seu objetivo é enquadrar cada princípio do modelo da interação com robôs com os aspectos de caráter geral do design de interfaces que são aplicados em maior profundidade para estabelecer uma melhoria acentuada no design de interfaces, com referência aos problemas de usabilidade anteriormente observados.

\section{Mudança de Modo Implícita}

Este princípio estipula que sempre que o modo de controle do robô precise ser modificado, esta troca leve o mínimo de tempo e esforço possível. Ademais, a troca não deve requerer do usuário um modelo mental diferente do aplicado anteriormente.

Quadro 4.1 - Relação do princípio da HRI (Goodrich and Olsen, 2003) 'mudança de modo implícita' com princípios de design de Jordan (1998), Schneiderman (1998) e Nielsen (1994). 


\begin{tabular}{|c|c|c|c|}
\hline $\begin{array}{c}\text { Princípios HRI } \\
\text { (Goodrich \& Olsen) }\end{array}$ & Princípios Jordan (1998) & Scheneiderman (1998) & Nielsen (1994) \\
\hline $\begin{array}{l}\text { 1. Mudança de Modo } \\
\text { Implícita: }\end{array}$ & $\begin{array}{l}\text { 1. Consistência. Permite } \\
\text { que usuários generalizem } \\
\text { os requisitos de tarefas em } \\
\text { diferentes produtos ou } \\
\text { tarefas diferentes ("As } \\
\text { inconsistências podem } \\
\text { levar a erros"). }\end{array}$ & $\begin{array}{l}\text { 1. Esforce-se para a } \\
\text { consistência. Devem ser } \\
\text { necessárias sequências } \\
\text { consistentes de ações em } \\
\text { situações semelhantes; } \\
\text { uma terminologia idêntica } \\
\text { deve ser usada em guias, } \\
\text { menus e telas de ajuda; } \\
\text { assim como comandos } \\
\text { consistentes devem ser } \\
\text { empregados por toda } \\
\text { parte. }\end{array}$ & $\begin{array}{l}\text { 4. Consistência e padrões. } \\
\text { Os usuários não devem ter } \\
\text { que se perguntar se } \\
\text { diferentes palavras, } \\
\text { situações ou ações } \\
\text { significam a mesma coisa. } \\
\text { Siga as convenções da } \\
\text { plataforma." }\end{array}$ \\
\hline
\end{tabular}

Sob a perspectiva de desempenho de um sistema, o controle deve ser o mais fluido o possível. Considerando a abrangência de modelos mentais passíveis para um usuário enquanto supervisor ou operador, a mudança de autonomia ou visualização do controle deve ficar clara para o usuário. Desta forma, se relaciona com os princípios de design no que refere à consistência. Todas as listas de princípios e heurísticas estabelecidas por Nielsen (1994), Schneiderman (1998) e Jordan (1998) falam do mesmo aspecto. Sabendo que inconsistências podem induzir a erros (Jordan, 1998) devem se fazer necessárias sequências consistentes de ações em situações semelhantes (Schneiderman, 1998). Usuários não devem ter que se perguntar se diferentes palavras, situações ou ações significam a mesma coisa.

\section{Uso de Pistas Naturais}

Este princípio fala da importância de fornecer pistas naturais à usuários. Essas pistas devem ser oriundas da base pré-existente de dados e expressões humanas que transmitem intenção. Referências familiares, como por exemplo a visualização de mapas cartográficos, que é uma forma 'comum' de exibir esse tipo de informação, e por isso, pode ser a mais indicada na projeção de informação em uma RUI. 
Quadro 4.2 - Relação do princípio da IHR (Goodrich and Olsen, 2003) 'uso de pistas naturais' com princípios de design de Jordan (1998), Schneiderman (1998) e Nielsen (1994).com princípios de design.

\begin{tabular}{|c|c|c|c|}
\hline $\begin{array}{c}\text { Princípios HRI } \\
\text { (Goodrich \& Olsen) }\end{array}$ & Princípios Jordan (1998) & Scheneiderman (1998) & Nielsen (1994) \\
\hline $\begin{array}{l}\text { 2. Uso de pistas } \\
\text { naturais }\end{array}$ & $\begin{array}{l}\text { 7. Claridade Visual } \\
\text { Considera a escala, } \\
\text { localização e a distância } \\
\text { (ou seja, os botões são } \\
\text { rotulados, ifacilmente } \\
\text { acessíveis, suas nterfaces } \\
\text { possuem distâncias } \\
\text { proximais e são } \\
\text { posicionados de maneiras } \\
\text { convenientes). }\end{array}$ & $\begin{array}{l}\text { 2. Permita que usuários } \\
\text { usem atalhos. À medida } \\
\text { que a frequência de uso } \\
\text { aumenta, os desejos do } \\
\text { usuário diminuem o } \\
\text { número de interações e } \\
\text { aumentam seu ritmo. As } \\
\text { abreviações, teclas de } \\
\text { função, comandos ocultos } \\
\text { e instalações de macro } \\
\text { são muito úteis para um } \\
\text { usuário experiente. }\end{array}$ & $\begin{array}{l}\text { 7. Flexibilidade e eficiência } \\
\text { de utilização Aceleradores } \\
\text { (invisivel para usuários } \\
\text { novatos) pode por vees } \\
\text { acelerar a interação para o } \\
\text { usuário especializado, de } \\
\text { tal forma que o sistema } \\
\text { pode servir tanto para } \\
\text { usuários inexperientes e } \\
\text { experientes. Permita que } \\
\text { os usuários adaptem ações } \\
\text { frequentes. }\end{array}$ \\
\hline
\end{tabular}

Princípios de design que abordam aspectos da interação relacionados à clareza visual, como a escala e localização de elementos projetados de maneira conveniente e facilmente acessada (Jordan, 1998). Scheneiderman (1998) aborda o uso de atalhos, permitindo que usuários necessitem de menos interações para que um sistema sirva tanto aos usuários mais experientes quanto aos menos experientes. Já as heurísticas de Nielsen (1994) falam de flexibilidade e eficiência de interação, através do uso de aceleradores, que também podem ser considerados atalhos, permitindo que usuários adaptem ações frequentes. Em geral, atalhos são mais comumente usados por usuários experientes, que com tempo de uso criam técnicas e hábitos relacionados a experiência com determinado sistema. No entanto, atalhos também são de grande validade a usuários novos, principalmente no caso de RUIs quando precisam de treinamento e estes recursos podem salvar tempo e consequentemente evitar sobrecarga mental. A visualização de mapas e cartografia pode ser considerada um exemplo de uma pista natural (Figura 4.1). 


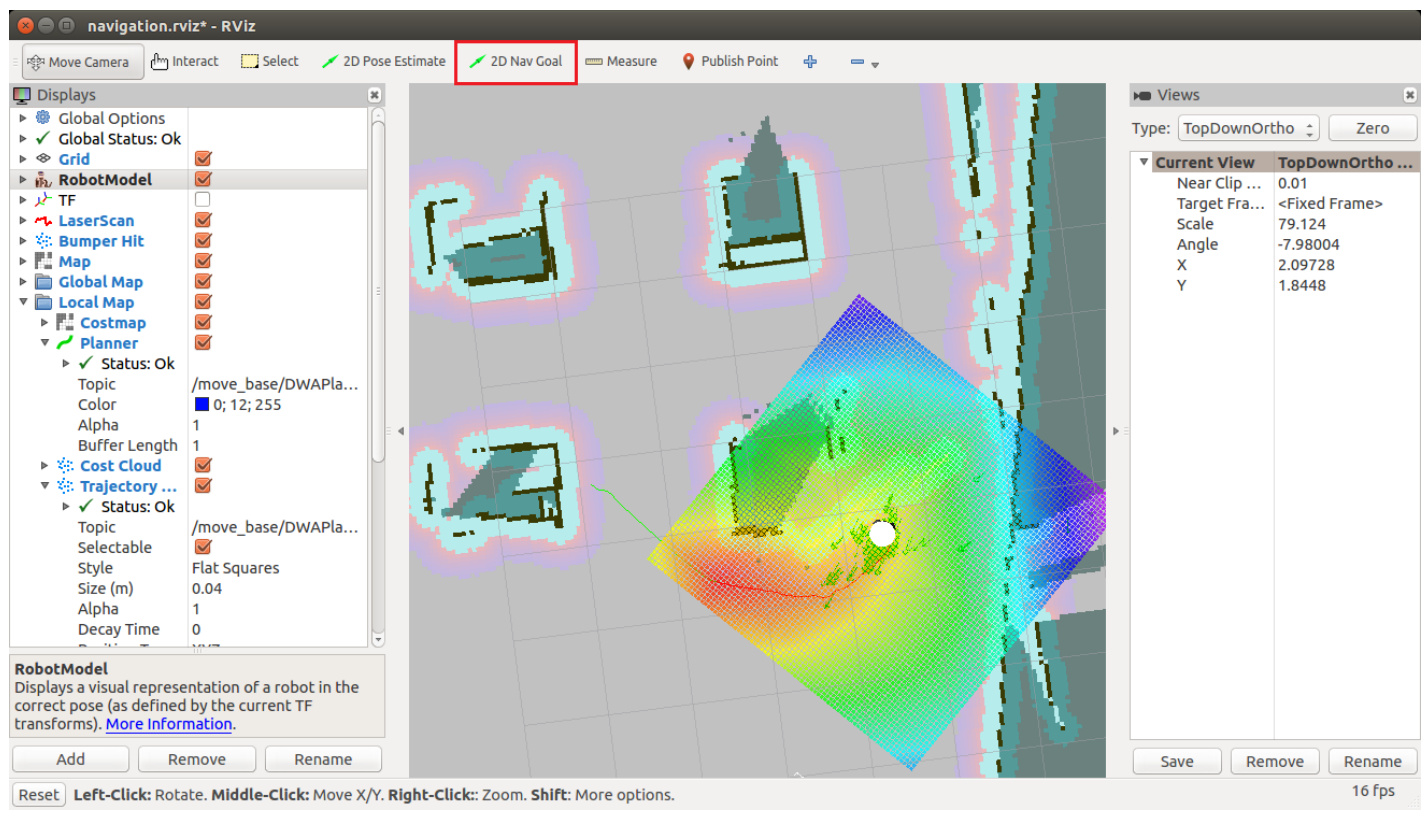

Figura 4.1 - RUI de robô móvel que oferece visualização de um mapa do ambiente de contato direto na interface. Fonte: (https://hackaday.io/project/8588-diy-autonomousmobile-robot).

\section{Manipular o mundo de forma direta}

Este princípio fala da importância do contato direto do operador com o ambiente operacional representado na interface. A quantidade de interação com o robô deve ser minimizada facilitando seu controle e/ou monitoramento. A ligação direta entre o operador e o ambiente operacional reduz a carga de trabalho, já que o operador precisa apenas do modelo mental do ambiente e não do robô, para iniciar com êxito comandos de ação. Um exemplo de um link direto seria uma tela de toque que exibe imagem representando o ambiente. $\mathrm{O}$ operador tocando a tela para indicar um novo destino para o robô é um exemplo de comando essencial para entrada direta de movimentos do robô na operação.

Quadro 4.3 - Relação do princípio da IHR (Goodrich and Olsen, 2003) 'manipular o mundo de forma direta' com princípios de design de Jordan (1998), Schneiderman (1998) e Nielsen (1994).com princípios de design. 


\begin{tabular}{|c|c|c|c|}
\hline $\begin{array}{c}\text { Princípios HRI } \\
\text { (Goodrich \& Olsen) }\end{array}$ & Princípios Jordan (1998) & Scheneiderman (1998) & Nielsen (1994) \\
\hline $\begin{array}{l}\text { 3. Manipular o mundo } \\
\text { de forma direta }\end{array}$ & $\begin{array}{l}\text { 2. Compatibilidade. } \\
\text { É o potencial do design } \\
\text { para significar } \\
\text { compreensão, expectativa } \\
\text { e habilidade do usuário. }\end{array}$ & & $\begin{array}{l}\text { 2. Correspondência entre o } \\
\text { sistema e o mundo real. } \\
\text { O sistema deve falar o } \\
\text { idioma dos usuários, com } \\
\text { palavras, frases e conceitos } \\
\text { familiares para o usuário, } \\
\text { em vez de termos } \\
\text { orientados ao sistema. } \\
\text { Siga as convençôes do } \\
\text { mundo real, fazendo com } \\
\text { que as informações } \\
\text { apareçam em uma ordem } \\
\text { natural e lógica. }\end{array}$ \\
\hline
\end{tabular}

Manipular o mundo de forma direta se relaciona o entendimento do usuário pela forma como o sistema expressa o mundo dos robôs. Por isso, princípio ligado a compatibilidade de Jordan (1998) nos remete a elementos que são amplamente utilizados em outros dispositivos e com isso sua familiaridade auxilia na performance do sistema. Nielsen (1994) nos fala da necessidade de compatibilidade entre o sistema e o mundo real, sinalizando sobre como convenções do mundo real fazem com que informações pareçam em ordem natural e lógica. Um exemplo de um link direto seria uma tela de toque que exibe imagem representando o ambiente. Nela, o operador pode tocar e indicar um novo destino para o robô, sendo o comando essencial para entrada direta de movimentos do robô na operação (Figura 4.2).

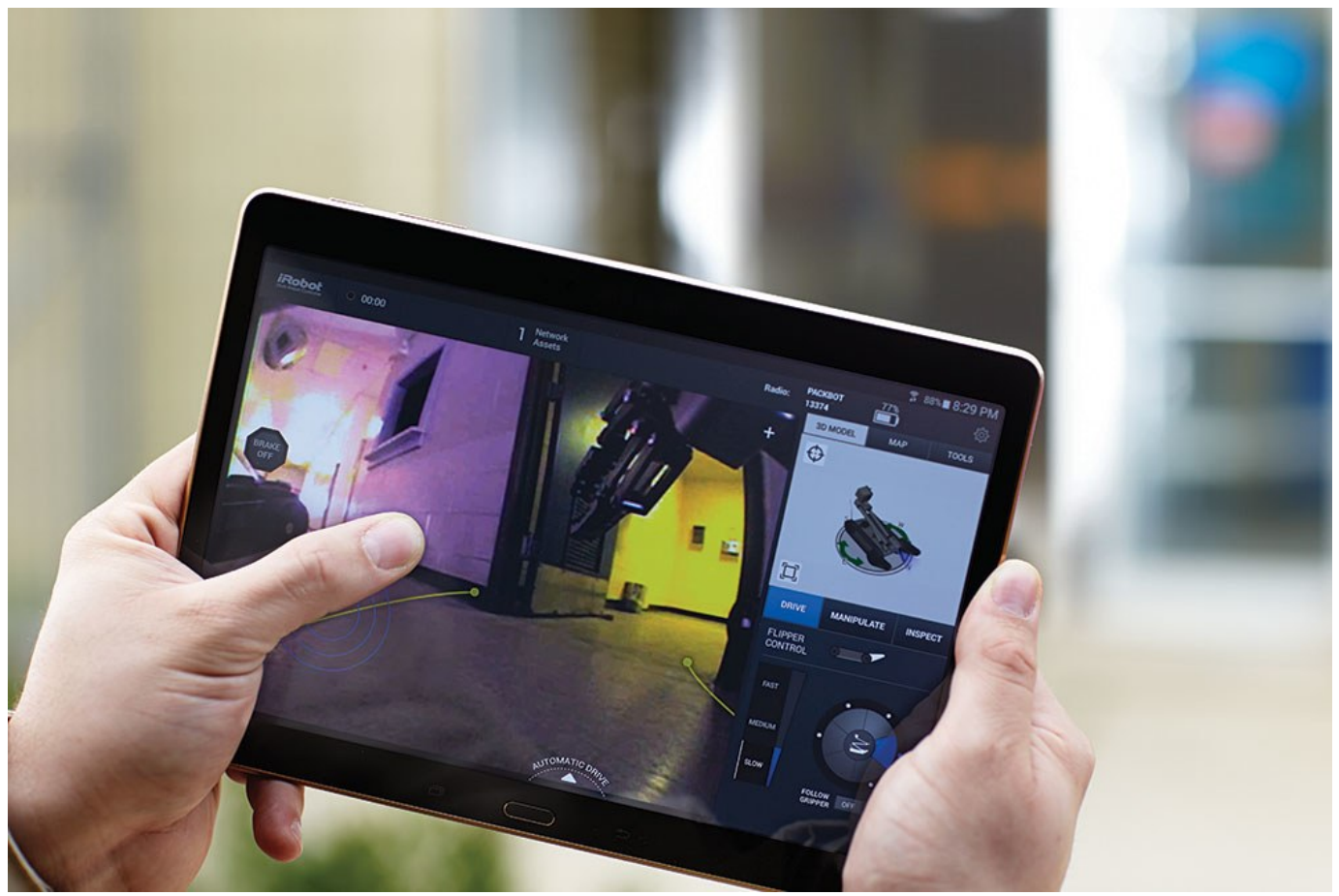


Figura 4.2 - Usuário indica direção na tela onde robô deve se dirigir. (Fonte: https://www.wired.com/2014/10/irobot-android-app/)

\section{Manipulação da relação entre o mundo e o robô}

Este princípio foi elaborado porque nem sempre é possível fazer a ligação direta entre operador e ambiente de destino na RUI. Assim, quando as ligações diretas não são possíveis, o melhor a se fazer é projetar a interface para que a concentração do operador permaneça no ambiente de destino. Se uma tarefa precisa de muitas ações para ser concretizada, sua projeção deve acontecer de forma sequencial e a informação disponibilizada deve ser concisa a fim de facilitar o desempenho do usuário e não sobrecarregar sua carga mental.

Quadro 4.4 - Relação do princípio da IHR (Goodrich and Olsen, 2003) 'manipular a relação entre o e o robô' com princípios de design de Jordan (1998), Schneiderman (1998) e Nielsen (1994).com princípios de design.

\begin{tabular}{|c|c|c|c|}
\hline $\begin{array}{c}\text { Princípios HRI } \\
\text { (Goodrich \& Olsen) }\end{array}$ & Princípios Jordan (1998) & Scheneiderman (1998) & Nielsen (1994) \\
\hline $\begin{array}{l}\text { 4. Manipulação da } \\
\text { relação entre o } \\
\text { mundo e o robô }\end{array}$ & $\begin{array}{l}\text { 6. Controle por parte do } \\
\text { usuário. Projetar um } \\
\text { produto de maneira a } \\
\text { maximizar o controle do } \\
\text { usuário sobre suas próprias } \\
\text { ações, sobre o produto, e } \\
\text { sobre o estado no qual se } \\
\text { encontra o produto. } \\
\text { 3. Considerações de } \\
\text { recursos do usuário. Guias } \\
\text { de design com relação à } \\
\text { linguagem corporal de } \\
\text { mãos, olhos, ouvidos, etc, } \\
\text { usando som, pistas visuais } \\
\text { e funções tácteis. }\end{array}$ & & $\begin{array}{l}\text { 2. Correspondência entre o } \\
\text { sistema e o mundo real. } \\
\text { O sistema deve falar o } \\
\text { idioma dos usuários, com } \\
\text { palavras, frases e conceitos } \\
\text { familiares para o usuário, } \\
\text { em vez de termos } \\
\text { orientados ao sistema. } \\
\text { Siga as convenções do } \\
\text { mundo real, fazendo com } \\
\text { que as informações } \\
\text { apareçam em uma ordem } \\
\text { natural e lógica. }\end{array}$ \\
\hline
\end{tabular}

Este princípio associa o desempenho do sistema com seu controle. Para manipular o robô, precisamos de controle preciso, para controles precisos, precisamos de mecanismos que sejam intuitivos e facilitem essa manipulação. No caso dos princípios de design, 'controle por parte de usuário' de Jordan (1998) e o 'controle e liberdade' por parte de Nielsen (1994) falam exatamente da importância de uma projeção primordial destes controles nas interfaces. Jordan (1998) também aborda a questão relacionada a recursos do operador que permitem abrangência na forma de exercer esse controle. Schneiderman (1998) e Nielsen (1994) também mencionam o suporte de 'desfazer ações' como ferramenta essencial na manipulação do sistema. Por exemplo, um ROV (Remotely Operated Vehicle), é 
um veículo subaquático que permite a observação remota do fundo do mar e estruturas submarinas. Em ambientes restritos por pedras ou cavidades a precisão na locomoção do robô é essencial para a captura da informação correta.

\section{Facilitar a manipulação de Informação}

Este princípio requer que informações dadas ao operador estejam abertas à manipulação conforme necessário. Por exemplo, o feedback específico sobre o estado de um robô deve permitir manipulação e consequentemente sua realimentação.

Quadro 4.5 - Relação do princípio da IHR (Goodrich and Olsen, 2003) 'facilitar a manipulação de informação' com princípios de design de Jordan (1998), Schneiderman (1998) e Nielsen (1994).com princípios de design.

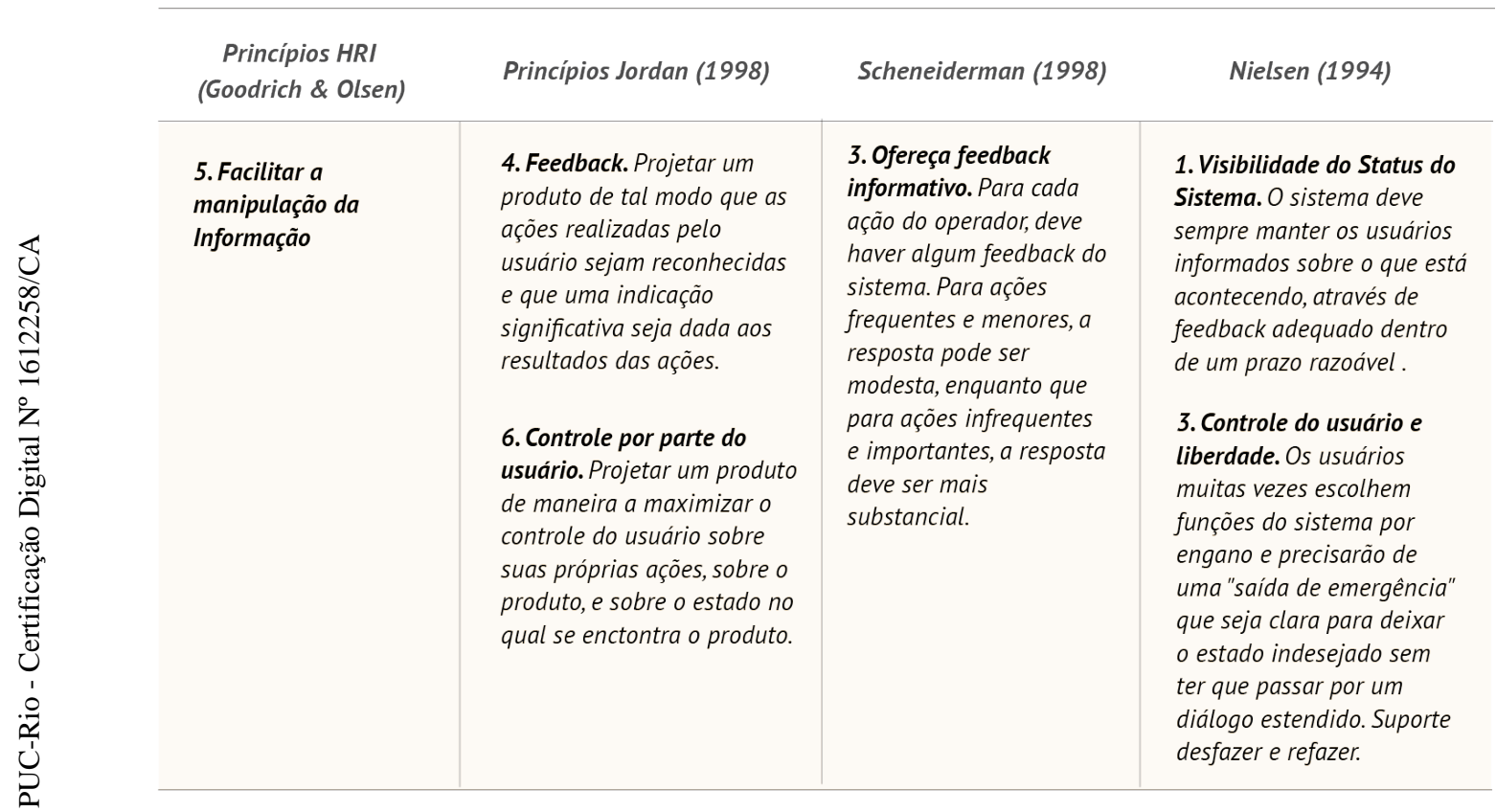

A ideia de manipular informação está ligada tantos aos princípios que nos falam de controle do sistema, quanto ao feedback que muitas vezes valida ações. Assim, os princípios que se relacionam com estas funções são importantes na flexibilidade em que um sistema permitirá liberdade em sua utilização. Jordan (1998) fala em projetar um produto para maximizar o controle do usuário sobre suas ações enquanto Nielsen (1994) menciona a importância da possibilidade de reverter ações. De forma pratica essa facilidade em manipular informação pode ser vista como flexibilidade em visualizar parâmetros de um sistema. Por exemplo, o usuário pode aumentar um o tamanho de determinado gráfico ou estabelecer uma organização de dispositivos da interface da forma que lhe convir. 


\section{Externalizar memória}

Todos os autores abordam um principio relativo a feedback e status do sistema; Nielsen (1994) aborda a questão sob a perspectiva de alerta, sendo o sistema responsável por manter usuários informados dentro de um prazo razoável. Jordan (1998) aborda a importância de uma interface que permita que ações realizadas sejam reconhecidas, enquanto Schneiderman (1998) nos fala de feedback, mas também da priorização de informação de acordo com sua frequência.

Existem dois tipo de memória: a de longo prazo e a de curto prazo. Quanto maior a capacidade de um operador em reter informação na memória (curto prazo), maior seu potencial para armazenar informações necessárias na tomada de decisão. $\mathrm{Na}$ interação com robôs tarefas podem ter etapas ou exigir ações diferentes em momentos diferentes. Desta forma, uma RUI pode auxiliar na externalização de memória, ao disponibilizar informações de acordo com uma hierarquia pertinente às fases da operação

Quadro 4.6 - Relação do princípio de HRI (Goodrich and Olsen, 2003) 'externalizar memória' com princípios de design de design de Jordan (1998), Schneiderman (1998) e Nielsen (1994).

\begin{tabular}{|c|c|c|c|}
\hline $\begin{array}{c}\text { Princípios HRI } \\
\text { (Goodrich \& Olsen) }\end{array}$ & Princípios Jordan (1998) & Scheneiderman (1998) & Nielsen (1994) \\
\hline $\begin{array}{l}\text { 6. Externalizar } \\
\text { memória }\end{array}$ & $\begin{array}{l}\text { 4. Feedback. Projetar um } \\
\text { produto de tal modo que } \\
\text { as ações realizadas pelo } \\
\text { usuário sejam reconheci- } \\
\text { das e que uma indicação } \\
\text { significativa seja dada aos } \\
\text { resultados das ações. }\end{array}$ & $\begin{array}{l}\text { 3. Ofereça feedback } \\
\text { informativo. Para cada } \\
\text { ação do operador, deve } \\
\text { haver algum feedback do } \\
\text { sistema. Para ações } \\
\text { frequentes e menores, a } \\
\text { resposta pode ser modesta, } \\
\text { enquanto que para ações } \\
\text { infrequentes e importantes, } \\
\text { a resposta deve ser mais } \\
\text { substancial. }\end{array}$ & $\begin{array}{l}\text { 1. Visibilidade do Status do } \\
\text { Sistema. O sistema deve } \\
\text { sempre manter os usuários } \\
\text { informados sobre o que } \\
\text { está acontecendo, através } \\
\text { de feedback adequado } \\
\text { dentro de um prazo } \\
\text { razoável } \\
\text { 10. Ajuda e documentação. } \\
\text { Mesmo que um sistema } \\
\text { não deve necessitar de } \\
\text { documentação para ser } \\
\text { usado, é necessário que se } \\
\text { forneça ajuda e } \\
\text { documentação. Qualquer } \\
\text { informaçâo desse tipo deve } \\
\text { ser fácil de pesquisar, } \\
\text { focada na tarefa do } \\
\text { usuário, listar etapas } \\
\text { concretas a serem } \\
\text { realizadas e não ser muito } \\
\text { grande. }\end{array}$ \\
\hline
\end{tabular}




\section{Gerenciamento de atenção}

Este princípio busca garantir que o foco do operador permaneça nas ações pertinentes ao estagio em que a operação se encontra. Para além disso, a projeção de elementos na interface permite noção geral da operação e ao mesmo tempo facilita o acesso a questões pontuais de funcionamento. Desta forma, o operador se dirige a informações críticas nos momentos adequados.

Quadro 4.7 - Relação do princípio da HRI (Goodrich and Olsen, 2003) 'gerenciamento de atenção' com princípios de design de design de Jordan (1998), Schneiderman (1998) e Nielsen (1994).

\begin{tabular}{|c|c|c|c|}
\hline $\begin{array}{c}\text { Princípios HRI } \\
\text { (Goodrich \& Olsen) }\end{array}$ & Princípios Jordan (1998) & Scheneiderman (1998) & Nielsen (1994) \\
\hline $\begin{array}{l}\text { 7. Providenciar o } \\
\text { gerenciamento de } \\
\text { atenção }\end{array}$ & $\begin{array}{l}\text { 4. Feedback. Projetar um } \\
\text { produto de tal modo que as } \\
\text { ações realizadas pelo } \\
\text { usuário sejam reconhecidas } \\
\text { e que uma indicação } \\
\text { significativa seja dada aos } \\
\text { resultados das ações. }\end{array}$ & $\begin{array}{l}\text { 3. Ofereça feedback } \\
\text { informativo. Para cada ação } \\
\text { do operador, deve haver } \\
\text { algum feedback do sistema. } \\
\text { Para ações frequentes e } \\
\text { menores, a resposta pode } \\
\text { ser modesta, enquanto que } \\
\text { para ações infrequentes e } \\
\text { importantes, a resposta } \\
\text { deve ser mais substancial. } \\
\text { 4. Projetar diálogos que } \\
\text { indiquem quando a tarefa } \\
\text { terminou. As ações devem } \\
\text { ser organizadas com um } \\
\text { início, um meio e um fim, e } \\
\text { com histórias: bem } \\
\text { redigidas! Um feedback } \\
\text { informativo no fim da } \\
\text { sequência permite o } \\
\text { usuário constatar o fim de } \\
\text { sua tarefa. } \\
\text { 5. Ofereça um simples } \\
\text { tratamento de erros. Tanto } \\
\text { quanto possível, projete o } \\
\text { sistema para que o usuário } \\
\text { não consiga fazer um erro } \\
\text { grave. Se um erro for feito, o } \\
\text { sistema deve ser capaz de } \\
\text { detectar o erro e oferecer } \\
\text { mecanismos simples e } \\
\text { compreensíveis para lidar } \\
\text { com o erro. }\end{array}$ & $\begin{array}{l}\text { 1. Visibilidade do Status } \\
\text { do Sistema. O sistema } \\
\text { deve sempre manter os } \\
\text { usuários informados } \\
\text { sobre o que está } \\
\text { acontecendo, através de } \\
\text { feedback adequado } \\
\text { dentro de um prazo } \\
\text { razoável. } \\
\text { 10. Ajuda e documentação. } \\
\text { Mesmo que um sistema } \\
\text { não deve necessitar de } \\
\text { documentação para ser } \\
\text { usado, é necessário que se } \\
\text { forneça ajuda e } \\
\text { documentação. Qualquer } \\
\text { informação desse tipo deve } \\
\text { ser fácil de pesquisar, } \\
\text { focada na tarefa do } \\
\text { usuário, listar etapas } \\
\text { concretas a serem } \\
\text { realizadas e não ser muito } \\
\text { grande. }\end{array}$ \\
\hline
\end{tabular}

Gerenciar o sustento da atenção de um operador durante a atividade do sistema é uma das principais dificuldades no trabalho de supervisão. Para tanto, é preciso manter o operador alerta e saber priorizar o nível de atenção para cada atividade na tarefa. Assim, um sistema que ofereça feedback e priorize alertas 
auxilia o operador em seu desempenho. Como exemplo prático podemos citar o fornecimento de ajuda quando necessário e o suporte à reversão de ações.

\section{2.}

\section{Diretrizes para UI design na HRI}

A interação com robôs pode acontecer de formas que variam desde o número de agentes envolvidos (número de humanos e número de robôs) até o nível de autonomia dado a cada agente da operação (Scholtz, 2002). Diretrizes são normas de procedimento geral que podem se aplicar a essa enorme gama de situações mencionadas pelo modelo HRI para garantir ou aumentar a usabilidade de sistemas. Para combater falhas na interação com robôs a abordagem ao problema começa no entendimento de fatores humanos no contexto operacional, ao entender como o usuário se comporta, é possível evitar determinadas situação de uso. A avaliação de usabilidade baseadas nestas diretrizes são aplicadas em maior profundidade para estabelecer uma melhoria acentuada no design de interfaces, relativos a problemas de usabilidade identificados. Para selecionar as diretrizes que se aplicam ao contexto de operação remota com um operador e um sistema robótico automatizado, buscou-se na literatura RUIs desenvolvidas em contextos semelhantes. Como descrito previamente, a interação com automação envolve três fatores humanos fundamentais para a controlabilidade do sistema que podem aumentar o risco de acidentes, sendo eles: confiança, consciência situacional e carga de trabalho. Tais fatores estabelecem uma base para relacionar as diretrizes de design que atendem a suas características, no caso as especificidades de interação que o design de um sistema remoto deve ter. Por isso, após a análise de literatura, as diretrizes serão enquadradas dentro destes fatores para que se crie uma estrutura de entendimento.

Como nos princípios de design de interfaces relacionadas à $\mathrm{HCI}$, à literatura referente a HRI também apresenta semelhanças em seus apontamentos. Isso porque estes apontamentos buscam mitigar os fatores similares em situações variadas. De maneira geral, o design de RUI é um tema de interesse para pesquisadores que trabalham com design de experiência e interfaces no desenvolvimento de robôs. $\mathrm{Na}$ literatura autores abordam o contexto onde um usuário controla um robô automatizado de forma remota. Para avaliar RUIs nesse contexto, pesquisadores 
propuseram métodos e métricas com base em heurísticas de projetos de HCI e HRI. Algumas destas diretrizes são mencionadas com mais frequência, assim procurouse explicá-las de acordo com a abordagem a problemas relativos a sistemas remotos.

Melhorar o desempenho do sistema é um princípio que funciona como base uma série de diretrizes de design, tanto no campo da IHC com Norman (2002) e Jordan (1998) por exemplo, quanto na IHR pelos autores Drury, Scholtz e Yanco (2003, 2004) e Scholtz (2002). Este princípio pode ser considerado genérico e por isso se relaciona com inúmeras diretrizes que falam pontualmente de aspectos na interface para tornar o sistema mais efetivo. Schneiderman (1998) e Nielsen (1994) falam de feedback informativo, prevenção de erros, buscar consistência e padrões, e tantos outros aspectos visuais de interfaces que permitem um sistema com bom desempenho. No contexto deste princípio, como forma conter falhas de interação com sistemas remotos, a diretriz referente a 'redução de etapas interativas necessárias para completar uma tarefa' (Parasuraman, Sheridan \& Wickens, 2000) e (Bahadur, 2012) é frequentemente abordada na literatura relativa ao IHR.

De forma geral, operações remotas evocam princípios relativos à visibilidade do status do sistema (Nielsen, 1994). Dentro deste contexto de visibilidade e feedback informativo, muitas diretrizes são propostas na literatura. Drury, Scholtz e Yanco (2003, 2004) e Fong, Thorpe e Baur (2003) propõem diretrizes sobre 'a necessidade da disponibilidade de informações necessárias para tomar a decisão certa', 'o tempo de acesso às ações na interface deve ser o mais breve o possível' e 'a quantidade de distração ou mudança de atenção entre a cena do robô e a interface de controle deve ser a menor possível'. Para Habib e Baudoin (2010), a RUI deve ser projetada adequadamente para auxiliar operadores e diminuir sua carga de trabalho cognitiva. Já Trevelyan, Hamel e Kang (2008) abordam o problema de carga de trabalho ao oferecer ao operador apenas as informações relevantes, eliminando dados redundantes.

Drury, Hestand e Scholtz (2004) realizaram uma análise extensa de diferentes estruturas no desenvolvimento de graphic user interfaces (GUI) para criar uma base para definição de diretrizes para mitigar ocorrências relacionadas a estes fatores de consciência de situacional; 'fornecer um mapa de onde o robô atua' e 'fornecer mais informações espaciais sobre o robô no ambiente para tornar os operadores mais conscientes dos arredores imediatos dos robôs'. No que se refere ao fator de carga cognitiva de trabalho, mencionam as diretrizes; 'fundir 
informações provenientes de sensores para evitar que o usuário confunda os dados mentalmente'; 'minimizar o uso de múltiplas janelas para aumentar eficiência da interface'; e 'permitir suporte ao usuário que gerencia um ou mais robôs em apenas uma janela'. Com intuito de fornecer ajuda na escolha da modalidade do robô, falam de 'proporcionar assistência ao operador para determinar o nível mais adequado de autonomia robótica em qualquer momento'.

Para sintetizar essas diretrizes de acordo com seus fatores humanos originários, foram criados os quadros abaixo (Quadros 4.8, 4.9 e 4.10) para agrupálas de acordo. Os fatores humanos carga de trabalho, consciência de situacional e confiança, estão interligados e por isso se fazem presentes nas mesmas situações. Por exemplo, se a confiança de um usuário no sistema é muito alta, isso pode acarretar em uma maior propensão a distração com o sistema com uma menor consciência de situação. Por outro lado, uma confiança baixa no sistema pode resultar em uma busca constante por informação elevando a carga de trabalho. Assim, a tarefa de agrupar diretrizes está sujeita a interpretação do contexto onde a interação ocorre. Como um exemplo prático desta perspectiva, a diretriz de Drury, Hestand e Scholtz, (2004) que fala sobre "aumentar a informação sobre o ambiente operacional do robô", pode ser considerada uma ação que aumenta a confiança no sistema, e por isso foi agrupada neste fator. No entanto, a aplicação da diretriz pode além de aumentar a confiança do usuário no sistema, resultar noa aumento da consciência de situação, ou mesmo, diminuir a carga de trabalho. Assim entendese que a forma como essas diretrizes foram agrupadas, atendeu aos fins da pesquisa na criação de uma base de investigação e também as especificidades de interação com robôs observadas ao longo do estudo.

Quadro 4.8 - Diretrizes de design de interfaces na HRI relativas ao fator humano de confiança.

Diretrizes relacionadas a Confiança

(1) Fornecer ajuda na escolha da modalidade do robô. Proporcionar assistência ao operador para determinar o nivel mais adequado de autonomia robótica em qualquer momento. (Drury, Hestand e Scholtz, 2004)

(2) Aumentar Informação sobre ambiente do Robô. Forneça mais informaçôes espaciais sobre o robô no ambiente operacional para tornar os operadores mais conscientes dos arredores imediatos dos robôs. (Drury, Hestand e Scholtz, 2004)

(3) O mundo do robô deve ser projetado de forma similar ao entendimento do ser humano, seguindo convençôes do mundo real, fazendo com que a informação apareça de forma natural e lógica na interface com usuário. (Goodrich e Olsen, 2003) 
Quadro 4.9 - Diretrizes de design de interfaces na HRI relativas ao fator humano de consciência situacional.

\section{Diretrizes relacionadas Consciência Situacional}

(1) Forneça um mapa de onde o robô foi. Forneça mais informações espaciais sobre o robô no ambiente para tornar os operadores mais conscientes dos arredores imediatos dos robôs. (Drury, Hestand e Scholtz, 2004) (2) 0 sistema deve sempre manter os usuários informados sobre o que está acontecendo, através de feedback adequado dentro de um prazo razoável.

(3) 0 sistema deve transmitir seu modelo ao usuário para que o usuário tenha uma compreensão completa da consciência situacional do sistema. (Scholtz)

(4) 0 tempo de acesso às ações na interface deve ser o mais breve o possível (Drury, Scholtz e Yanco, 2004)

(5) A quantidade de distração ou mudança de atenção entre a cena do robô e a interface de

(6) $O$ controle deve ser a menor possivel (Fong, T., Thorpe, C., Baur, C 2003)

(7) A projeção de mundo no sistema deve ser visualizada sob um ponto de vista compatível para o entendimento da tarefa, permitindo que o operador possa determinar se a intervenção é necessária ou não

Quadro 4.10 - Diretrizes de design de interfaces na HRI relativas ao fator humano de carga de trabalho.

Diretrizes relacionadas a Carga de Trabalho

(1) Fundir informações provenientes de sensores para evitar que o usuário confunda os dados mentalmente. (Drury, Hestand e Scholtz, 2004)

(2) A interface deve ser projetada para transmitir informações "apenas o suficiente": o suficiente para que 0 humano possa determinar se a intervenção é necessária, e não tanto que cause sobrecarga. (Scholtz, 2002)

(3) Minimizar o uso de múltiplas janelas para aumentar eficiência da interface. Permitir suporte ao usuário que gerencia um ou mais robôs em apenas uma janela. (Drury, Hestand e Scholtz, 2004)

(4) Oferecer ao operador apenas as informaçōes relevantes, eliminando dados redundantes (Trevelyan, Hamel e Kang, 2008)

(5) A interface deve ser projetada adequadamente para auxiliar operadores e diminuir sua carga de trabalho cognitiva (Habib e Baudoin, 2010) 


\section{Delineamento de Pesquisa}

\section{1.}

Tema

Desenvolvimento de interfaces gráficas do usuário no contexto de interação humano-robô.

\section{2. \\ Problema}

A interação entre humanos e robôs não deixa de ser uma interação entre humanos e computadores. Por isso, o estudo sobre a usabilidade de RUI's começa no entendimento de que é preciso assimilar todos os elementos necessários na realização do trabalho com máquinas. O contexto de uso de RUIs pode apresentar uma configuração mais complexa pela quantidade de fatores que precisam ser articulados no funcionamento de robô. No cenário operacional, além do homem e do computador são necessários outros agentes para realizar a tarefa; a presença do robô e um ambiente operacional externo, mudam a percepção do usuário na interação com o sistema. Somado a este cenário, o fato de que robôs possuem graus de autonomia, lhes confere a capacidade de executar tarefas sem a interferência humana.

Este estudo aborda o caso mais simples de interação entre humanos e robôs (Drury, 2003), que ocorre quando um humano trabalha com um robô apenas. Neste contexto, a máquina realiza a tarefa desejada de forma autônoma, porém ainda exige atenção do operador no monitoramento do trabalho. Em cada momento, o usuário deve se adaptar à interação e o papel que lhe cabe. Por isso, a observação de falhas na interação de usuários com robôs embasa a análise de diretrizes de design que podem contribuir para o aumento de usabilidade de RUIs. A abordagem desta pesquisa considera que, ao inserir um novo agente na interação, o robô, o usuário 
passa a alternar momentos de operador com momentos de monitor devendo, assim, assimilar estas variações para interagir com as RUI's em questão. Em suma, a problemática desta pesquisa gira em torno da prevenção de falhas na interação com robôs. Para isso, procuraremos responder perguntas como quais são as falhas mais comuns observados na interação? Como o entendimento destas falhas pode contribuir para elaboração de RUI's mais eficientes? As diretrizes de design de interfaces existentes hoje contemplam as especificidades deste tipo de usabilidade?

\section{3.}

Hipótese

Se interfaces específicas para sistemas robóticos forem concebidas considerando as especificidades dos modelos de interação humano-robô, as falhas operacionais na interação serão reduzidas.

\section{4 . \\ Variáveis}

\section{Variáveis Independentes}

Diretrizes de interfaces para sistemas robóticos aplicadas a interfaces.

Como exemplo de diretrizes podemos citar: (a) fornecer na interface mais elementos informativos sobre o ambiente espacial do robô, na prática um mapa pode reunir todas as informações necessárias para o usuário executar a tarefa; ou (b) usar um ponto de vista compatível para visualizar a operação, ou seja, transmitir a imagem do robô por ângulo que permita sua identificação e observação de forma ideal para o usuário.

\section{Variáveis Dependentes}

As falhas operacionais mais comuns observadas na interação.

\section{5 .}

\section{Objeto}

Interação com interfaces robóticas. 


\section{6 . \\ Objetivos}

5.6.1.

Objetivo Geral

O objetivo geral da pesquisa é o de avaliar diretrizes específicas para o design de RUI's.

\subsection{2.}

\section{Objetivos Específicos}

O objetivo geral se desdobra nos seguintes objetivos específicos:

- Análisar as interações e design para interfaces com robôs manipuladores;

- Elencar os princípios de design existentes na literatura de HCI e pertinentes na HRI;

- Elencar diretrizes de RUI's existentes;

- Fazer uma síntese de diretrizes pertinentes aos robôs manipuladores;

- Descrever o modelo de interação humano-robô e as possíveis falhas que podem ocorrer nesta interação;

- Investigar com usuários de robôs de serviço quais são suas necessidades, limitações e contexto de trabalho/interação;

- Buscar relação entre falhas de interação com diretrizes e RUI's;

- Testar e validar diretrizes de RUI's.

\section{7 .}

\section{Justificativa}

Robôs manipuladores são amplamente utilizados, desde a indústria até uma extensa atuação na robótica de serviços. São cada vez mais comuns e suas interfaces de usuário têm papel importante no auxílio de cumprimento de tarefas. À medida que a tecnologia avança, o objetivo humano na interação com robôs deve ser o de estabelecer uma colaboração entre o sistema e usuário que possua capacidade maior que seus componentes individuais. Além disso, o aumento de aplicações robóticas criou uma demanda para o desenvolvimento de interfaces de usuário que possibilitem interações mais eficientes, buscando sistemas mais intuitivos e com maior usabilidade. 
Interfaces de usuário robóticas (Robot User Interfaces, RUI's) possuem um caráter mais raro em termos de saída de projeto, um nicho de mercado mais específico e composições de equipe muitas vezes estruturadas apenas na engenharia de software e mecatrônica. Logo, é de grande relevância reforçar a literatura vigente no que se refere ao design e desenvolvimento de RUI's, que fortaleça a função do designer enquanto agente no processo de desenvolvimento de tecnologia. A usabilidade de sistemas robóticos deve ser investigada por seu longo lastro de utilização, tanto na pesquisa quanto em serviços. O desenvolvimento tecnológico nos aproxima destes sistemas antes considerados complexos e, agora, cabe em parte a designers tornar sua utilização fácil ao buscar sistemas intuitivos que sejam capazes de atender a protocolos de comunicação e interação com usuários finais. Isso posto, fica claro que esta pesquisa busca reforçar a literatura vigente no que se refere ao desenvolvimento de interfaces de usuários para robôs além de ser referência para pesquisadores da área, assim como auxílio a órgãos governamentais, industriais ou de setores de produção que lidam com robótica.

Assim, a investigação de métodos para interfaces gráficas de sistemas robóticos é fundamental à medida que a robótica de serviço aumenta em diversas áreas como solução de tarefas complexas, e também como precursora de novas tecnologias que estão ao alcance do usuário comum. 


\section{6 \\ Métodos, técnicas e procedimentos}

O método que proporciona a base investigativa desta pesquisa é o hipotéticodedutivo. Segundo Gil, (2008, p. 30)

O cientista, através de uma combinação de observações cuidadosas, alcança um conjunto de postulados que governam os fenômenos pelos quais esta ingressado, daí deduz ele as consequências por meio de experimentação e, dessa maneira, refuta os postulados, substituindo-os quando necessário por outros e assim prossegue.

A pesquisa exploratória tem por objetivo aumentar a familiaridade do pesquisador com o tema, e possibilitar a averiguação das questões que compõem a problemática do estudo. Os métodos de pesquisa utilizados nesta dissertação foram: pesquisa bibliográfica; entrevistas contextuais e testes de usabilidade. A pesquisa bibliográfica foi realizada com intuito de criar embasamento teórico acerca do tema das RUI (Robot User Interfaces). Seu objetivo foi de compreender como os modelos relativos à interação com robôs devem ser assimilados no trabalho remoto. Posteriormente, a análise do conteúdo foi voltada para princípios e diretrizes de design pertinentes à interação com robôs, a fim de testar sua eficiência em relação a falhas na realização de tarefas. Em seguida, foi utilizada a técnica de inquirição contextual (Holtzblat, 2004). O método constitui na abordagem de usuários de robôs de serviço, através de entrevistas e observação, com análise dos processos de trabalho, atividades e problemas gerais na interação com sistemas a partir de sua interface. Nas entrevistas, foram coletadas informações gerais sobre o contexto de uso e diferentes aspectos da interação. Por fim, testes de usabilidade foram conduzidos para avaliar a validade de diretrizes para interfaces robóticas, a fim de comprovar a hipótese de pesquisa, de que se interfaces específicas para sistemas robóticos forem concebidas considerando as especificidades dos modelos de interação humano-robô, as falhas operacionais na interação serão reduzidas. A construção do teste se deu a partir do cruzamento da análise da pesquisa bibliográfica com as informações obtidas nas entrevistas contextuais. 


\section{1. \\ Entrevistas Contextuais}

Conforme elucida Chizzotti (2000), a entrevista dirigida à determinada pessoa em pesquisa é um tipo de comunicação entre um pesquisador que pretende colher informações sobre fenômenos e indivíduos que detenham essas informações e possam transmiti-las. Segundo Prodanov e Freitas (2013) "as informações colhidas sobre fatos e opiniões devem constituir-se em indicadores de variáveis que se pretende explicar. É, pois, um diálogo preparado com objetivos definidos e uma estratégia de trabalho. "Para Marconi e Lakatos (2003), a entrevista é um procedimento utilizado na investigação social e seu principal objetivo é o de obter do entrevistado informações sobre um determinado assunto ou problema. É caracterizada por "um encontro entre duas pessoas para que uma delas obtenha informações sobre determinado assunto, mediante uma conversação de natureza profissional" (Marconi e Lakatos, 2003).

A entrevista ou inquirição contextual (Holtzblatt, 2003) acontece em encontros individuais realizados no espaço de trabalho do usuário (contexto), e se concentram nas observações do trabalho em andamento. Para conduzir esta inquirição, é necessário não só observar, mas também registrar o contexto de tarefas. $\mathrm{O}$ entrevistador analisa o que está acontecendo no exato momento da interação. Segundo Holtzblatt (2003), o objetivo é entender usuários e gerar ideias para novas direções de um sistema. Como parte da pesquisa exploratória, sua escolha como método de pesquisa ofereceu a chance de aumentar a familiaridade da pesquisadora com o assunto e também clarear conceitos já estabelecidos no processo observado.

Na prática, essas entrevistas permitiram melhor compreensão do contexto de uso de RUIs além de formular ideias para os testes de usabilidade. Ao observar a interação entre usuários e operadores de diferentes sistemas robóticos, o pesquisador se comporta como aprendiz enquanto o usuário é seu mestre, lhe explicando tudo aquilo que é necessário saber para operar o robô em questão. Existem muitas formas de utilizar robôs, e por isso, a inquirição contextual propiciou observar propósitos de uso variados, possibilitando o entendimento de robôs em diferentes contextos de ação. A partir destas observações, a pesquisa 
buscou compreender as especificidades de interação para posteriormente relacionalas com regras que possam acentuar sua usabilidade.

\subsection{1. Sujeitos da Entrevista}

De acordo com Cooper et al. (2014), para se planejar uma entrevista é necessário que o pesquisador identifique uma amostra diversificada de usuários para capturar uma gama de comportamentos em relação a um produto. Por isso, na pesquisa foram entrevistados usuários que lidam com robôs tanto no ambiente de pesquisa acadêmica quanto em serviços, a fim de obter uma amostra relevante e diversa. Os candidatos foram recrutados no ambiente acadêmico, profissional e também doméstico, na Pontifícia Universidade Católica (PUC-Rio) e na Universidade Federal do Rio de Janeiro (UFRJ), através do contato com laboratórios ligados a pesquisa de mecatrônica, design e robótica.

\subsection{2. \\ Procedimento de Entrevistas}

A inquirição ou entrevista contextual desta pesquisa foi composta de três partes: planejamento, execução e interpretação. O planejamento descreve as características dos participantes, materiais utilizados e locais de entrevista. O procedimento aconteceu no ambiente de trabalho onde o usuário utilizava o robô permitindo a observação direta do contexto real de uso. Já as sessões de interpretação das entrevistas ocorreram posteriormente com um grupo de voluntários que auxiliam a pesquisadora na análise dos dados coletados.

\subsubsection{1.}

\section{Planejamento}

No planejamento da técnica o pesquisador deve buscar sob a perspectiva de aprendiz obter do entrevistado (a) toda informação necessária para utilizar o robô em questão. Por isso, deve-se estar focado na tomada de decisão do entrevistado, bem como tomar parte na discussão e buscar confirmar suas descobertas ao oferecer 
insights, ideias e interpretações das atividades observadas. Em um primeiro momento é importante se certificar que o ambiente da entrevista está preparado; câmeras, gravadores de áudio, máquinas fotográficas ou quaisquer outros dispositivos selecionados para a captura de informação devem estar prontos para o uso. O pesquisador se apresenta ao entrevistado, falando brevemente do estudo, os objetivos do projeto e quais serão os métodos utilizados da entrevista. Posteriormente, é descrita a política de confidencialidade, pontuando a atividade de entrevista contextual em questão, e pedindo permissão para que a informação acolhida seja usada para fins acadêmicos. A partir deste ponto é sinalizado o início da entrevista. Todos esses procedimentos foram seguidos pela pesquisadora no planejamento da técnica.

\subsubsection{2.}

\section{Execução}

A pesquisadora conduziu a entrevista sob a condição de aprendiz e procurou capturar os aspectos essenciais da utilização em questão (Figura 6.1). Para isso, efetuou o procedimento explicitado no quadro a seguir (Quadro 6.1) onde tomou nota de tudo que considerou importante, buscando compreender os objetivos identificados, meios e artefatos utilizados, assim como quais foram os principais comportamentos identificados, seu fluxo de tarefas, e os requisitos básicos de utilização. A dinâmica aconteceu de forma descontraída, e a entrevistadora buscou incentivar o entrevistado a apresentar brevemente seu contexto de uso e métodos utilizados, pedindo também que relatasse histórias e exemplos práticos de funcionamento (Apêndice C). Foi importante saber do usuário:

- O que ele ou ela considerava importante na utilização?

- O que poderia dar errado ou não funcionar da forma esperada?

- Como reagir ou mitigar questões operacionais relacionadas a falhas?

- Quais atalhos para solucionar questões?

Quadro 6.1 - Descrição do procedimento de execução das entrevistas contextuais. 
Etapas da Entrevista Contextual

Introdução (até 10 minutos)

Apresentação da entrevistadora, o objetivo do projeto e o método que será utilizado;

As expectativas que se tem para a entrevista

Descrição sobre a política de confidencialidade e coleta de assinatura do entrevistado (Apêndice I)

Transição (2 minutos)

Apontar a mudança do convencional para o contextual: passagem para o modo 'mestre/ aprendiz'.

Abordagem (entre $1 \mathrm{~h}$ e 1,5h)

Compreender as razões nas tomadas de decisões do usuário em relação a suas tarefas - o que motiva os comportamentos dos indivíduos em diferentes contextos e uso e como eles esperam alcançar seus objetivos; Registrar tarefas e atividades em um bloco de notas para interpretações (individual e em grupo) em sessões posteriores.

Conclusão

Fazer uma interpretação ampla do que foi aprendido se certificando de que não faltou nada. Pedir para seu entrevistado uma breve apresentação de sua função e papel na organização assim como o motivo da utilização do robô em questão.

Agradecer a participação e recolher o material colhido durante a entrevista.

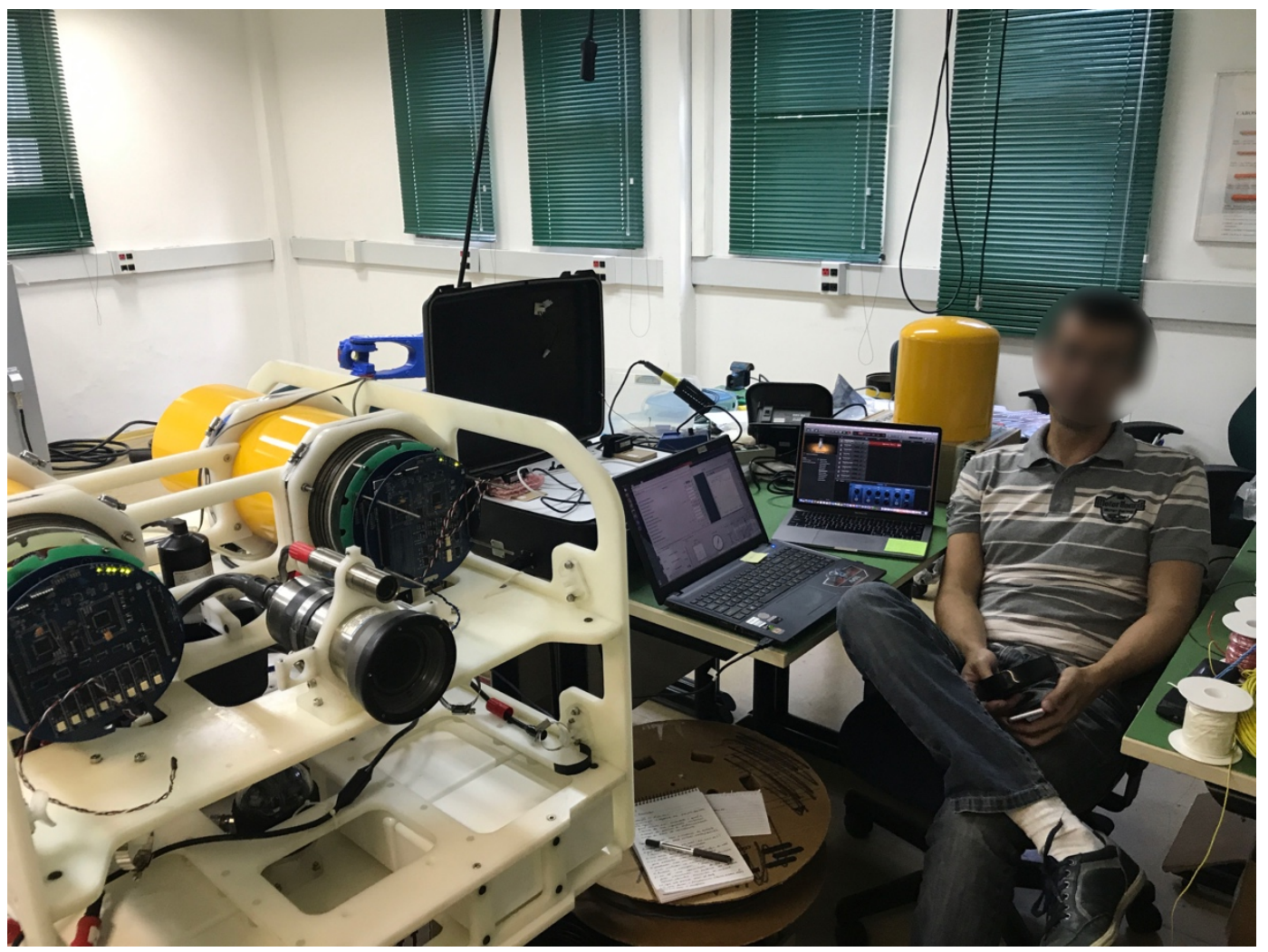

Figura 6.1 - Usuário do robô Luma durante a execução da entrevista contextual.

\subsubsection{3.}

\section{Interpretação}

Em seguida a execução das entrevistas, foram realizadas sessões de interpretação para capturar e analisar o conteúdo das entrevistas. Segundo 
Holtzblatt (2003), uma vez finalizada a entrevista o próximo passo é compartilhála com a equipe para interpretar o volume de informação capturado. Nesta pesquisa, as entrevistas foram conduzidas apenas pela pesquisadora que, em um primeiro momento de sua interpretação, organizou as notas e conteúdo capturados para posteriormente, compartilhá-las com uma equipe voluntária que variou entre três e quatro participantes para rever, analisar e capturar os dados revelados por cada usuário. As sessões ocorreram na semana seguinte às entrevistas e na atividade cada participante possuiu uma função diferente, a fim de ajudar no processamento da informação obtida. Segmentar as funções de cada participante de acordo com diferentes notas de captura (Quadro 6.2) permitiu a organização visual do conteúdo capturada em cada sessão (Figura 6.2).

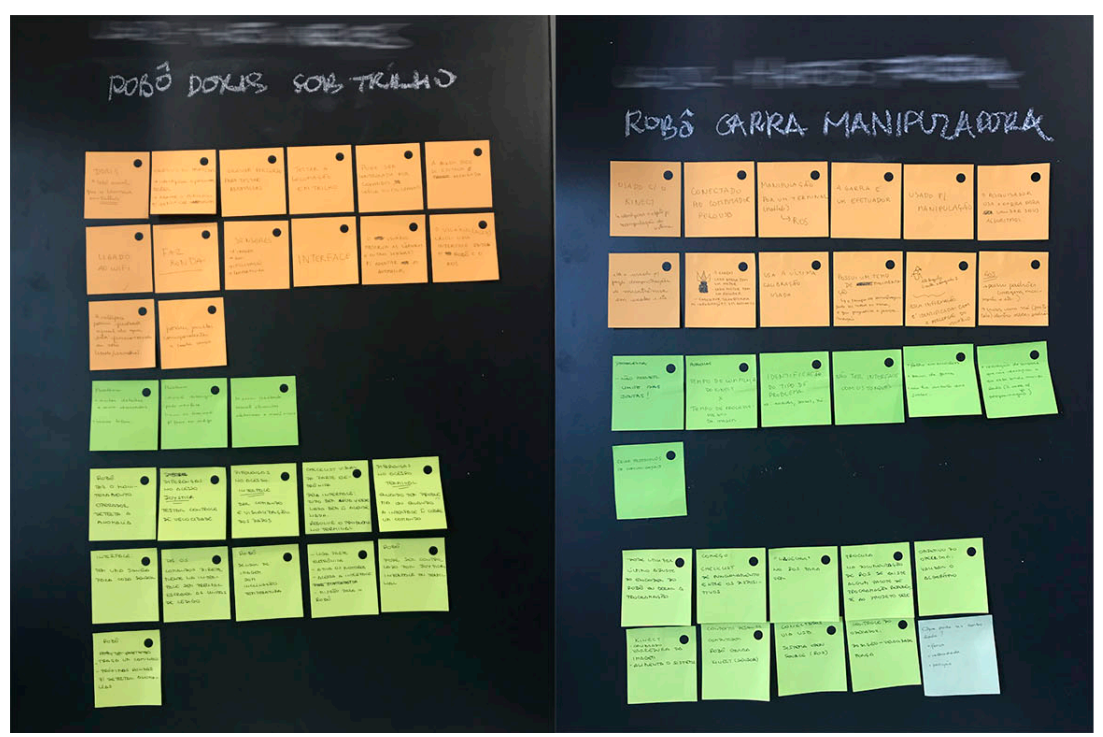

Figura 6.2 - Notas de capturadas ao fim de sessões de interpretação de acordo com o foco de cada participante.

Quadro 6.2 - Notas de capturadas ao fim de sessões de interpretação de acordo com o foco de cada participante.

\begin{tabular}{|c|}
\hline Interpretação da Entrevista Contextual \\
\hline Parte 1: Análise de informações colhidas \\
\hline $\begin{array}{l}\text { Apresentação da entrevistadora, o objetivo do projeto e o método que será utilizado; } \\
\text { As expectativas que se tem para a entrevista } \\
\text { Descrição sobre a política de confidencialidade e coleta de assinatura do entrevistado (Apêndice I) }\end{array}$ \\
\hline Parte 2: Sessão interativa com outros pesquisadores \\
\hline $\begin{array}{l}\text { Compartilhar entrevistas com os pesquisadores, apresentar fatores importante observados e questões } \\
\text { relevantes. } \\
\text { Ter como backup todo o material selecionado para apontar observações } \\
\text { Segmentar funções de acordo com notas de captura, ou seja, os participantes estarão focados em aspectos } \\
\text { para classificação da informação como: (a) modelos de trabalho; (b) ideias de design; (c) insights de captura; } \\
\text { (d) problemas. }\end{array}$ \\
\hline
\end{tabular}




\subsection{3.}

\section{Coleta e análise de dados}

A coleta de dados foi feita a partir da análise do material capturado nas entrevistas e sessões de interpretação. Como parte da metodologia de pesquisa, estas entrevistas revelaram falhas mais comuns observadas na interação com robôs, permitindo uma confirmação dos apontamentos feitos na literatura, bem como novas descobertas. A análise destas falhas permitiu a observação de contextos em que diretrizes de design poderiam ser testadas para avaliar sua usabilidade e, consequentemente, medir a variável dependente.

Partindo de uma perspectiva ampla, e sabendo que a categoria de robôs de serviços abrange todos os robôs que não são destinados ao uso industrial, prestando serviços de utilidade e bem-estar aos seres humanos, a maior parte das entrevistas foi feita com usuários de robôs em ambiente de pesquisa e RUI's em desenvolvimento. Analogamente, foram realizadas entrevistas com usuários de robôs de serviço já disponíveis ao consumidor como o Roomba e o DJI (Figura 6.3). No caso do Roomba, foi possível observá-lo tanto em sua utilização em pesquisa quanto doméstica. Esta diferenciação permitiu também que se avaliasse a abordagem de interfaces já consolidadas no mercado em relação a falhas de interação comuns. A amostra de robôs das entrevistas foi composta por:

Quadro 6.3 - Tipos de robôs avaliados nas entrevistas contextuais.

\begin{tabular}{|c|c|c|c|}
\hline NOME & TIPO & fins de pesquisa & fins comerciais \\
\hline MH08 & braço robótico & & \\
\hline Roomba & aspirador & & \\
\hline Garra & manipulador & & \\
\hline Doris & móvel sob trilhos & & \\
\hline Luma & submarino & & \\
\hline DJI & drone voador & & \\
\hline
\end{tabular}


As informações coletadas foram reunidas e agrupadas de acordo com as seguintes categorias: notas gerais, modelos de trabalho, problemas de interação e ideias de design. Esta categorização permitiu a seleção dos dados com propósito definido. As notas gerais e modelos de trabalho serviram como referência para pesquisadora no que se refere à familiarização com os processos de utilização dos robôs e ao contexto de uso. Os problemas de interação serviram para estabelecer uma relação entre falhas apontadas em campo com as falhas de interação encontradas na literatura. Posteriormente, a análise das ideias de design serviu como referência na criação das interfaces utilizadas nos testes de usabilidade.

Ao analisar os dados relativos a problemas de interação, foi possível perceber que de fato as falhas descobertas durante as entrevistas em muito se relacionam com as falhas mais comuns apontadas na literatura. Os problemas encontrados foram relacionados a: (a) análise de múltiplas telas, (b) carga de trabalho no processamento de informação oriunda de diversos fontes e telas, muitas vezes necessitando uma síntese por parte do operador, (3) feedback com relação ao status do sistema (hardware e/ou software) e tempo de respostas entre comando e ação do robô.

\section{2 . Testes de Usabilidade}

Teste de usabilidade é um método para avaliar interfaces mediante a participação de usuários reais com um propósito definido. Conforme Barnum (2011, tradução nossa), o teste "permite que usuários reais acessem um produto para executar tarefas realistas dentro de seus objetivos de uso"7. No contexto da pesquisa, permitiu a captura de comentários e a observação da linguagem corporal (em muitos casos), para descobrir desejos e expectativas do usuário em relação ao produto, aprendendo como este se relaciona com os objetivos de uso em questão. $\mathrm{O}$ objetivo deste teste foi validar diretrizes específicas de design concebidas em acordo com o modelo de interação humano-robô. Para tanto, empregou-se o teste com uma RUI dando continuidade à confirmação ou a refutação da hipótese de

7 "usability testing which focuses in observing real users performing real tasks that are meaningful to them" Barnum (2011) 
pesquisa. O projeto de estruturação deste teste se baseou nas etapas estabelecidas por Rubin e Chisnell (2008).

Segundo Rubin e Chisnell (2008), o planejamento de teste serve para definir as ações que irão ocorrer durante o processo e sua metodologia deve ser composta de: propósito e objetivo do teste; questões do teste sob aspecto qualitativo e quantitativo; características dos participantes; o sistema avaliado; tarefas; ambiente de teste; equipamentos e logística; papel do moderador do teste; dados coletados e meios de avaliação; conteúdo do relatório e apresentação.

\subsection{1.}

\section{Proposta e objetivos}

A proposta do teste é validar diretrizes de design concebidas com intuito de melhorar a usabilidade de um sistema robótico. O teste teve como objetivo geral validar diretrizes específicas de design concebidas em acordo com o modelo de interação humano-robô. Para tanto, trabalhou-se com os seguintes objetivos específicos:

- Medir o desempenho de dois grupos de usuários e como eles interagem com dois tipos de interfaces para sistemas robóticos: (a) um tipo de interface que segue diretrizes de IHR pré-determinadas em literatura e (b) um tipo que interface sem a abordagem IHR;

- Relacionar a satisfação dos usuários com os dois tipos de interfaces.

\subsection{2.}

\section{Questões do Teste}

Esta etapa do plano do teste de usabilidade é considerada por Rubin e Chisnell (2008) a mais importante de todas, uma vez que descreve "os problemas e questões que precisam ser resolvidos na pesquisa, e nas demais atividades associadas ao planejamento, projeto e realização do teste". A clareza e objetividade nestas questões são essenciais para que os resultados obtidos possam ser quantificados e mensurados. Assim, as questões de teste buscaram responder se as interfaces com diretrizes de IHR, se comparadas às interfaces sem a aplicação de diretrizes, influenciam:

- Na completude das tarefas? 
- Na ocorrência de falhas de interação?

- No tempo de completude das tarefas?

- Na satisfação de usuários com o sistema?

As questões foram baseadas em concordância com as medidas de usabilidade de Eficácia, Eficiência e Satisfação. Para cada um destas, buscou-se saber:

\section{Eficácia}

Os participantes conseguiram completar cada tarefa?

Quão bem os participantes completaram as tarefas? Ou seja, qual foi nível de completude em cada tarefa?

\section{Eficiência}

Qual foi o tempo de completude de cada tarefa?

Quantas vezes foi necessário o retrabalho? (Em situações em que houve erro de execução e o participante precisou voltar para corrigi-lo - exemplos desses erros serão explicados a seguir.)

\section{Satisfação}

Qual das duas interfaces teve um maior índice de satisfação sob o ponto de vista dos participantes?

\subsection{3.}

\section{Características dos participantes}

O critério principal de escolha para seleção de participantes dos testes de usabilidade foi possuir experiência de interação com sistemas robóticos. Por sistemas robóticos entende-se robôs de serviço, como robôs móveis, submarinos, drones e correlatos. Todos os robôs em questão podem ser operados remotamente via interface gráfica de usuário. Os participantes foram recrutados no Laboratório de Controle e Automação, Engenharia de Aplicação e Desenvolvimento, o LEAD da UFRJ, e no laboratório de Interfaces Físicas Experimentais, o LIFE na PUC-Rio. No total, doze participantes foram divididos randomicamente em dois grupos de seis participantes num modelo de teste entre-sujeitos, ou seja, foram distribuídos independente de seus laboratórios de origem e cada grupo realizou o teste em apenas uma das interfaces. 


\subsection{4. \\ Método do Teste}

Este teste de usabilidade buscou identificar se há relação entre duas variáveis, (a) independente: as interfaces de sistemas robóticos com e sem abordagem HRI e (b) dependentes: usabilidade das interfaces na interação dos usuários com sistemas robóticos.

As sessões de teste foram realizadas no contexto de uma interação remota, via computador desktop, utilizando como base o sistema robótico de manutenção de turbinas $\mathrm{EMMA}^{8}$. O sistema Emma é um sistema robótico em desenvolvimento, que atua na manutenção de turbinas in situ. A escolha de utilizar tal sistema se deu por conveniência, visto que a autora trabalha como designer de interfaces no âmbito de pesquisa e desenvolvimento e tem acesso aos requisitos de funcionamento do sistema.

As interfaces foram criadas no software Justinmind, uma ferramenta para prototipagem de aplicativos para web e wireframes de alta fidelidade. Desta forma, foram desenhadas interfaces para dois diferentes testes, e um aplicativo do sistema EMMA, com objetivo de orientar participantes sobre o funcionamento do sistema e de apresentar as tarefas a serem executadas no teste. Os testes 1 e 2 compõem duas versões de interface para o sistema EMMA, sendo suas tarefas apresentadas de forma distinta em cada teste, com ou sem a aplicação das diretrizes selecionadas. O teste 1 foi o teste desenhado sem aplicação de diretrizes, enquanto o teste 2 foi desenhado de acordo com as diretrizes HRI.

\subsection{5.}

\section{Sobre o EMMA}

O EMMA realiza manutenção de turbinas em usinas hidrelétricas dentro de seus ambientes operacionais. O sistema é formado por um braço robótico que opera sobre trilhos, sensores para medições externas, além de uma estrutura mecânica que dá suporte ao aparato robótico. Para fins do teste, o aplicativo informativo cumpriu duas funções. A primeira de explicar aos participantes o propósito do sistema e as tarefas a serem realizadas. A segunda, foi de replicar características de interação

${ }^{8}$ O EMMA é um sistema robótico desenvolvido pela empresa 13 Robotics, que tem o objetivo de reparar de turbinas In Situ no ambiente de turbinas de bulbo em usinas hidrelétricas. 
com sistemas robóticos, que exigem do operador a interação com múltipla telas e acesso a outras fontes de dados referentes a operação a ser executada. $\mathrm{O}$ aplicativo informativo foi então visualizado em um tablet permitindo que participantes acessassem informações do sistema (Figura 6.3 e 6.4) e suas as tarefas (Figura 6.5) a qualquer momento durante o teste.

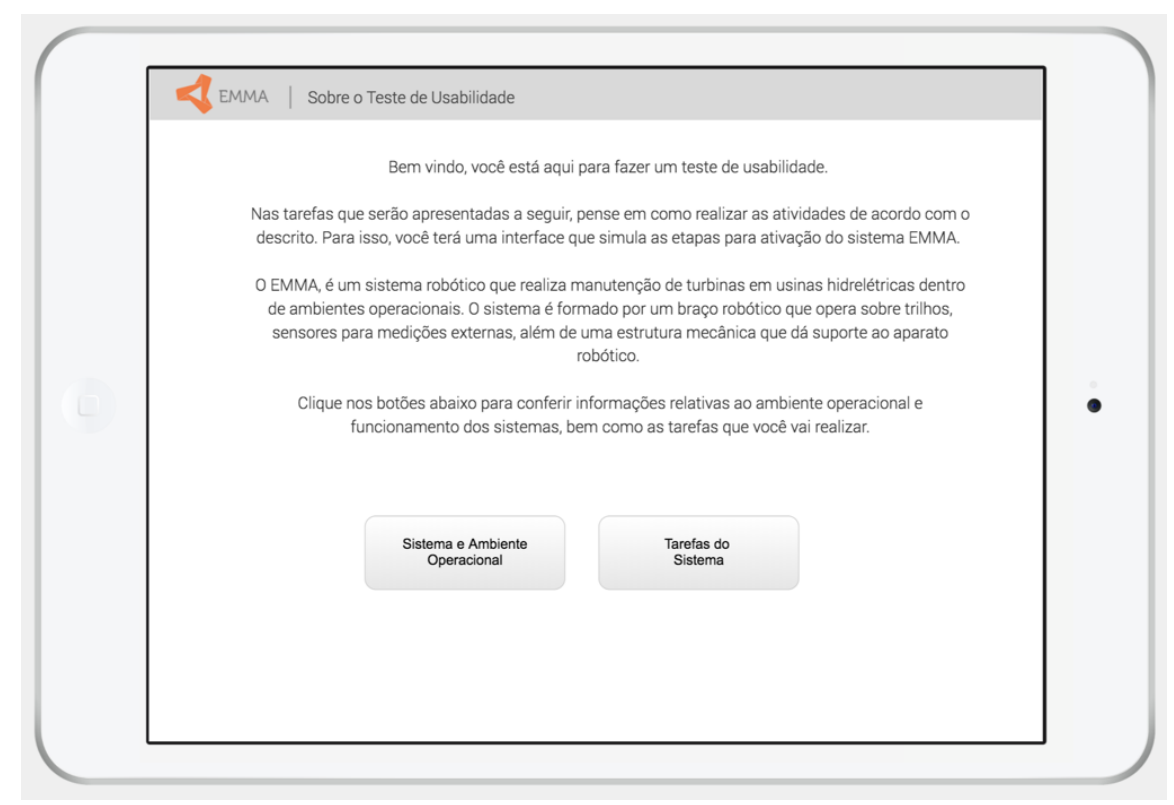

Figura 6.3 - Apresentação do aplicativo com informação sobre o sistema e suas tarefas.

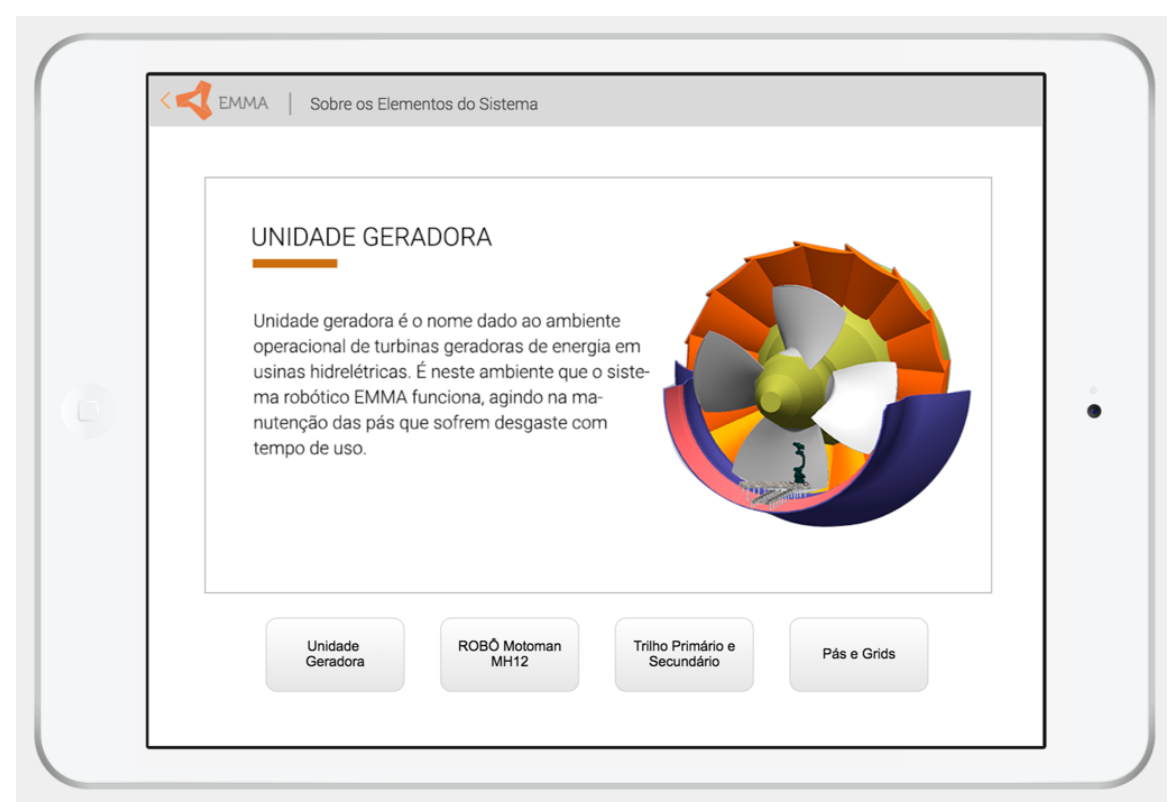

Figura 6.4 - Tela do aplicativo explicativa das partes que compõem o sistema EMMA. 


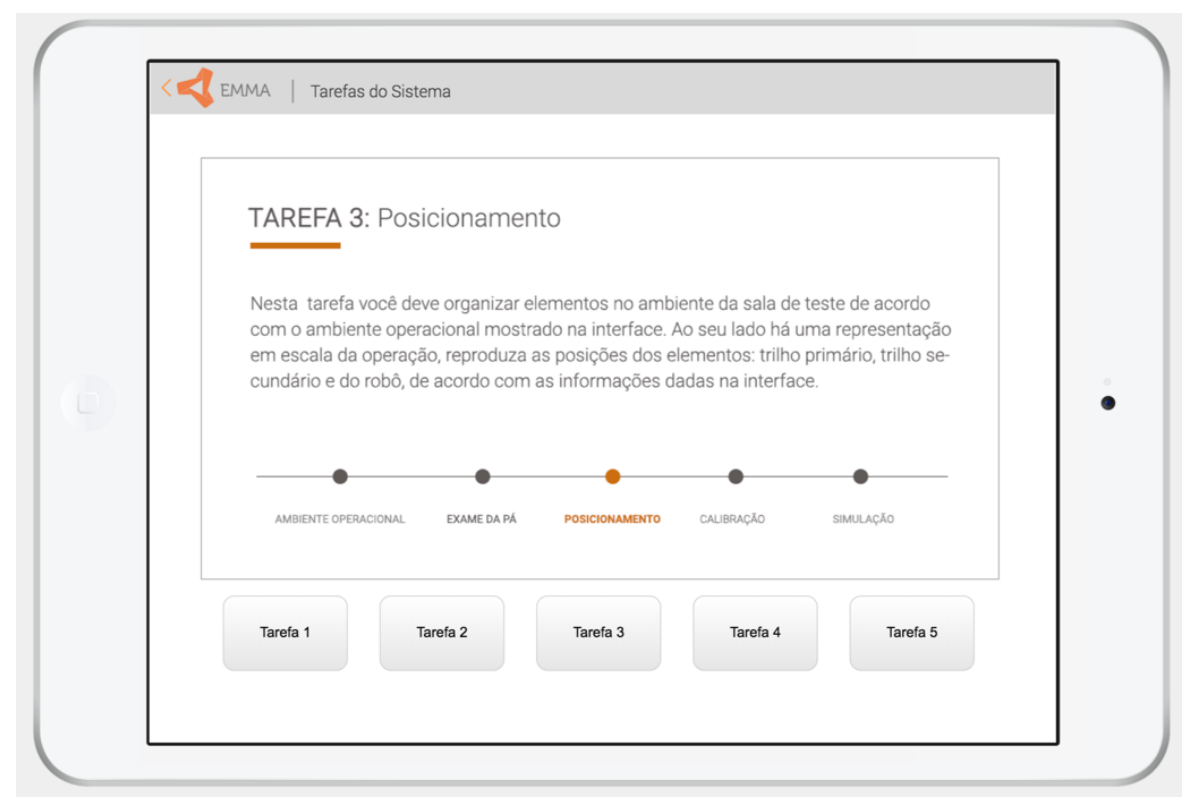

Figura 6.5 - Tela do aplicativo com informações sobre as tarefas a serem executadas.

\subsection{6.}

\section{Lista de tarefas}

O teste de usabilidade simulou a interação do operador com um robô remoto em seu ambiente de operacional. Esse cenário possibilitou que o teste ocorresse sem a necessidade de um robô de verdade, facilitando a logística e tornando o experimento mais seguro para os participantes. $\mathrm{O}$ participante executou, então, as ações em um computador desktop auxiliado por um tablet que disponibilizava informações sobre os procedimentos do teste, suas tarefas e informações do sistema EMMA.

\subsubsection{1.}

\section{Tarefa de parâmetros do ambiente operacional}

Nesta tarefa o participante deveria validar as informações de sensores que medem o ambiente dentro da unidade geradora. Para isso, ele deveria se certificar de que as informações relativas à temperatura, à umidade e à partículas de poeira, estivessem de acordo com os parâmetros de funcionamento do sistema indicados na interface. Esta tarefa foi apresentada nos dois testes de forma distinta de acordo com a aplicação ou não das diretrizes (Figuras 6.10 e 6.11).

Quadro 6.4 - Detalhamento da Tarefa 1. 
Validar a informação de sensores que medem o ambiente da operação.

\section{ATIVIDADES DA TAREFA}

1. Observar informações correspondentes aos parâmetros do sistema

2. Selecionar opção dizendo se o valor apresentado atende ou não aos parâmetros do sistema

3. Confirmar opções

4. Finalizar Tarefa

\section{Diretriz Tarefa 1 - Projetar Informação apenas necessária}

A Informação fornecida ao usuário deve ser objetiva e evitar sínteses mentais. Nesta diretriz, entende-se que na interação com robôs a interface deve ser projetada para transmitir ao usuário informações apenas o suficiente para que seja possível determinar se a intervenção é necessária ou não, além de evitar a sobrecarga mental. Esta diretriz foi usada com intuito de abordar falhas relacionadas à leitura de sensores diversos para tomada de decisão na interação com robôs. Assim, entendese que, para o usuário, quanto menos esforço for demandado para adquirir a informação necessária melhor.

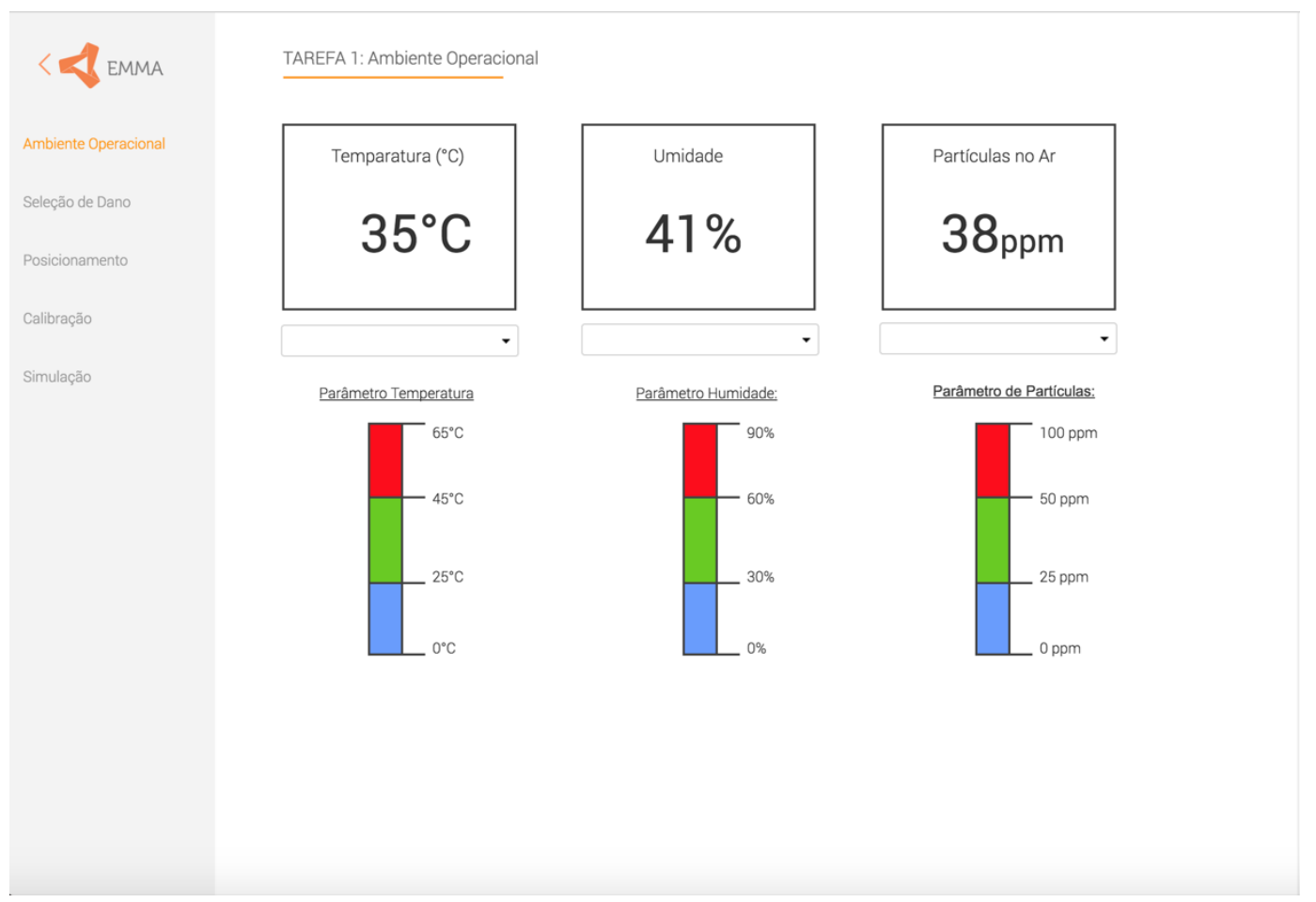

Figura 6.6 - Interface da tarefa 1 no Teste A, sem diretrizes para RUIs. 


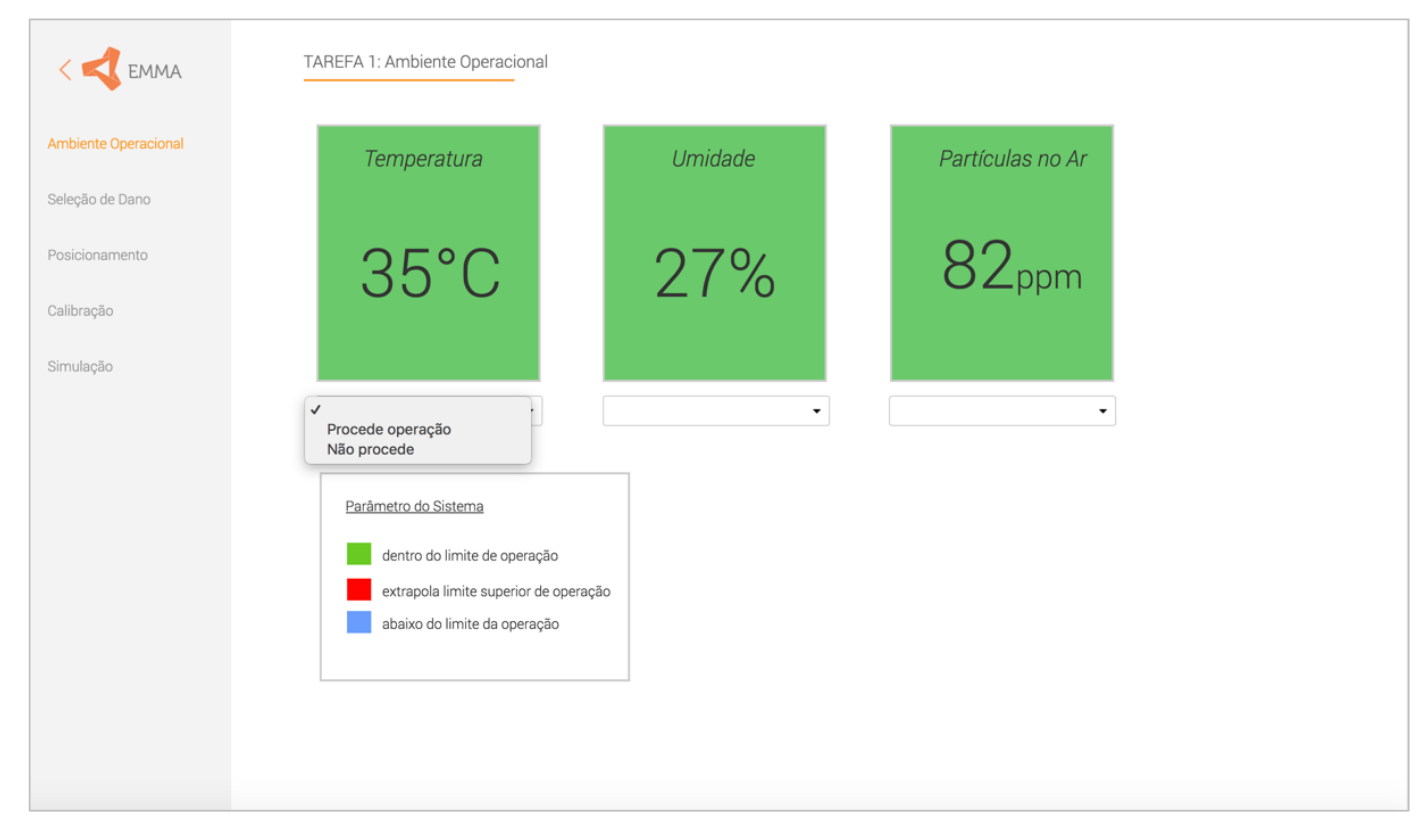

Figura 6.7 -Interface da tarefa 1 no Teste B, com diretrizes para RUIs.

\subsubsection{2.}

\section{Tarefa de exame de dano da pá}

Nesta tarefa, o usuário deveria selecionar a área do grid onde o dano se encontrava para a execução do revestimento. Para isso, ele observaria a imagem da pá e, em seguida, indicaria na interface a área específica do grid que deveria ser reparada (Quadro 6.5). Esta tarefa foi subdividida em duas telas: a primeira, que mostrava a pá com dano, era a mesma para ambos testes (Figura 6.8); porém, na tela seguinte, a seleção desta área era apresentada de forma distinta de acordo com a aplicação ou não das diretrizes (Figura 6.9 e 6.10). 


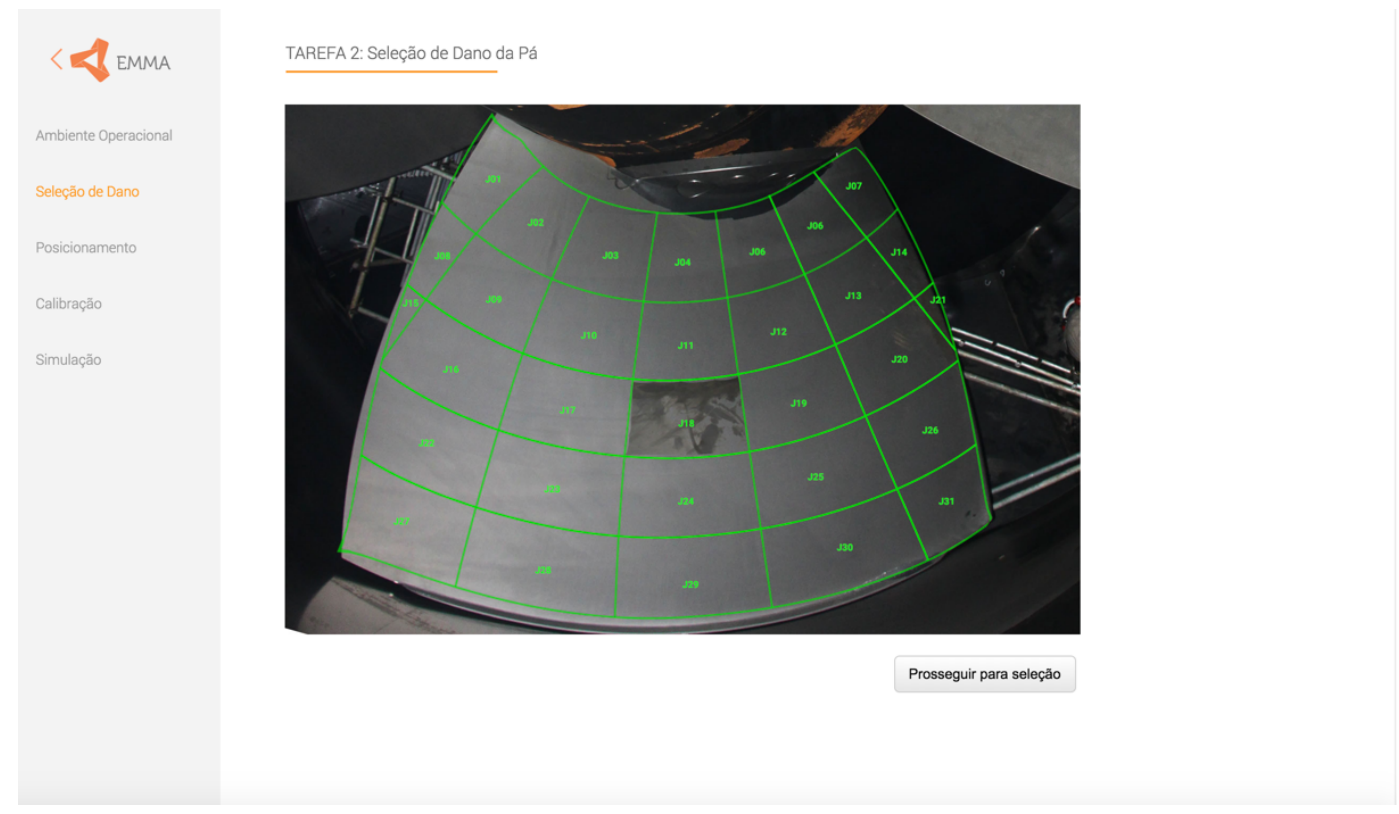

Figura 6.8 - Primeira tela da tarefa 2 era a mesma em ambos os testes

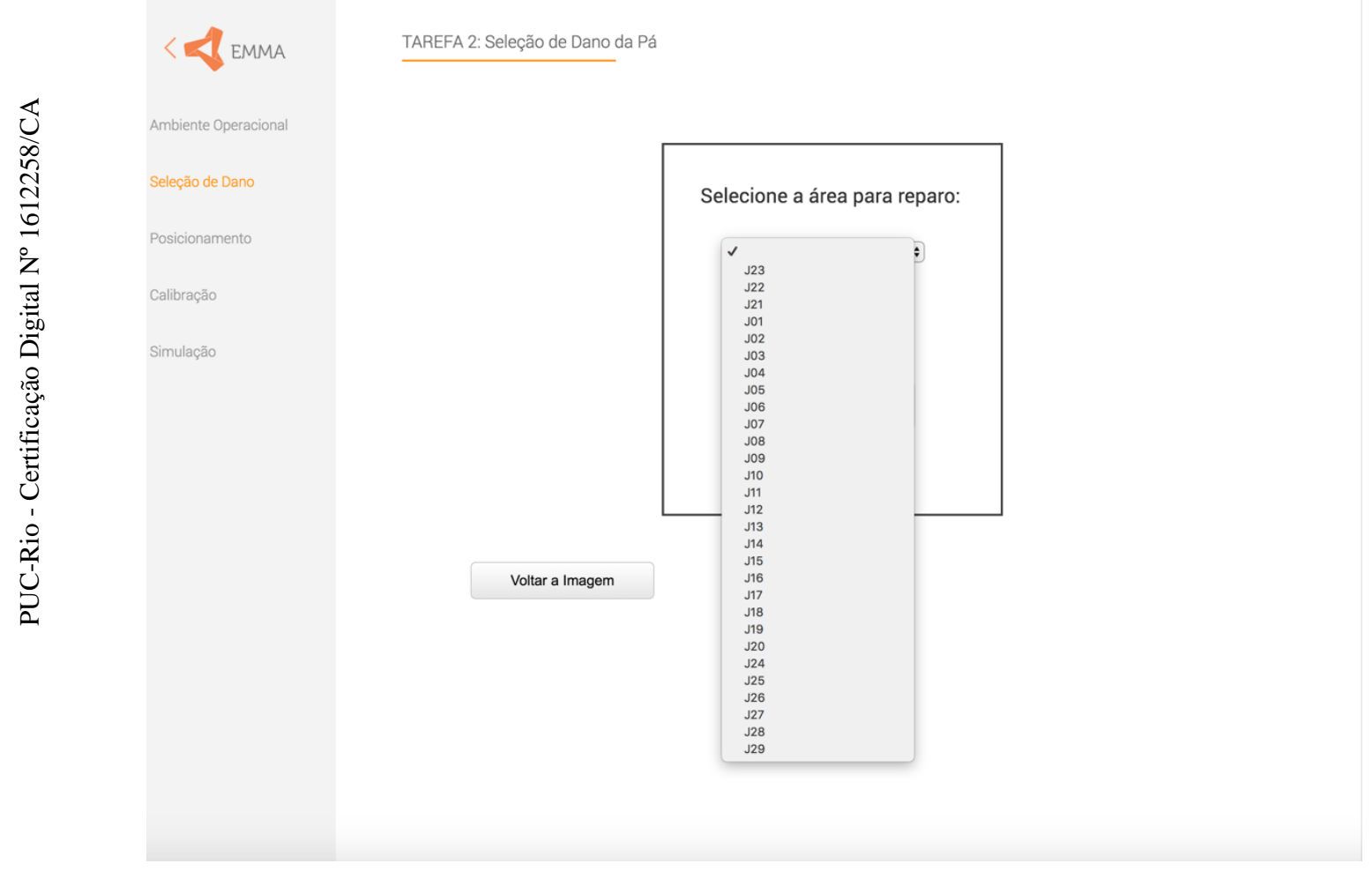

Figura 6.9 - Segunda tela da tarefa 2 no Teste A. 


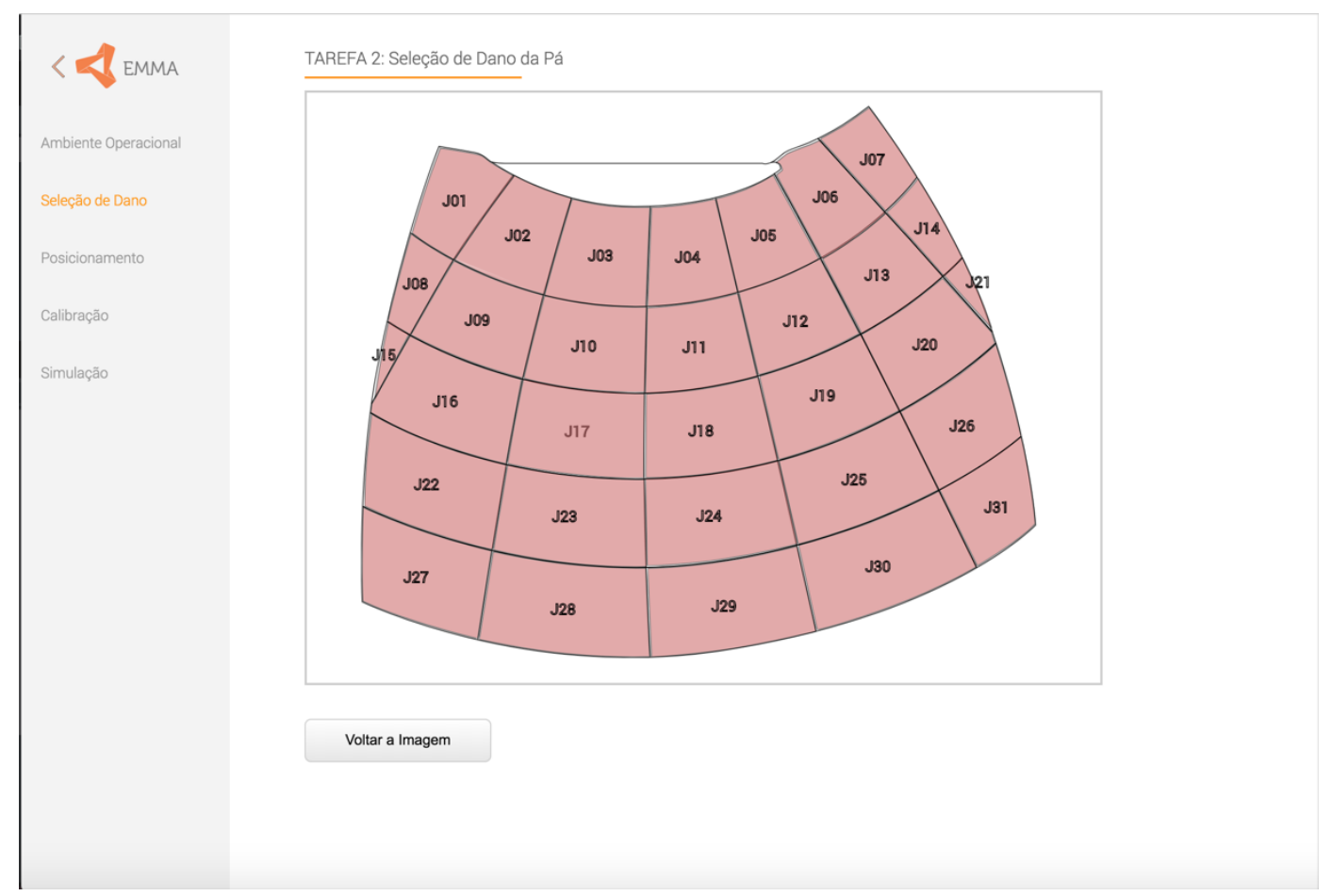

Figura 6.10 - Segunda tela da tarefa 2 no Teste B.

Quadro 6.5 - Detalhamento da Tarefa 2.

OBJETIVO DA TAREFA

Validar a informação de sensores que medem o ambiente da operação.
ATIVIDADES DA TAREFA

1. Observar informações correspondentes aos parâmetros do sistema

2. Selecionar opção dizendo se o valor apresentado atende ou não aos parâmetros do sistema

3. Confirmar opções

4. Finalizar Tarefa

\section{Diretriz Tarefa 2: Compatibilidade entre mundo real e a interface}

A diretriz utilizada como parâmetro de uma melhor interação com o sistema robótico foi a de tornar o status do sistema visível, oferecendo feedback visual ao usuário em relação a sua decisão. $\mathrm{O}$ sistema deve sempre manter os usuários informados sobre o que está acontecendo, por meio de feedback adequado, dentro de um prazo razoável. Essa diretriz foi escolhida como resposta a falhas relacionadas a falta de feedback do sistema para ações realizadas ou para o funcionamento do sistema. O objetivo desta diretriz é transmitir um modelo mental ao usuário que invoque compreensão completa do sistema. 


\subsubsection{3.}

\section{Tarefa de Posicionamento}

Nesta tarefa, o participante posicionaria os elementos no ambiente operacional reproduzido na sala de teste, de acordo com a informação mostrada na interface. $\mathrm{Na}$ frente do participante (Figura 6.11), havia uma representação em escala da operação onde se deveria reproduzir as posições dos elementos: trilho primário, trilho secundário e a base do robô, de acordo com as informações fornecidas na interface (Figuras 6.12).

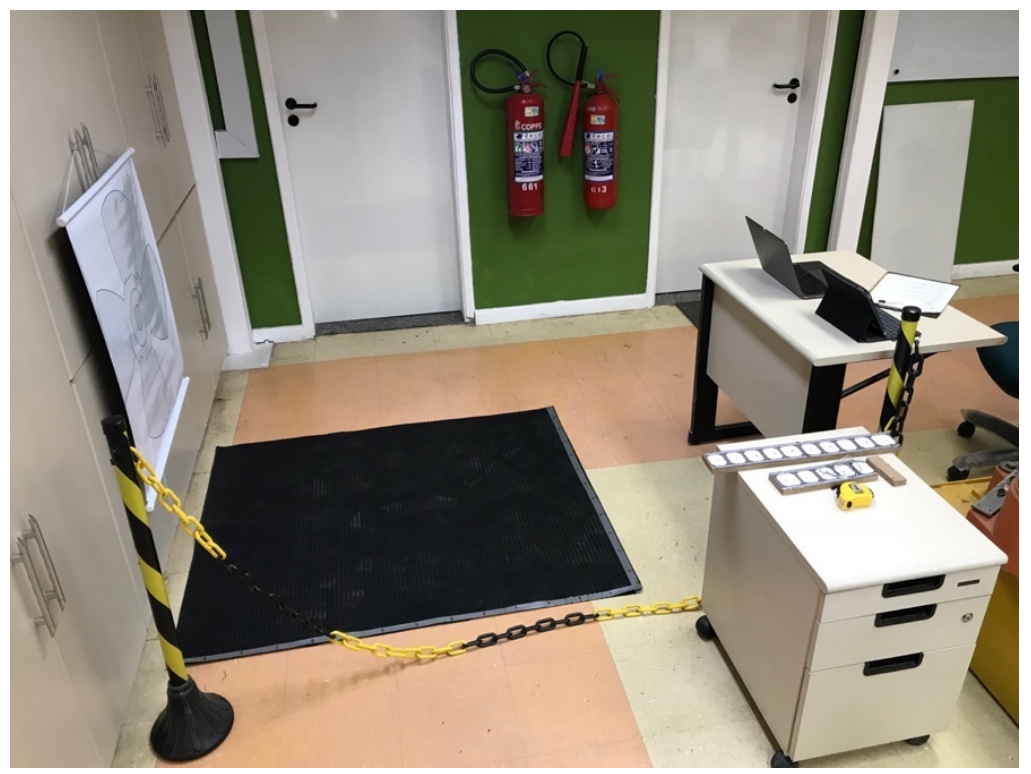

Figura 6.11 - Ambiente de teste com uma representação do ambiente operacional em escala e posicionado a frente do participante. 


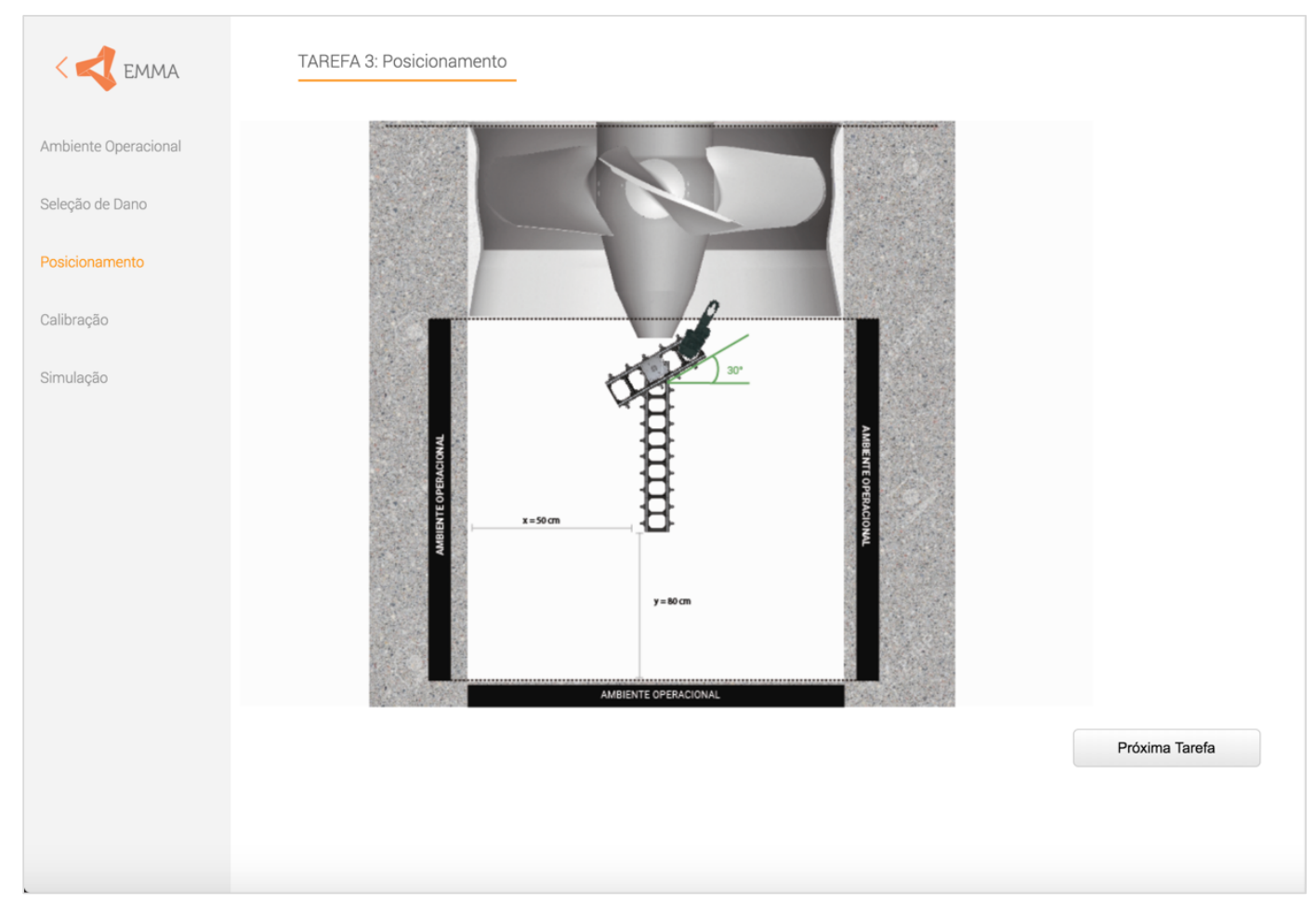

Figura 6.12 - Tela da tarefa 3 com informações para posicionamento dos elementos da operação.

Quadro 6.6 - Detalhamento da Tarefa 3.

OBJETIVO DA TAREFA

Reproduzir ambiente operacional do robô na sala de testes (mundo real), de acordo mostrado na interface (mundo do robô).
ATIVIDADES DA TAREFA

1 Observar informações dadas sobre o ambiente 2. Utilizar os elementos correspondentes aos elementos da operação, disponíveis fisicamente na sala de testes.

3. Após organizá-los no ambiente confirmar posições

\section{Diretriz Tarefa 3 - Aumentar a informação sobre o ambiente do robô}

A diretriz de IHR medida nesta tarefa é a de que o sistema deve procurar aumentar informação sobre ambiente operacional do Robô, a fim de tornar operadores mais conscientes dos arredores imediatos aos robôs. Essa diretriz foi escolhida como resposta a erros relativos à falta de informação sobre o espaço de trabalho do robô. 


\subsubsection{4.}

\section{Tarefa de Calibração}

Nesta tarefa, o participante deveria confirmar se as posições dos elementos da operação no ambiente externo estavam de acordo com os parâmetros fornecidos pelo sistema. Para isso, a tarefa de calibração faz a comparação de informações obtidas por sensores externos, com as informações mostradas na interface, a fim de se certificar se a operação pode prosseguir.

Quadro 6.7 - Detalhamento da Tarefa 4.

\begin{tabular}{l|l}
\hline \multicolumn{1}{c}{ OBJETIVO DA TAREFA } & \multicolumn{1}{c}{ ATIVIDADES DA TAREFA } \\
\hline & \\
\hline $\begin{array}{l}\text { Confirmar se as posições dos } \\
\text { elementos da operação no } \\
\text { ambiente operacional estão de } \\
\text { acordo com os parâmetros do } \\
\text { sistema. }\end{array}$ & $\begin{array}{l}\text { 1. Comparar informação apresentada de acordo } \\
\text { com posicionamento da tarefa anterior. }\end{array}$ \\
& $\begin{array}{l}\text { 2. Certificar-se de que o posicionamento está } \\
\text { correto }\end{array}$ \\
& 3. Prosseguir com operação \\
& \\
\end{tabular}

\section{Diretriz Tarefa 4 - Visibilidade do status do sistema \& feedback visual}

A diretriz afirma que o mundo do robô deve ser projetado de forma similar ao entendimento do ser humano, seguindo convenções do mundo real, fazendo com que a informação apareça de forma natural e lógica na interface com usuário. Essa diretriz foi escolhida como resposta a erros relativos ao conflito entre modelo mental do usuário e o modelo oferecido pelo sistema.

\subsubsection{5.}

\section{Simulação}

Nessa tarefa, o participante assistiria um vídeo com simulação da atividade do robô para se certificar de que é feita sem paradas de funcionamento e cobrindo toda a área desejada. Ao final do vídeo, o participante informaria o que viu. Quadro 6.8 - Detalhamento da Tarefa 5. 


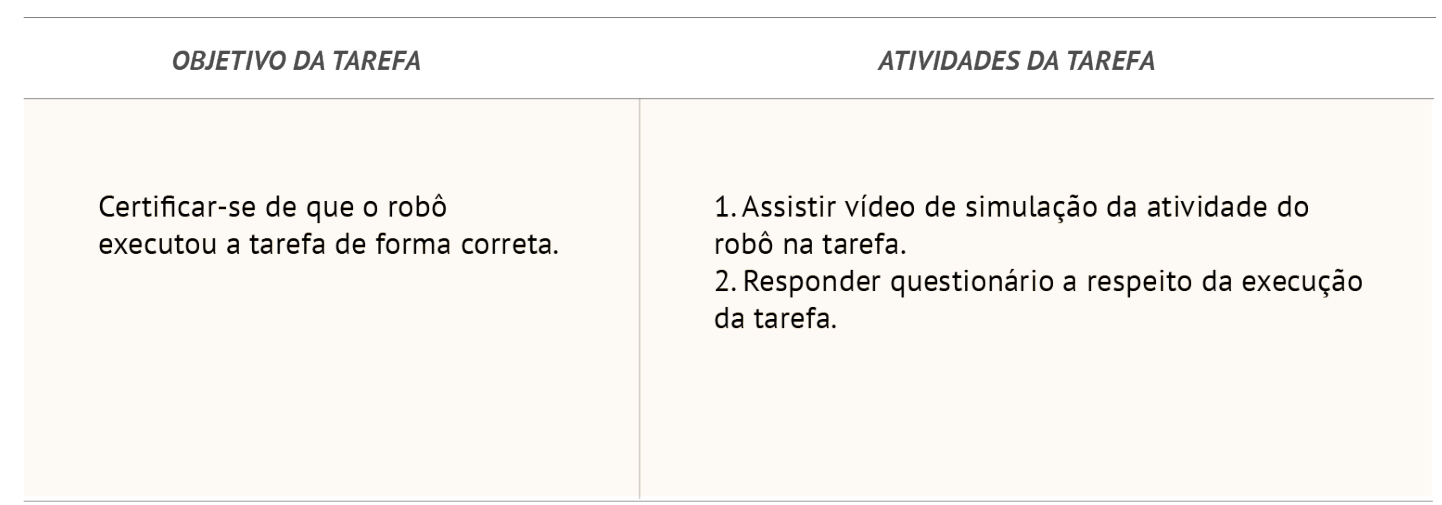

\section{Diretriz tarefa 5 - Ponto de vista compatível com usuário}

A projeção de mundo no sistema deve ser visualizada sob um ponto de vista compatível para o entendimento da tarefa, permitindo que o operador possa determinar se a intervenção é necessária ou não. Essa diretriz foi escolhida como resposta a visualizações de operação sob ângulos não muito claros ou eventualmente bloqueados por elementos do próprio sistema robótico mediante a situações não previstas.

\subsection{7.}

\section{Procedimento do Teste}

O quadro abaixo detalha como se deu o procedimento do teste.

Quadro 6.9 - Procedimento de teste. 
Arranjos pré-teste (5 minutos)

Moderador apresenta ao participante o termo de consentimento para ser lido e assinado, sendo dois documentos; um para ser guardado pelo moderador e outro para ficar em posse do participante.

\begin{tabular}{l}
\hline Apresentação do teste (5 minutos) \\
\hline Moderador mostra aos participantes os dispositivos utlizados no teste como câmeras para filmagem, gravador \\
de tela e os elementos físicos representam os elementos da operação no ambiente operacional. \\
Moderador mostra ao participante o aplicativo no tablet com todas as informações sobre o sistema robótico \\
utilizado, assim como a descrição e objetivo de cada tarefa.
\end{tabular}

Execução

Para o moderador:

Estar disponível para qualquer dúvida do participante, porém não o influenciar suas ações durante o teste.

Para participante:

Executar as tarefas de acordo com explicado, tendo ao seu lado um tablet com as informações do sistema

EMMA bem como as tarefas a serem realizadas.

SUS

\section{Para o moderador:}

Estar disponível para qualquer dúvida do participante e explicar eventuais duvidas.

Para participante:

Responder ao questionário e acordo com sua experiência com o teste recém acabado.

\subsection{8.}

\section{Ambiente e equipamentos do teste}

Foi utilizada uma configuração controlada para conduzir as sessões do teste. À disposição do participante, um laptop para realização do teste, um tablet com a informação referente ao sistema EMMA, as tarefas a serem realizadas, assim como elementos físicos representativos dos elementos operacionais do EMMA - robô, trilhos, e turbina - além de um tapete de borracha para demarcar o ambiente e um banner com a imagem da turbina em escala (Figura 6.9). Todas as sessões tiveram suas telas gravadas em vídeo através do Quicktime. A ideia foi de reproduzir um ambiente de interação remota e suas características. Após a realização das tarefas cada participante respondeu a um questionário SUS (System Usability Scale) ou sistema de Escala de Usabilidade, uma ferramenta rápida e confiável para medir usabilidade em interfaces. 


\subsection{9. \\ Dados coletados}

Para a análise dos dados obtidos, a pesquisa teve com base as medidas de usabilidade de eficiência, eficácia e satisfação. Em testes de usabilidade, os dados relativos ao desempenho têm como base as métricas de ações dos participantes. Essas medições variam tais como o tempo gasto em cada tarefa; o número de erros e a recuperação a partir destes; o sucesso ou fracasso na conclusão das tarefas; a contagem de passos e de ícones selecionados, dentre outros (Rubin e Chisnell, 2008; Barnum, 2010). Nesta pesquisa, foram selecionadas duas métricas de natureza quantitativa e uma qualitativa (Quadro 6.10). A expectativa foi a de que, uma vez estatisticamente validadas, a relação de satisfação dos participantes fosse medida por meio do questionário SUS.

Quadro 6.10 - Métricas de teste.

\begin{tabular}{c|c|c|}
\hline \multicolumn{1}{c|}{ MÉTRICA } & \multicolumn{1}{c}{ DADOS COLETADOS } & MÉTODO TRATAMENTO \\
\hline Completude da tarefa & $\begin{array}{l}\text { Sucesso ou fracasso na } \\
\text { conclusão da tarefa. }\end{array}$ & Contagem de erros durante a tarefa \\
\hline Contagem de erros & $\begin{array}{l}\text { Quantidade e natureza de } \\
\text { erros. }\end{array}$ & $\begin{array}{l}\text { Digitaçâo errada ou não encontrou } \\
\text { forma de executar a tarefa. }\end{array}$ \\
\hline Tempo de completude & $\begin{array}{l}\text { Tempo para completude ou } \\
\text { desistência da tarefa. }\end{array}$ & Contagem em minutos e segundos. \\
\hline Satisfação dos usuários com o & $\begin{array}{l}\text { Relato dos participantes e } \\
\text { sistema }\end{array}$ & SUS de satisfaçáa. \\
\hline
\end{tabular}

A definição de métricas foi crucial para o planejamento da análise de dados, a fim de averiguar as condições necessárias para validar as diretrizes de design específicas para interação com robôs.

\section{Completude de Tarefa e contagem de erros}

Como critério de análise de completude das tarefas, considerou-se 100\% para a completude bem-sucedida, sendo decrescida a porcentagem proporcional ao número de inputs de cada tarefa. Como exemplo, tem-se a Tarefa 4 , que continha 4 inputs: proporcionalmente a cada erro de input seriam decrescidos $25 \%$, contabilizados apenas no final, quando o participante anunciava ter completado a tarefa. Barnum (2010) afirma que é importante ouvir do participante o status de 
completude da tarefa, visto ser comum em estudos de usabilidade o sujeito achar, de modo equivocado, que a tarefa está completa. O participante pode concluir a tarefa de acordo com o enunciado, mas continuar além do ponto de conclusão para confirmar se o fizera corretamente. Desta forma, optou-se por contabilizar o sucesso ou fracasso da tarefa uma vez que seu término fosse anunciado pelo participante. Em situação de desistência, o participante receberia a nota zero relativa ao fracasso na completude.

Outro critério adotado foi o relativo aos tipos de erros na execução de tarefas. Foram dois, sendo o primeiro tipo se refere ao input de valor errado na interface, que está relacionado à atenção do usuário com relação aos dados fornecidos. $\mathrm{O}$ segundo está relacionado com o entendimento da navegação no sistema, se o usuário não encontrou caminhos na interface para executar a tarefa.

\section{Tempo de Completude}

O tempo de completude de tarefas foi medido formalmente durante o teste. Uma vez terminada a tarefa, os participantes eram instruídos a avisar verbalmente sua completude ao mediador, que assim possibilitava a contagem em minutos e segundos do tempo gasto com cada tarefa.

\section{System Usability Scale (SUS)}

O formulário (SUS) consiste em um questionário de dez itens com cinco opções de resposta para os respondentes; desde a concordância total até a discordância total. Tal questionário permite avaliar uma grande variedade de produtos e serviços, incluindo hardware, software, dispositivos móveis, sites e aplicativos. Sua escolha se deu em virtude de funcionar como uma ferramenta eficiente e confiável para comparar a usabilidade de duas interfaces a partir de uma análise subjetiva dos participantes. Através do SUS os participantes mostraram sua satisfação com a qualidade do sistema e a forma com o teste foi apresentado.

Para computar os resultados do teste é utilizado o seguinte critério: para itens ímpares é subtraído um ponto da resposta do usuário (x - 1), enquanto para itens pares o valor $\mathrm{x}$ das respostas dos usuários é decrescido do número 5 (5- x). Nesta escala todos os valores de 1 a 5 (sendo cinco a resposta mais positiva). Ao final do questionário, adiciona-se as respostas convertidas para cada usuário e se multiplica esse total por 2,5. Por fim, converte-se o intervalo de valores possíveis de 0 a 100. 
Como exemplo, o participante que responde uma questão ímpar com concordância total obtêm cinco pontos, que são decrescido de $1(\mathrm{x}-1$, no caso $5-1=4)$, resultando em 4 pontos a serem computados. Analogamente ao responder uma questão par com concordância total, é decrescido os 5 pontos do valor 5 , no caso resultando em $0(5-\mathrm{x}$, no caso $5-5=0)$.

\begin{tabular}{|c|c|}
\hline \multicolumn{3}{|c|}{ Pontuação SUS } \\
\hline 92 & Melhor imaginado \\
\hline 85 & Excelente \\
\hline 72 & Bom \\
\hline 52 & OK/Justo \\
\hline 38 & Pobre \\
\hline 25 & Pior possível \\
\hline $90-100$ & A \\
\hline $80-89$ & B \\
\hline $70-79$ & C \\
\hline $60-69$ & D \\
\hline Menos de 60 & F \\
\hline
\end{tabular}

Tabela 6.1 - Procedimento par resultados do questionário SUS. (Fonte:https://www.uxmastery.com/t/system-usability-scale-calculator)

\subsubsection{0. \\ Teste Piloto}

Os testes-piloto foram feitos com objetivo de determinar a validade do teste de usabilidade. Com o ambiente, os equipamentos e procedimentos definidos recrutou-se quatro participantes, de ambos Laboratórios LEUI da PUC e LEAD da UFRJ, e a configuração proposta foi replicada para a condução das sessões. Com a execução do roteiro de introdução, os pilotos foram instruídos a realizar as cinco tarefas do sistema EMMA propostas.

A apresentação das tarefas seguiu o roteiro do EMMA e, após sua conclusão, o feedback dos participantes ajudou a aprimorar o teste final. Questões levantadas incluíram uma melhor explicação do cenário operacional, já que muitas pessoas não possuem familiaridade com assunto de cunho técnico como o do EMMA, independente de sua familiaridade com sistemas e interfaces robóticas. Outro aspecto melhorado foi a informação e tratamento dos materiais físicos utilizados no teste com intuito de reproduzir a operação e seus elementos operacionais em escala 
no ambiente da sala de teste. Os objetos físicos que representam os elementos da operação, como trilhos e robô receberam referências numéricas, assim como o tapete que demarcou a área da operação, foi ornado com réguas laterais nos eixos $\mathrm{x}$ e y (horizontal e vertical respectivamente) para orientar os usuários de forma cartesiana, similar ao ambiente exibido na interface dos testes. Por fim, a cor do revestimento feito pelo robô no vídeo foi modificada de vermelho para azul, uma vez que usuários associaram o vermelho com mau funcionamento do sistema. 


\section{7 \\ Resultados}

A metodologia de pesquisa foi composta de revisão bibliográfica, entrevistas contextuais e de teste de usabilidade. O resultado das entrevistas contextuais foi pré-requisito para a realização dos testes de usabilidade, uma vez que as falhas mais comuns observadas na interação com RUIs - e coletadas nas entrevistas - serviram como fatores base para medir a usabilidade de interfaces com e sem a aplicação de diretrizes de HRI. Os testes de usabilidade avaliaram como usuários interagem com dois tipos de interfaces para sistemas robóticos: (a) um tipo de interface que segue diretrizes de HRI e (b) um tipo que interface sem a abordagem HRI. Posteriormente, relacionou-se a eficácia e a eficiência - o índice de completude das tarefas, a ocorrência de erros e o tempo de completude - e a satisfação dos usuários com os dois tipos de interfaces.

\section{1.}

\section{Análise dos Resultados das Entrevistas Contextuais}

As entrevistas foram divididas em duas etapas: a etapa prática quando a pesquisadora coletou os dados dos entrevistados, e a etapa de interpretação, que consistiu em uma sessão auxiliada por outros pesquisadores com o intuito de analisar o conteúdo sob uma perspectiva externa, garantindo a imparcialidade e a organização dos dados capturados. Para explorar a prática real e o desenvolvimento de tecnologia ligada a robôs, foi preciso estar em ambientes acadêmicos, laboratórios e/ou locais de trabalho onde estes projetos são ministrados e as interações ocorrem.

Foram entrevistados seis usuários de sistemas robóticos, responsáveis por sete tipos de robôs diferentes, entre os meses de Maio e Junho de 2017. Com a finalidade de selecionar as falhas de interação recorrentes experimentadas pelos usuários, os 
resultados foram tabulados durante as sessões de interpretação de (Apêndice 1). Todos os robôs investigados são operados remotamente via interface gráfica de usuário.

\subsection{1.}

\section{Robôs da pesquisa}

Esta pesquisa abordou tanto robôs de serviço já à venda em lojas de eletrônicos quanto robôs desenvolvidos no ambiente acadêmico de pesquisa, onde projetos são continuamente melhorados. Assim, foi possível investigar diferentes desde robôs móveis a robôs submarinos, robôs manipuladores e voadores. Ademais, o contato com o ambiente de desenvolvimento permitiu a compreensão da estrutura de trabalho com robôs, como estes sistemas integram diferentes dispositivos através do ROS e como plataformas opensource permitem constantes otimizações de códigos e colaboração entre desenvolvedores. As inquirições buscavam descobrir sobre a função do robô, o que é preciso para ativá-lo, seus modelos de trabalho e problemas de interação.

\section{Motoman MH08/Usuário 01}

Esta pesquisa abordou tanto robôs de serviço já à venda em lojas de eletrônicos quanto robôs desenvolvidos no ambiente acadêmico de pesquisa, onde projetos são continuamente melhorados. Assim, foi possível investigar vários deles, desde robôs móveis a robôs submarinos, robôs manipuladores e voadores. Ademais, o contato com o ambiente de desenvolvimento permitiu a compreensão da estrutura de trabalho com robôs, como estes sistemas integram diferentes dispositivos através do ROS e como plataformas Opensource permitem constantes otimizações de códigos e colaboração entre desenvolvedores. As inquirições buscavam descobrir sobre a função do robô, o que é preciso para ativá-lo, seus modelos de trabalho e problemas de interação.

\section{Motoman MH08/Usuário 01}

O Motoman é robô manipulador ou braço robótico. É amplamente utilizado em plantas industriais, ambientes de montagem. O MH08 abordado nesta pesquisa é utilizado no laboratório LEAD da UFRJ com intuito de validar diferentes 
estratégias algorítmicas (Figura 7.1). Em geral, estes robôs vêm de fábrica com ações e estratégias referentes ao seu funcionamento já estabelecidas. Ao utilizá-lo com intuito de pesquisa, eles são reprogramados e testados de acordo com algoritmos estabelecidos, num processo de engenharia reversa, onde busca-se descobrir os princípios tecnológicos e o funcionamento do robô através da análise de sua estrutura, função e operação.

Neste tipo de utilização é preciso ter conhecimento de MatLab e linguagens básicas de programação para reprogramar o sistema operacional do robô por meio de um kit de desenvolvimento, chamado SDK (System Kit Development) do ROS. O pesquisador repassa os algoritmos ao sistema através do MatLab para validar posições e movimentação para diferentes fins de programação. O processo é recursivo, onde algoritmos são escritos, simulados para que, sejam testados. O aparato é composto por três computadores, a caixa mecânica do MH08, seu teach pendant (controle manual) e uma sirene.

As dificuldades encontradas giram em torno da integração de diferentes dispositivos ao sistema. Ao gerar novos comandos de funcionamento para o robô, outros aspectos precisam ser recriados para que se controle seu funcionamento e para isso são acoplados ao sistema outros computadores para visualizar esses parâmetros. Assim se cria a necessidade de interagir com diferentes monitores (interfaces auxiliares) e controles remotos.

Enquanto supervisores destes robôs, é preciso considerar o tempo entre o comando de uma ação e sua execução real, já que existe um retardo natural ou lag entre a o momento da intervenção e o tempo que o sistema efetivamente executa a ação. Por isso, este tipo de operação exige que o operador anteveja situações e esteja sempre atento, tendo conhecimento do funcionamento mecânico e de programação em software. Outro aspecto do sistema é o fato de que erros são mostrados ao usuário de forma genérica, sem que se saiba exatamente sua origem. Ademais, dependendo da movimentação ou posição objetivada pelo algoritmo a documentação disponibilizada em Opensource pode não conhecer o erro. 

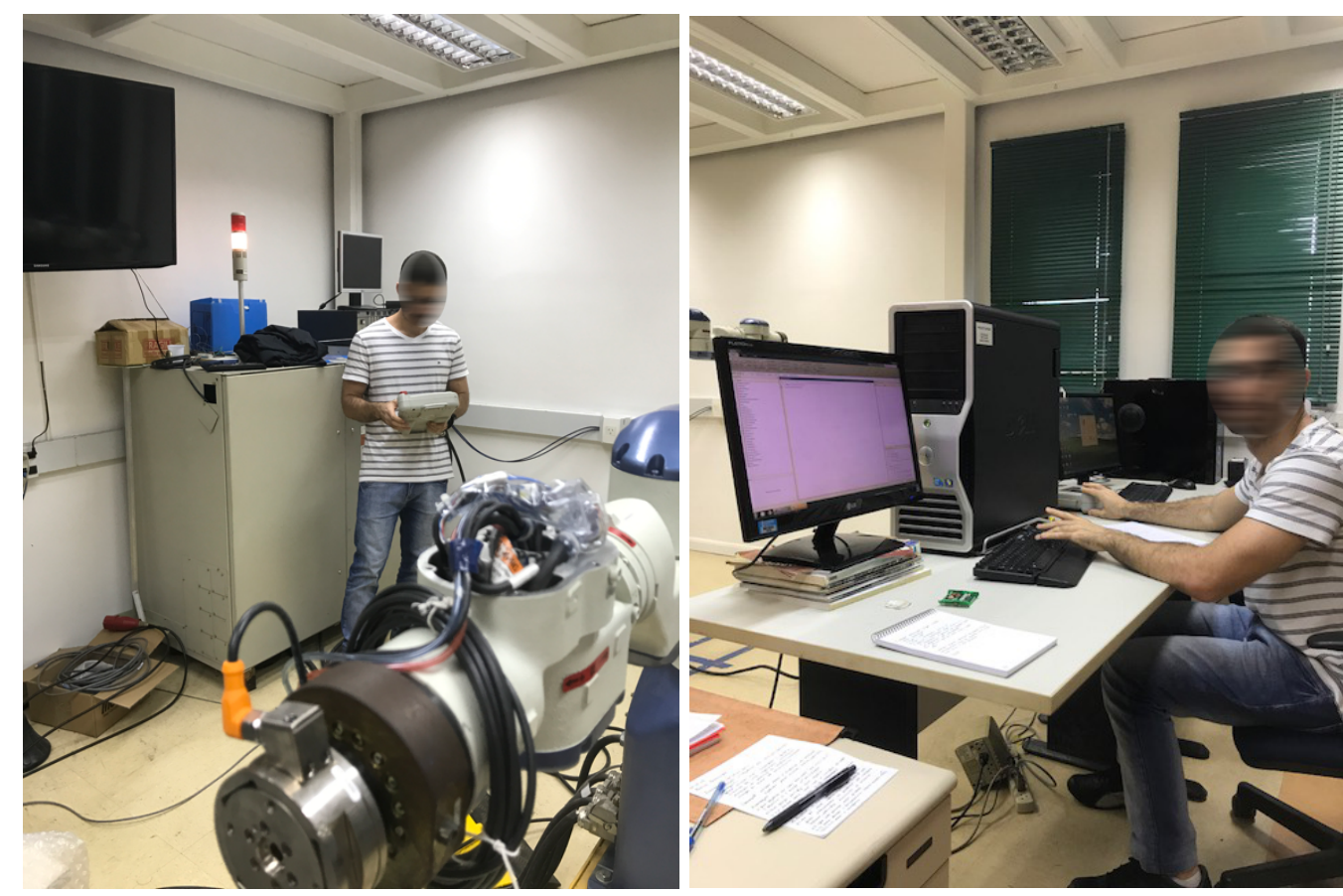

Figura 7.1 - Um dos entrevistados, e usuário do robô Dóris, em ambiente do laboratório LEAD da UFRJ.

\section{Robô Móvel Roomba/Usuário 02}

O Roomba é um robô aspirador móvel. Sua utilização na pesquisa do laboratório LEAD-UFRJ é como uma base móvel, com o objetivo transportar outros dispositivos como sensores e câmeras (Figura 7.2). Seu sistema operacional é reprogramável por meio de ROS, e ele possui um SDK, específico para desenvolver estratégias novas de funcionamento.

Para utilizá-lo é preciso conectá-lo a um computador que, através de uma SDK chamado TWIST, permite que manipular algoritmos em MatLab, validar posições e acessar as informações dos sensores que carrega. Seu modelo de trabalho é recursivo, onde se escreve o algoritmo, testa sua eficácia em simulação para posteriormente executar a tarefa.

Neste contexto, o robô Roomba apresenta uma autonomia previamente programada, limitando sua locomoção. A interação com o robô apresenta problemas relacionados ao feedback visual de funcionamento do sistema. Os dados capturados pelos sensores de proximidade determinam sua movimentação, sendo visualizados sob a forma de números e necessitando interpretação por parte do operador para tomada de decisão. Outro problema é o gerenciamento de bateria, que passa a ser utilizada para suprir uma necessidade operacional maior do que a 
pré-estabelecida na atividade original de aspiração. A visualização de uma interface basicamente em terminal também demonstra a necessidade do nível de conhecimento por parte do operador e a dificuldade natural de interpretar dados de forma constante.
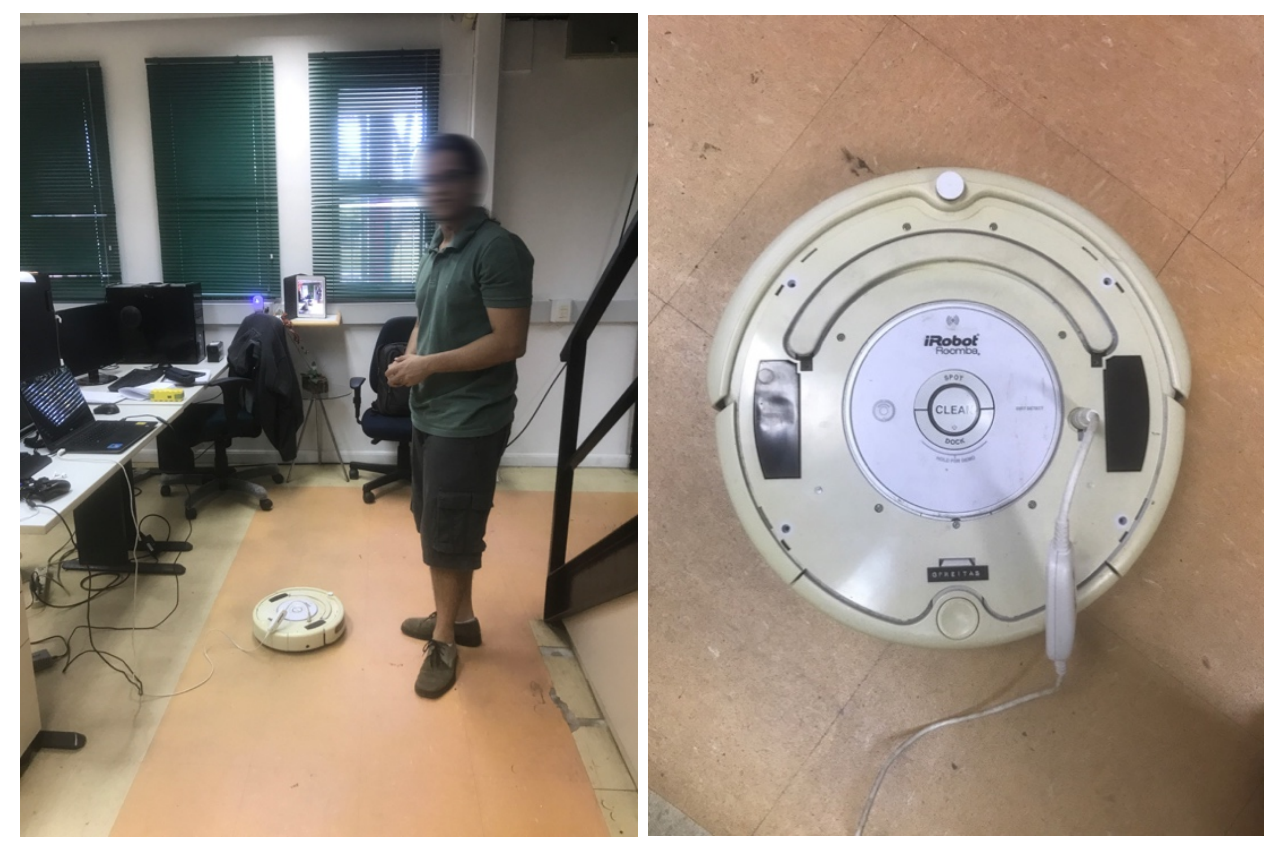

Figura 7.2 - Usuário do robô Roomba no ambiente do laboratório LEAD da UFRJ.

\section{Garra robótica/Usuário 02}

A garra robótica é utilizada para a manipulação de objetos. No contexto de pesquisa do laboratório LEAD da UFRJ é utilizada em conjunto com o sensor Kinect para reconhecer cores e estimular movimentação a partir dos canais RGB do Kinect. Sua utilização então busca validar algoritmos criados para movimentação das juntas uma vez que identifica os objetos a serem manipulados. Dentro da perspectiva da engenharia reversa foi criada uma biblioteca customizada com comandos de ROS para que estes movimentos pudessem ser reprogramados. O robô é utilizado para demonstrações de estruturas robóticas, mostrando o tipo de atividade que se estabelece ao reprogramar sistemas autônomos na captação de estudantes e jovens pesquisadores para iniciação científica.

O SDK utilizado para sua reprogramação oferece pouca documentação e visualização numérica de dados. Seu gerenciamento em Terminal ilustra o intuito simples de integrar o sensor Kinect para permitir que a identificação de objetos nas cores verde, vermelho e azul (Red, Green and Blue, RGB) projetadas em um 
monitor. Outros aspectos da interação apresentam problemas como; (1) o não estabelecimento de limite nas juntas acarreta em mal funcionamento ou travamento do sistema, (2) diferença entre o tempo de compilação do Kinect e o tempo de processamento da imagem, (3) difícil identificação do tipo de problema, (4) necessidade de criar protocolos de comunicação, (5) resolução de sensores não identifica o que está sendo manipulado, não combinando com a programação e prejudicando percepção do objeto por parte do usuário, (6) resolução de problema através de averiguação de funcionamento físico, teste de partes.
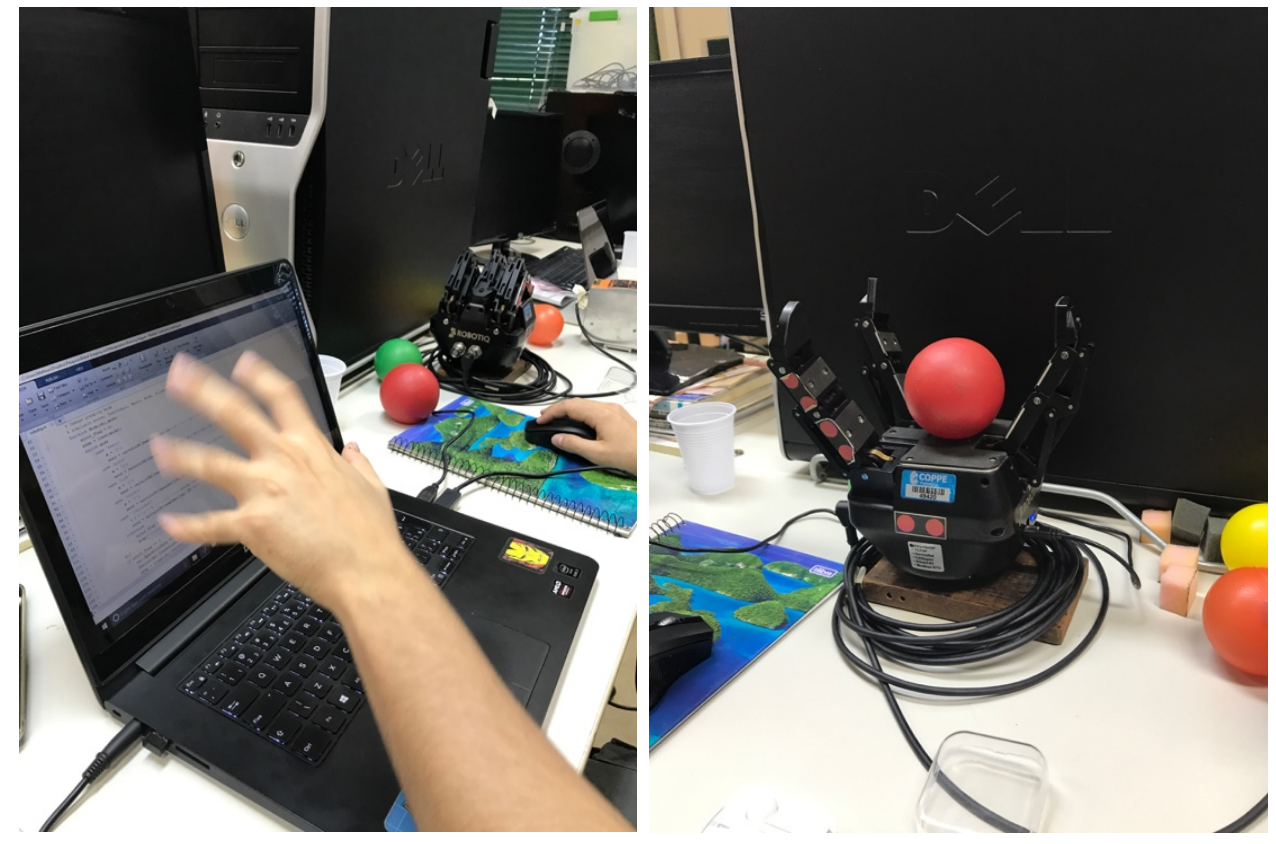

Figura 7.3 - Usuário Garra robótica no ambiente do laboratório LEAD da UFRJ.

\section{Robô Móvel sob trilhos Dóris/Usuário 03}

O robô DORIS é um robô móvel que se locomove sobre trilhos com o objetivo de realizar inspeções em plataformas de petróleo. Seu aparato robótico é composto por câmera para filmagem de ambiente, sensores capazes de identificar anomalias sonoras, de temperatura e de pressão. O robô está em fase de desenvolvimento e o protótipo atual tem como objetivo identificar o percurso proposto e testar sua locomoção de acordo, gravando o trajeto executado na inspeção, e testando quaisquer anomalias do ambiente.

Para operá-lo, é preciso um computador para se conectar ao robô no sistema operacional ROS via WI-FI, sendo a operação executada através de uma RUI estruturada no IDE Qt Creator, que integra a interface gráfica de todos os sensores 
utilizados. $\mathrm{O}$ acesso ao código é feito somente quando a interface falha. $\mathrm{O}$ modelo de trabalho se baseia em (a) ligar computadores; (b) acionar eletrônica; (c) ativar motores; (d) acessar interface de usuário através do ROS; (e) testar funcionamento de partes com feedback visual. O funcionamento de sensores é acusado por luzes de LED vermelhas ou verdes sendo cada um deles visualizado em uma janela. Tal RUI também visualiza inclinações e alternâncias de som no ambiente. Para executar uma tarefa, o operador precisa programar sua inspeção com horário, duração e número de execuções. Esta ronda pode ser editada ou agendada de acordo com a necessidade de inspeção, e durante seu processo existe supervisão por parte do operador.

As falhas de interação do Dóris são relacionadas com a carga de trabalho em virtude das ações repetitivas para ativar seu funcionamento, assim como as múltiplas janelas que apresentam informação de sensores, exigindo atenção em pontos diferentes que não podem ser visualizados simultaneamente. $O$ monitoramento da inspeção, com o robô em constante movimento, pode prejudicar a percepção do operador tanto pela qualidade quanto pelo ponto de vista da câmera. Ademais, a necessidade de foco constante na tela torna o operador propenso à distração em virtude de outras demandas de atenção e da troca de janelas para obtenção de informação. O debbug de problemas que não podem ser resolvidos na interface é feito através de terminal.

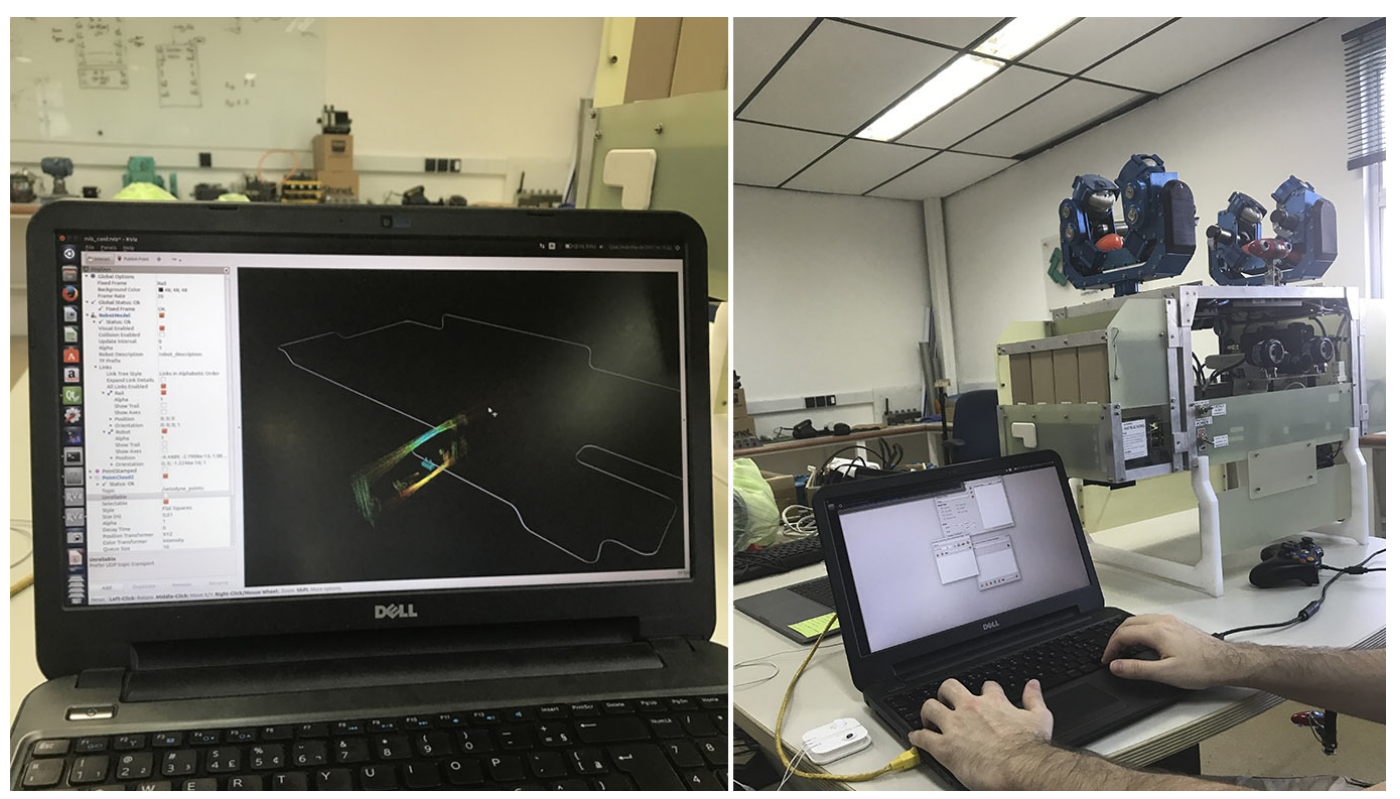

Figura 7.4 - RUI do robô Dóris durante a entrevista no ambiente do laboratório LEAD da UFRJ. 


\section{Robô submarino Luma / Usuário 04}

O robô LUMA é um robô submarino que tem por objetivo fazer levantamentos de biodiversidade marinha na Antártica e foi desenvolvido no laboratório LEAD da UFRJ. Seus componentes envolvem dois tipos de câmeras diferentes com maior e menor capacidade de memória, além de uma bússola, um barômetro (pressão), um termômetro, GPS, sonar de varredura e propulsores. O protótipo atual do robô tem como tarefa executar um transecto, que significa um percurso filmado do fundo do mar compilado em um trecho que compõe um mapa da distância percorrida na missão.

Para que operá-lo é preciso um ou mais computadores conectados a WI-FI que fazem interface com ROS e ativam o uso do robô. O sistema pode ser utilizado simultaneamente, por um usuário que controla o robô de forma direta (controle manual) ou indireta (monitoramento e supervisão), e também por especialistas que acompanham a operação em tempo real de outro computador, para apurar de informação. A operação é feita por meio de uma RUI estruturada no Qt Creator, que integra a interface gráfica de todos os sensores utilizados.

As câmeras do LUMA geram arquivos pesados para processamento. Sua interface possui muitos dados a serem analisados e por vezes divide em janelas informações importantes sem permitir que cominações necessárias de sensores sejam visualizadas simultaneamente. O sistema pode superaquecer mesmo considerando a baixa temperatura da água, e não é possível fazer análise de informações em tempo real.
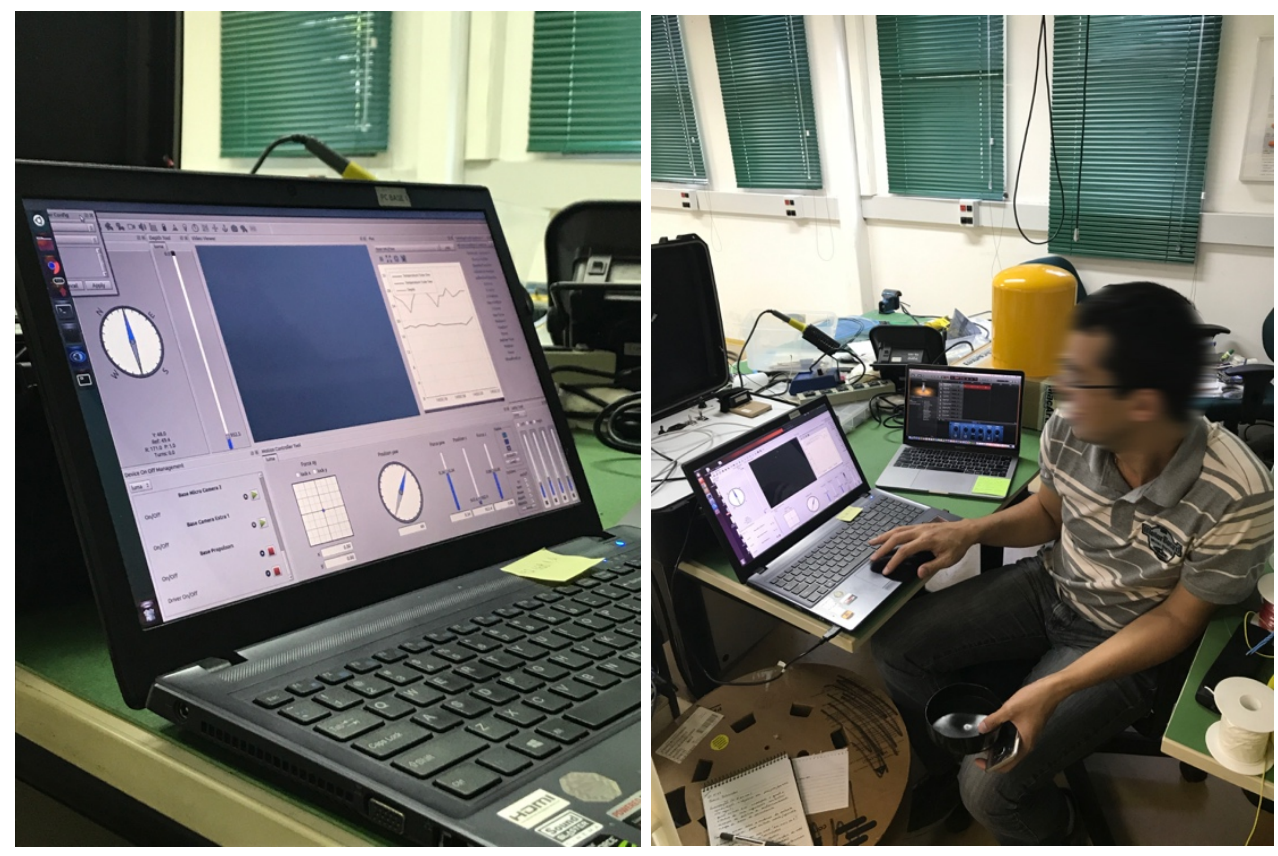
Figura 7.5 - RUI do robô Luma durante a entrevista no ambiente do laboratório LEAD da UFRJ.

\section{Drone DJI / Usuário 05}

O robô Drone DJI é um robô voador que faz fotos e trajetos filmados em seus voos. Seu controle é feito sob diferentes modos manuais e autônomos. O DJI é um robô de serviço em larga utilização, não sendo um protótipo e sendo operado 100\% fisicamente e através de sua interface de usuário. Os componentes são Drone com bateria, hélices removíveis, controle remoto e um dispositivo móvel para visualização da interface. Sua RUI funciona como um aplicativo, destinado a usuários finais comuns, já aborda diversos problemas clássicos encontrados em protótipos relacionados a comunicação,feedback visual e predição de perigos entre outros.

Para controlá-lo, em tese, não é preciso o aplicativo. O Drone executa trajetos ou missões pré-estabelecidos com autonomia. Desta forma, se o usuário optar por fazê-lo manualmente o controle remoto combinado com o aplicativo, é utilizado para seu controle. O robô possui diferentes modos de autonomia, tanto um modo manual quanto modos autônomos. Os modos autônomos podem ser guiados por meio de GPS do celular ou podem seguir objetos utilizando sua referência visual capturada previamente por sensores. O robô funciona com a utilização recorrente de diversos sensores, como que por excesso de informação ou cruzamento de mesma informação sob perspectivas diferentes (sensor de proximidade para determinar onde está o chão e também de altitude por exemplo). Mesmo que operados de forma manual, a inteligência artificial do robô permite tomada de decisão em uma frequência muito mais alta e, consequentemente mais rápida do que o entendimento do usuário. Ao observar seu funcionamento, foi possível concluir que, para o usuário final, só é possível controlá-lo com destreza em função dessa inteligência artificial, que dá liberdade para o controle manual, porém conserva o controle do sistema com recursos variados diante de problemas de interação. 

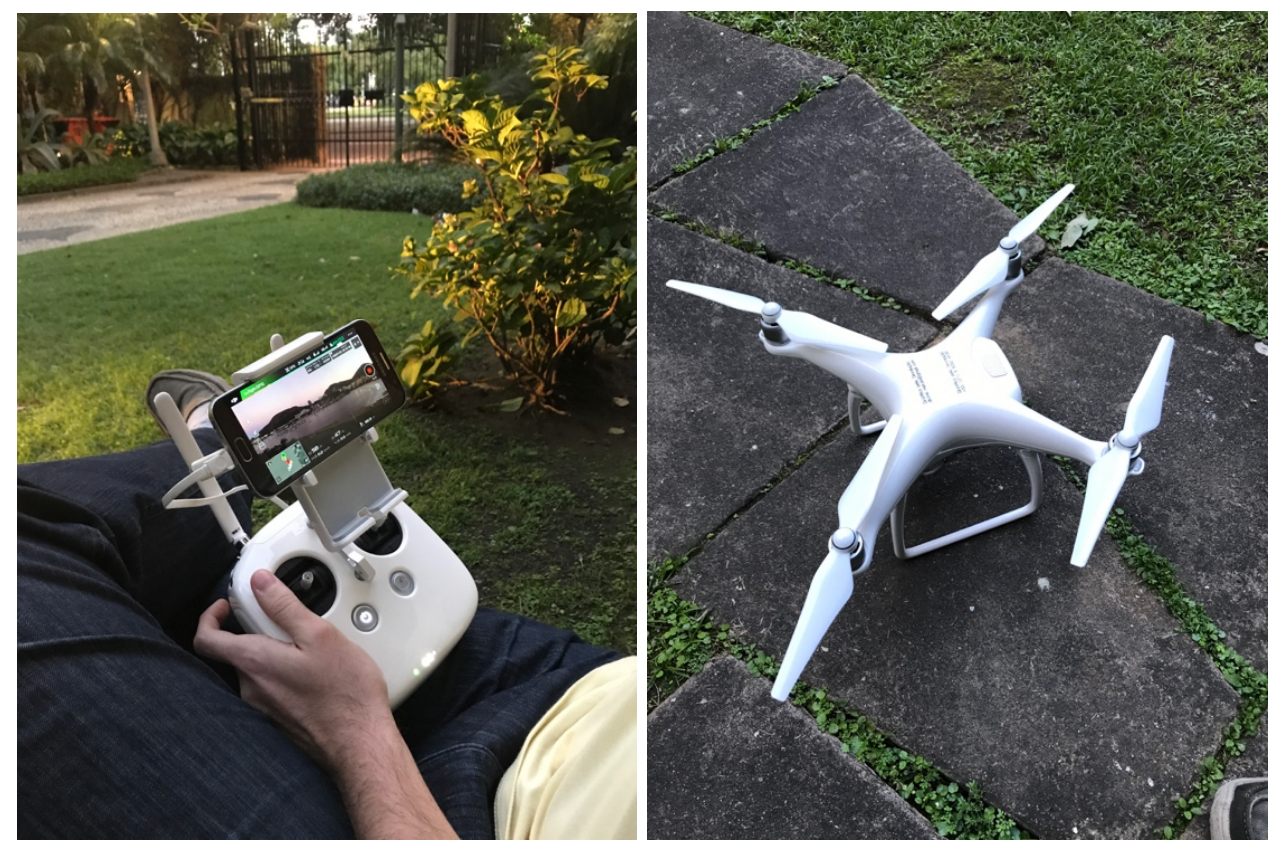

Figura 7.6 - RUI do DJI durante a entrevista em ambiente externo.

\subsection{2.}

\section{Falhas na interação com robôs}

No contexto da pesquisa ainda é muito comum encontrar problemas de interação nas interfaces de usuários observadas em virtude do ambiente de desenvolvimento. Projetos como os do robô Dóris e o do robô Luma já existem há alguns anos e a cada nova fase busca-se o aperfeiçoamento dos componentes de sistema e RUIs. Já robôs com DJI permitem a observação em um espectro oposto, onde suas RUIs além de voltadas para usuários finais - abordando problemas clássicos de interação da IHR - contam com inteligência artificial do sistema que é capaz de lidar com inúmeros problemas antes que se tornem visíveis para o usuário.

Nas entrevistas contextuais, foram confirmadas apontamentos de autores como Harrys e Beringer (2007) apud Gikkas (2013) e HSE (2003) sobre possíveis causas de erros ou falhas em um sistema automatizado tais como: a falta de treino dos operadores para utilizar o sistema; a falta de um modelo conceitual que auxilie o entendimento das operações realizadas automaticamente; o mau funcionamento devido a limitações de sensores e interpretações imprecisas que acarretam em um suporte não satisfatório para o usuário.

Ao analisar os dados relativos a problemas de interação, foi possível perceber que, de fato as falhas descobertas durantes as entrevistas em muito se relacionam com as falhas mais comuns apontadas na literatura. Problemas relacionados a: (a) 
análise de múltiplas telas, (b) processamento de informação oriundo de diversos sensores, necessitando uma síntese por parte do operador, (3) feedback com relação ao status do sistema (hardware e/ou software) e tempo de respostas entre comando e ação do robô. No quadro abaixo (6.4), as falhas que serão ser utilizadas com as variáveis dependentes no teste de usabilidade. No quadro 7.1 foram listadas as falhas de interação observadas.

Quadro 7.1 - Problemas de interação recorrentes observadas durante as entrevistas.

\title{
Problemas observados nas Entrevistas Contextuais
}

\author{
Telas diferentes para serem analisadas na execução de tarefas. \\ Informação oriunda de múltiplos sensores ou fontes dificulta a tomada de decisão. \\ Feedback de status de sistema tanto para hardware, como de software escasso ou impreciso. \\ Falta de priorização em alertas gera confusão de onde atuar primeiro mediante a um problema \\ Tempo entre comando e resposta do robô. \\ Aspetos de clareza na percepção visual da operação e de seus elementos. \\ Difícil manipulação do mundo do robô pela interface.
}

Posteriormente, as falhas listadas foram relacionadas com a modelagem de erros com automação feita por Gonçalves e Quaresma (2015) e com as diretrizes de design propostas na literatura da IHR. Desta forma, buscou-se enquadrar os problemas de interação observados ao contexto de uso dos robôs avaliados na pesquisa (Quadro 7.2).

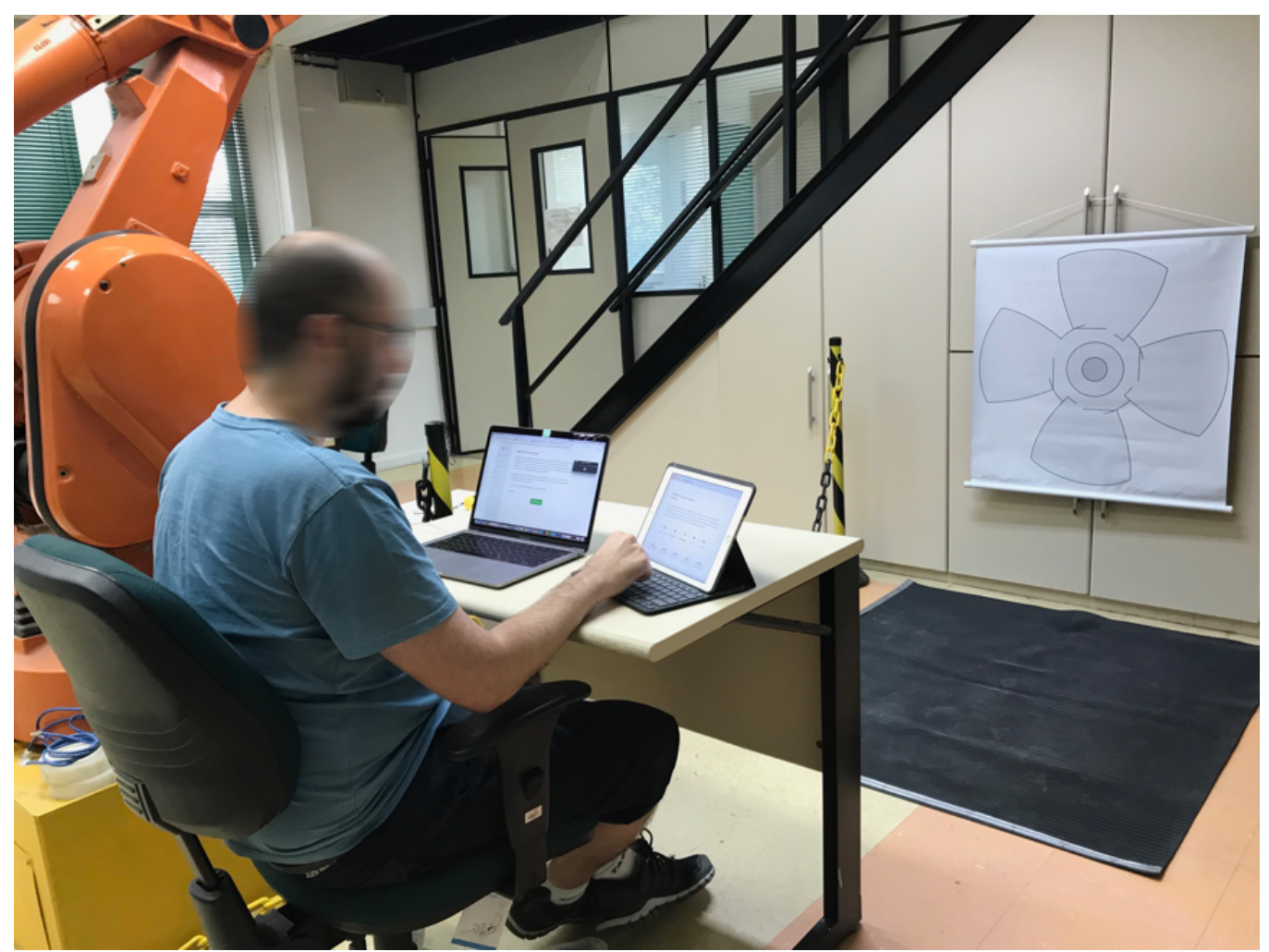


Figura 7.7 - Ambiente de teste com representação física da operação a frente do participante.

Quadro 7.2 - Relação de falhas relatadas nas entrevistas com modelagem de erros e diretrizes de design. 


\begin{tabular}{|c|c|c|}
\hline $\begin{array}{l}\text { Problemas observados } \\
\text { nas entrevistas }\end{array}$ & $\begin{array}{l}\text { Tipos de erros com automação } \\
\text { Gonçalves e Quaresma (2015) }\end{array}$ & Diretrizes de Design \\
\hline $\begin{array}{l}\text { Telas diferentes para } \\
\text { análise na execução de } \\
\text { tarefas. }\end{array}$ & $\begin{array}{l}\text { Out of the Loop: Este tipo de erro acontece quando a } \\
\text { vigilância do usuário sob determinado aspecto está em } \\
\text { níveis baixos ou inexistentes, não notando o } \\
\text { funcionamento do sistema, e assim tornando-se incapaz } \\
\text { de agir com prontidâo, caso necessário, durante uma } \\
\text { situação atípica. Este tipo de erro ocorre no processo de } \\
\text { observação por parte do usuário, comprometendo } \\
\text { diretamente questões ligadas à consciência da situação } \\
\text { e carga de trabalho. }\end{array}$ & $\begin{array}{l}\text { Aumentar Informação sobre ambiente do } \\
\text { Robô } \\
\text { Fornecer mais informações espaciais } \\
\text { sobre o robô no ambiente operacional, } \\
\text { tornando operadores mais conscientes } \\
\text { dos arredores imediatos dos robôs. }\end{array}$ \\
\hline $\begin{array}{l}\text { Informação vinda de } \\
\text { múltiplas fontes } \\
\text { dificulta a tomada de } \\
\text { decisão. }\end{array}$ & $\begin{array}{l}\text { Incapacidade operacional: Tipo de erro que ocorre } \\
\text { quando, apesar da leitura correta do cenário e tomada } \\
\text { de decisão precisa, o operador é incapaz de realizar as } \\
\text { ações planejadas em tempo hábil, seja pela complexi- } \\
\text { dade da tarefa ou pelo curto espaço de tempo. Este tipo } \\
\text { de erro ocorre no processo de ação do usuário, } \\
\text { interferindo em questões relacionadas exclusivamente à } \\
\text { carga de trabalho. }\end{array}$ & $\begin{array}{l}\text { Projetar apenas a informação necessária, } \\
\text { evitando sínteses mentais. } \\
\text { A interface deve ser projetada para } \\
\text { transmitir informações "apenas o } \\
\text { suficiente": o suficiente para que o } \\
\text { humano possa determinar se a } \\
\text { intervenção é necessária, e não tanto que } \\
\text { cause sobrecarga. }\end{array}$ \\
\hline $\begin{array}{l}\text { Feedback de status de } \\
\text { sistema tanto para } \\
\text { hardware, como de } \\
\text { software escasso ou } \\
\text { impreciso }\end{array}$ & $\begin{array}{l}\text { Vacilo de atenção: Tipo de erro está diretamente ligado } \\
\text { a aspectos de falibilidade humana -fadiga, distração e } \\
\text { afins. Ocorre quando, mesmo em estado de alerta, o } \\
\text { operador se mostra inapto a assimilar todas as } \\
\text { variáveis relevantes durante o funcionamento do } \\
\text { sistema. Este tipo de erro acontece no processo de } \\
\text { observação do usuário e interfere em questões } \\
\text { diretamente relacionadas à carga de trabalho. } \\
\text { Erro de máquina: Este tipo de erro que ocorre quando, } \\
\text { apesar de uma interação perfeita entre humano e o } \\
\text { sistema automatizado, ocorre um mal funcionamento da } \\
\text { máquina, gerando resultados indesejados e imprevisí- } \\
\text { veis. Este tipo de erro acontece no decorrer do processo } \\
\text { de execução da ação por parte da máquina, e não } \\
\text { interfere diretamente em nenhuma questão relacionada } \\
\text { ao usuário, uma vez que este tipo de falha não pode ser } \\
\text { evitado pelo mesmo durante a operação. }\end{array}$ & $\begin{array}{l}\text { Visibilidade do Status do Sistema \& } \\
\text { Feedback Visual } \\
\text { O sistema deve sempre manter os } \\
\text { usuários informados sobre o que está } \\
\text { acontecendo, através de feedback } \\
\text { adequado dentro de um prazo razoável. O } \\
\text { sistema deve transmitir seu modelo ao } \\
\text { usuário para que o usuário tenha uma } \\
\text { compreensão completa da consciência } \\
\text { situacional do sistema. }\end{array}$ \\
\hline $\begin{array}{l}\text { Falta de priorizaçāo em } \\
\text { alertas gera confusão de } \\
\text { onde atuar primeiro } \\
\text { mediante a um } \\
\text { problema. }\end{array}$ & $\begin{array}{l}\text { Out of the Loop: Este tipo de erro acontece quando a } \\
\text { vigilância do usuário sob determinado aspecto está em } \\
\text { niveis baixos ou inexistentes, não notando o } \\
\text { funcionamento do sistema, e assim tornando-se incapaz } \\
\text { de agir com prontidão, caso necessário, durante uma } \\
\text { situação atípica. Este tipo de erro ocorre no processo de } \\
\text { observação por parte do usuário, comprometendo } \\
\text { diretamente questões ligadas à consciência da situação } \\
\text { e carga de trabalho. }\end{array}$ & $\begin{array}{l}\text { Compatibilidade entre Sistema e } \\
\text { Mundo Real } \\
\text { O mundo do robô deve ser projetado } \\
\text { de forma similar ao entendimento do } \\
\text { ser humano, seguindo convenções do } \\
\text { mundo real, fazendo com que a } \\
\text { informação apareça de forma natural } \\
\text { e lógica na interface com usuário. }\end{array}$ \\
\hline $\begin{array}{l}\text { Tempo entre comando e } \\
\text { resposta do robô }\end{array}$ & $\begin{array}{l}\text { Vacilo de atenção: Tipo de erro está diretamente ligado } \\
\text { a aspectos de falibilidade humana - fadiga, distração e } \\
\text { afins. Ocorre quando, mesmo em estado de alerta, o } \\
\text { operador se mostra inapto a assimilar todas as } \\
\text { variáveis relevantes durante o funcionamento do } \\
\text { sistema. Este tipo de erro acontece no processo de } \\
\text { observação do usuário e interfere em questões } \\
\text { diretamente relacionadas à carga de trabalho. } \\
\text { Erro de máquina: Este tipo de erro que ocorre quando, } \\
\text { apesar de uma interação perfeita entre humano e o } \\
\text { sistema automatizado, ocorre um mal funcionamento da } \\
\text { máquina, gerando resultados indesejados e imprevisí- } \\
\text { veis. Este tipo de erro acontece no decorrer do processo } \\
\text { de execução da ação por parte da máquina, e não } \\
\text { interfere diretamente em nenhuma questão relacionada } \\
\text { ao usuário, uma vez que este tipo de falha não pode ser } \\
\text { evitado pelo mesmo durante a operação. }\end{array}$ & $\begin{array}{l}\text { Visibilidade do Status do Sistema \& } \\
\text { Feedback Visual } \\
\text { O sistema deve sempre manter os } \\
\text { usuários informados sobre o que está } \\
\text { acontecendo, através de feedback } \\
\text { adequado dentro de um prazo razoável. O } \\
\text { sistema deve transmitir seu modelo ao } \\
\text { usuário para que o usuário tenha uma } \\
\text { compreensão completa da consciência } \\
\text { situacional do sistema. }\end{array}$ \\
\hline $\begin{array}{l}\text { Aspetos de clareza na } \\
\text { visualização da operação e } \\
\text { elementos. }\end{array}$ & $\begin{array}{l}\text { Imprevisibilidade: Este tipo de erro acontece quando o } \\
\text { operador se mostra incapaz de definir o modelo de } \\
\text { funcionamento da máquina, fazendo com que o mesmo } \\
\text { não consiga antever as reações do sistema diante de } \\
\text { determinada situação eminente. Este tipo de erro ocorre } \\
\text { no processo de orientação em conjunto com a tomada } \\
\text { de decisão - recorrente em operadores com pouca } \\
\text { experiência com o sistema operado. Interfere } \\
\text { diretamente em questões relacionadas à consciência da } \\
\text { situação. }\end{array}$ & $\begin{array}{l}\text { Ponto de Vista Compatível } \\
\text { A projeção de mundo no sistema deve ser } \\
\text { visualizada sob um ponto de vista } \\
\text { compatível para o entendimento da } \\
\text { tarefa, permitindo que o operador possa } \\
\text { determinar se a intervenção é necessária } \\
\text { ou não. }\end{array}$ \\
\hline
\end{tabular}




\section{2.}

\section{Análise dos Resultados dos testes de usabilidade}

As sessões do Teste de Usabilidade sucederam no período entre os meses de novembro e dezembro de 2017, no Laboratório de Ergodesign e Usabilidade de Interfaces (LEUI) da PUC-Rio, e também no Laboratório de Controle e Automação, Engenharia de Aplicação e Desenvolvimento (LEAD) da Universidade Federal do Rio de Janeiro. O critério principal de escolha para seleção dos participantes dos testes de usabilidade foi possuir experiência de interação com sistemas robóticos. Por sistemas robóticos entende-se robôs de serviço, como robôs móveis, submarinos, drones e correlatos. Os participantes possuíam idades entre 25 e 35 anos de idade, e foram divididos de forma aleatória em dois grupos: o grupo do Teste A (sem diretrizes, participantes de sigla P01 à P06) e do Teste B (com diretrizes, participantes de sigla $\mathrm{P} 07$ à P12), todos eles com familiaridade com sistemas robóticos de alguma espécie.

\section{Completude de Tarefas}

Mediante dois tipos de interface, procurou-se medir o desempenho dos usuários na realização de cinco tarefas. Em ambas as interfaces, houve $100 \%$ de completude entre os participantes. No entanto, era possível chegar ao final do teste mesmo que se completassem as tarefas com valores incorretos. Por isso, como critério de análise de completude das tarefas, considerou-se $100 \%$ para a completude bem-sucedida, sendo decrescida a porcentagem proporcional ao número de inputs de cada tarefa. Como exemplo, tem-se a Tarefa 4, que continha quatro inputs: proporcionalmente a cada erro de input seriam decrescidos $25 \%$, contabilizados apenas no final, quando o participante anunciava ter completado a tarefa. Houve uma diferença substancial na ocorrência de erros entre participantes da Interface A (sem diretrizes) e da Interface B (com diretrizes), tendo o grupo do Teste A apresentado um maior número de erros (18 de input e 6 de navegação) do que o grupo do Teste B ( 5 de input e 2 de navegação). Consequentemente, a incidência maior de erros de input no Teste A trouxe um desempenho pior na completude das tarefas dos participantes deste grupo. Em um panorama geral, o 
teste com diretrizes se mostrou menos passível de input errados, possibilitando aos participantes menos chances de erro.

Tabela 7.1 - Incidência e tipos de erros.

\begin{tabular}{|c|c|c|c|c|c|c|c|c|c|c|c|c|}
\hline & \multicolumn{6}{|c|}{ TESTEA } & \multicolumn{6}{|c|}{ TESTE B } \\
\hline PARTICIPANTE & P01 & $\mathrm{P} 02$ & $\mathrm{P} 03$ & P04 & P05 & P06 & P07 & P08 & P09 & P10 & P11 & P12 \\
\hline TAREFA 5 & & & & & & & & 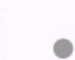 & & & & $\bullet$ \\
\hline TAREFA 4 & - & $\stackrel{0}{\bullet}$ & & 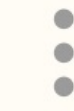 & 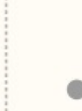 & $\bullet$ & 0 & 0 & & & & \\
\hline TAREFA 3 & $\bullet$ & $\circ \bullet$ & & $\circ \bullet$ & 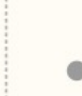 & $\bullet$ & & & $\bullet$ & - & & \\
\hline TAREFA 2 & O & O & & o & 0 & & & & & O & 0 & \\
\hline TAREFA 1 & & & & & & • & & & & & & \\
\hline & • & $\begin{array}{l}\text { aro de in } \\
\text { aro de }\end{array}$ & $\begin{array}{l}\text { ut } \\
\text { vegaçã }\end{array}$ & & $\square$ & $\begin{array}{l}\text { ESTE A } \\
\text { ESTE B }\end{array}$ & & & & & & \\
\hline
\end{tabular}

\section{Tempo de Tarefas}

De uma forma geral, os intervalos de tempo obedeceram a um padrão parecido em ambos os testes, uma vez que seus valores de maior e menor tempo eram similares. As Tarefas 1, 3 e 4 foram realizadas em menor média de tempo pelos participantes do Teste B (interface com diretrizes). Nestas tarefas, os participantes do Teste B também obtiveram um melhor desempenho, errando menos tanto em termos de input, quanto em termos de navegação. Já os participantes do Teste A (interface sem diretrizes), foram mais velozes nas Tarefas 2 e 5 . No entanto seu desempenho foi melhor apenas na tarefa 5, enquanto na Tarefa 2, apesar do menor tempo (média 3 segundos abaixo do Teste B), os participantes obtiveram um maior número de erros de navegação.

A seguir, o Gráfico 7.3 relaciona o desempenho dos participantes dos Testes $\mathrm{A}$ e $\mathrm{B}$, em cada tarefa, no que se refere à incidência de erros e a média de tempo em segundos. $\mathrm{O}$ gráfico, permite observar, que em referência à contagem de tempo e à velocidade com que tarefas foram executadas, foi estabelecida uma relação com uma melhor completude e menor número de erros entre os testes nos participantes 
do Teste $\mathrm{B}$, já que estes foram mais eficientes e eficazes nas três tarefas em que foram mais velozes.

Tabela 7.2 - Tabela da Tarefa 1.

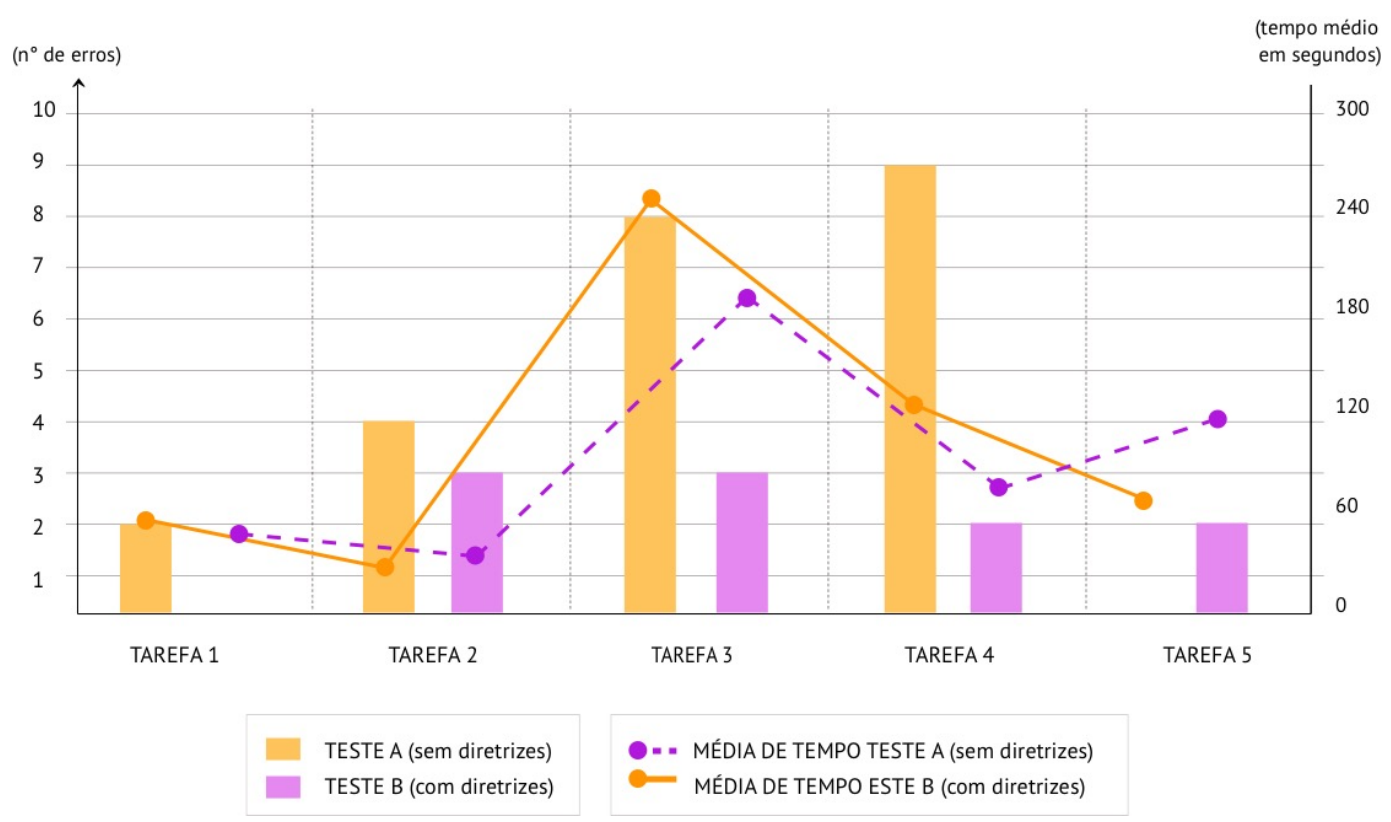

\section{Tarefa 1 - Projetar Informação apenas necessária}

A Tarefa 1, denominada parâmetros do ambiente, buscou medir a usabilidade da diretriz de IHR relativa a 'projetar apenas a informação necessária, evitando sínteses mentais'. Sua interface consistia na apresentação da informação de sensores de duas formas distintas: no Teste A (interface sem diretriz) os usuários precisavam olhar parâmetros na tela e calcular mentalmente se os valores obedeciam ao sistema, enquanto no Teste B (interface com diretrizes) havia indicação de cor para cada estado possível dentro dos parâmetros apresentados.

A tarefa teve melhor desempenho na completude e tempo do Grupo B, com 100\% de completude de tarefas e uma média de tempo de 42 segundos. Já o grupo A teve média de tempo de 1:06, 24 segundos a mais que os participantes do Teste $\mathrm{B}$, além de obterem o único erro de input dentre os doze participantes dos testes. Desta forma, a diretriz se provou mais eficiente a medida que obteve melhor desempenho do que sua ausência.

\section{Tarefa 2 - Compatibilidade entre sistema e mundo real}

Na tarefa 2, denominada Seleção de Dano da Pá buscou medir a usabilidade da diretriz de IHR relativa a 'compatibilidade entre sistema e mundo real'. Assim, 
o mundo do robô a ser manipulado pelo usuário deve ser projetado de forma similar ao entendimento do ser humano, seguindo convenções do mundo real, e fazendo com que a informação apareça de forma natural e lógica na interface com usuário. Esta tarefa foi apresentada então com duas formas distintas de seleção de uma área com dano em uma pá, sendo nos dois testes, primeiro mostrada uma imagem da pá com dano, e em seguida sendo oferecida uma forma de seleção de área. No Teste A, a seleção era feita por meio de dropdown enquanto no Teste B a seleção era feita a partir de uma imagem de pá similar a imagem anterior com o dano.

Os participantes de ambos os testes tiveram 100\% de completude, apresentando apenas erros de navegação no Teste A e B, ao clicar excessivamente na interface com a imagem da pá e retomar para primeira tarefa. A média de tempo do Teste A foi de 39 segundos enquanto no Teste B obteve uma média de 42 segundos. Nesta tarefa, ficou mais difícil de estabelecer uma relação com a eficácia e eficiência da diretriz, uma vez que os números foram muito semelhantes, em relação ao tempo, assim como os erros no desempenho não afetaram sua completude. No entanto, a fim de comprovar a diretrizes é possível afirmar que os participantes do teste com diretriz erraram menos, e obtiveram um tempo quase similar aos participantes do Teste A.

Como pode ser observado na Tabela 6.2 (Tarefa 2), houve divergência de desempenho entre as tarefas.

Tabela 7.3 - Desempenho dos participantes na Tarefa 2.

\begin{tabular}{|c|c|c|c|c|c|c|}
\hline TESTE & PARTICIPANTES & COMPLETUDE & ERROS NAV. & ERROS INPUT & TEMPO & MEDIA \\
\hline \multirow{6}{*}{ A } & P01 & $100 \%$ & 1 & 0 & $00: 25 s$ & \multirow{6}{*}{$39 \mathrm{~s}$} \\
\hline & P02 & $100 \%$ & 1 & 0 & $00: 24 s$ & \\
\hline & P03 & $100 \%$ & 0 & 0 & $00: 41 \mathrm{~s}$ & \\
\hline & P04 & $100 \%$ & 1 & 0 & $00: 31 \mathrm{~s}$ & \\
\hline & P05 & $100 \%$ & 1 & 0 & $01: 25 s$ & \\
\hline & P06 & $100 \%$ & 0 & 0 & $00: 30 \mathrm{~s}$ & \\
\hline \multirow{6}{*}{ B } & P07 & $100 \%$ & 1 & 0 & $00: 28 \mathrm{~s}$ & \multirow{6}{*}{$42 \mathrm{~s}$} \\
\hline & P08 & $100 \%$ & 1 & 0 & $01: 01 \mathrm{~s}$ & \\
\hline & P09 & $100 \%$ & 0 & 0 & $00: 43 \mathrm{~s}$ & \\
\hline & P10 & $100 \%$ & 1 & 0 & $00: 29 s$ & \\
\hline & P11 & $100 \%$ & 1 & 0 & $01: 03 s$ & \\
\hline & P12 & $100 \%$ & 0 & 0 & $00: 30 \mathrm{~s}$ & \\
\hline
\end{tabular}


Na tarefa 3, denominada 'Posicionamento', buscou-se medir a usabilidade da diretriz de IHR relativa a 'aumentar Informação sobre ambiente do robô', uma vez que se busca fornecer mais informações sobre o ambiente operacional para tornar os operadores mais conscientes dos arredores imediatos dos robôs. Esta tarefa foi a que mais demorou para ser executada, sendo sua média de tempo no Testa A de 256 segundos e 219 minutos no Teste B. Este tempo maior para a execução já era esperado, uma vez que esta tarefa requeria aos participantes que interagissem com o ambiente externo. Dentre as 5 Tarefas, foi a que os dois grupos de usuários enfrentaram maior dificuldade, já que envolvia a organização do espaço real de acordo com o que estava representado na interface.

Em termos de comprovação da diretriz, essa tarefa obteve um desempenho significantemente melhor no Teste B (com interfaces), onde seus participantes erraram menos e forma mais velozes, comprovando assim que a diretriz auxiliou em uma melhor usabilidade. Vale ressaltar que esta tarefa foi de grande importância para a o Robô EMMA, que possui fluxo de trabalho onde usuários interagem tanto com o mundo real no ambiente externo da operação, quanto com a interface de usuário remota.

\section{Tarefa 4 - Visibilidade do status do sistema \& feedback visual}

$\mathrm{Na}$ tarefa 4, denominada 'calibração' buscou-se medir a usabilidade da diretriz de IHR relativa à 'visibilidade do status do sistema \& feedback visual. De acordo com esta diretriz, o sistema deve sempre manter os usuários informados sobre o que está acontecendo, por meio de feedback adequado, dentro de um prazo razoável. O sistema deve transmitir seu modelo ao usuário para que o usuário tenha uma compreensão completa da consciência situacional do sistema.

Esta tarefa, apresentou diferença significativa em seu tempo de execução entre os Testes A e B. No teste A média foi de 156 segundos enquanto no Teste B esta média caiu mais de um minuto, resultando em 83 segundos. Esta diferença também ocorreu de forma significativa no desempenho de completude $(62,5 \%$ no Teste A contra $100 \%$ no Teste B) já que a incidência de erros de input por parte dos participantes do Teste A foi consideravelmente maior nos participantes do Teste B. Foi possível notar que os participantes do Teste A tiveram que eventualmente se referenciar ao mapa, acabando por cometer mais erros do que os participantes do 
Teste B que, por sua vez, obtiveram um feedback visual que permitia uma conclusão com menos esforço ao associar resultados com cor. Pôde-se então comprovar a maior usabilidade da diretriz.

\section{Tarefa 5 - Ponto de vista compatível com usuário}

$\mathrm{Na}$ tarefa 5, denominada 'simulação' buscou-se medir a usabilidade da diretriz de IHR relativa a 'ponto de vista compatível com usuário'. Ou seja, nesta tarefa procurou-se visualizar a tarefa sob ângulos diferentes, através de um vídeo com a simulação de execução do revestimento do robô EMMA, que resultava em um erro.

A tarefa 5 mostrou relativa semelhança em ambos os testes sendo a média do Teste A de 94 segundos e média do Teste B de 120 segundos. Em termos de completude esta foi a única tarefa que não obteve dados que comprovassem uma maior usabilidade da diretriz já que tempo de execução e quantidade de erros faram melhores no teste sem diretrizes. Neste caso a diretriz do ponto de vista não se provou.

\section{SUS}

O resultado do SUS corroborou, de certa forma, com o desempenho dos participantes, uma vez que, o grupo que obteve a menor quantidade e tipo de erros, além do melhor tempo de execução das tarefas, também foi o grupo que obteve a maior satisfação de acordo com o SUS. Ambos os grupos, do Teste A (sem diretrizes) e o grupo do Teste B (com diretrizes), obtiveram uma pontuação considerada boa. Os participantes do Teste A obtiveram média de 79,22, considerado ainda uma nota $\mathrm{C}$, porém no limiar de um B (a partir de 80). Já os participantes do Teste B (com diretrizes) apresentaram maior índice de satisfação, obtendo uma média de 83,75 , considerada B. A nota está muito próxima de 85 , considerado excelente. É válido ressaltar que, propositalmente, em nenhum dos testes os participantes foram informados sobre o sucesso ou as falhas nas suas tarefas antes da realização do SUS. A intenção disso foi a de permitir a contagem de erros sem interferências do sistema e não influenciar no nível de satisfação dos usuários. 


\section{8 \\ Conclusão}

Apesar de todo o avanço tecnológico e o recente e o aprendizado de máquinas, ainda somos nós, humanos, que determinamos os caminhos possíveis para o futuro do mercado de trabalho. Máquinas foram criadas para nos auxiliar no trabalho e não tomá-lo de nós. Não há como evitar que novas tecnologias, tal qual os robôs, se proliferem e gerem impacto em nossas vidas, no entanto, é necessário orquestrar que este impacto seja positivo, ao criar máquinas que sejam controladas e utilizadas com maior facilidade. A função primordial do robô é a de auxiliar os humanos em seu trabalho, ao reduzir esforços e executar tarefas complexas de forma precisa. Todavia, apesar destes benefícios, muitas preocupações pairam sobre o que acontece quando a tecnologia robótica falha, o que pode resultar em perdas econômicas, danos materiais, ferimentos ou até perdas de vida.

Nesta pesquisa, o estudo de interfaces gráficas do usuário em sistemas robóticos parte da ideia de que o comportamento humano oferece indicações para a diminuição de falhas e para interações mais eficientes. Desta forma, buscou elaborar formas de evitar essas falhas através da observação do comportamento de usuários na interação com robôs de serviço e da teoria sobre o trabalho coordenado com máquinas.

Para dissertar sobre a importância do design no desenvolvimento de robôs mais acessíveis, foi imprescindível não só entender a teoria dos modelos com automação e robôs, mas também, o papel do humano nesse trabalho. Para provar a hipótese de que, se interfaces específicas para sistemas robóticos forem concebidas considerando as especificidades dos modelos de interação humano-robô, as falhas operacionais serão reduzidas, foi preciso unir os dados relativos ao comportamento prático e teórico de usuários de máquinas robóticas, com as regras de design que se aplicam ao contexto de uso de RUI's. Assim, fez-se um apanhado na literatura sobre modelos de interação pertinentes, os tipos de erros com automação relacionados a robôs e as diretrizes de design existentes que se enquadram nestes modelos. Os 
dados coletados em entrevistas contextuais e na revisão bibliográfica apontaram às falhas recorrentes na interação.

O objetivo das entrevistas foi descobrir sobre as funções dos robôs, o que é preciso para ativá-los, seus modelos de trabalho e problemas de interação. O que pôde ser observado é que o trabalho com robôs que integram diferentes sistemas e ou dispositivos, muitas vezes não consegue concentrar a informação em uma interface de usuário apenas. Aqui usuários são especialistas, ou seja, possuem um conhecimento técnico de programação e interagem com mais de um programa para ativar o sistema ou passar comandos aos robôs, como no caso do Motoman MH8. É verdade que em algum desses projetos que vêm sendo aprimorados com o tempo, como robô Dóris por exemplo, possuem RUIs mais completas, onde é possível ativar e utilizar o robô em um sistema integrado. No entanto, a questão do feedback do sistema relativo a falhas continua a ser uma questão comum para todos os robôs observados: quando ocorre um problema, o robô não avisa o que é que está errado, cabe ao usuário, que tem conhecimento do funcionamento identificar tal falha e corrigi-la. Ademais, o chamado troubleshooting é feito sempre no backend, mesmo que a indicação do erro esteja presente de alguma forma na interface.

No referencial teórico desta dissertação (capítulo 3), definiu-se que a interação com robôs faz parte da interação com sistemas autônomos, sendo a HRI, uma subárea do HAI. Aqui, definiu-se o que são RUIs e o cenário de uso, além da correlação de diretrizes de design existentes na literatura pertinentes aos modelos de HRI e HAI. Ao compreender o nível de automação caracterizado pelo trabalho com robôs de serviço, foi possível relativizar o papel humano no contexto operacional a partir do paradigma do controle de supervisão. No outro espectro da pesquisa, regras de design existentes foram perfiladas ao comportamento humano observado na interação com robôs, com o propósito de demonstrar a importância para usabilidade e controle de sistemas autônomos. Para além do que foi observado nas entrevistas e organizado na literatura referente ao design de interfaces, os fatores humanos apontados na literatura relacionada a HAI e HRI, confiança, atenção situacional e carga de trabalho, permitiram um norte no entendimento do comportamento dos usuários, bem como a organização e classificação de diretrizes de design.

Como o método final e comprovador de hipótese, o teste de usabilidade buscou mensurar as diferenças entre uma abordagem considerando as 
especificidades da interação humano-robô e outra sem o uso dessas diretrizes. Os resultados obtidos com essa metodologia apontaram para uma comprovação da hipótese desta pesquisa, uma vez que foi observado um melhor desempenho na realização de tarefas nos participantes do Teste $\mathrm{B}$ que possuía interfaces que consideravam as diretrizes da interação entre humanos e robôs. Em particular a Tarefa 3, que foi escolhida como resposta a erros relativos à falta de informação sobre o espaço de trabalho do robô, relacionando o entendimento do usuário com a forma como o sistema expressa o mundo dos robôs. Na tarefa era pedido aos participantes que projetassem os elementos da operação no ambiente externo do teste a partir com a informação apresentada na interface. A diretriz de HRI medida procurou aumentar informação sobre ambiente operacional do Robô, e tornou os participantes mais conscientes dos elementos operacionais, resultando em um desempenho significantemente melhor no Teste B.

Em um panorama geral, os indivíduos que realizaram o Teste B com diretrizes não apenas obtiveram o maior índice de completude de tarefas, como também executaram tais tarefas de forma mais rápida, com menor índice de erros e também apresentaram maior satisfação com relação à usabilidade do teste realizado.

As técnicas aplicadas nesta dissertação não apenas auxiliaram na comprovação da hipótese da pesquisa, como também levaram a aprendizados quanto à aplicabilidade dos testes. O Teste de Usabilidade sofreu algumas adaptações às necessidades da pesquisa, em que se fez necessário replicar o cenário de uma operação robótica, similar a descrita pelos modelos de interação destacados na pesquisa. Dessa forma, foi preciso alinhamento da representação do mundo do robô representado na interface com o modelo mental de cada usuário, demandando diferentes aspectos de sua organização. Essa aplicabilidade se provou bem-sucedida em responder as questões dos testes e da dissertação, podendo ser utilizada em futuros estudos do gênero. Ademais, as experiências vivenciadas no Teste de Usabilidade, em especial a interação com o ambiente externo operacional, mostraram-se significativas para projetos como o do robô EMMA, visto terem evidenciado a necessidade de um volume de informação que aponte somente o necessário, mas que também o faça de forma específica e de acordo com as necessidades dos usuários para realizar atividades.

Por fim, as grandes conclusões alcançadas estão em torno de práticas que devem ser adotadas ao longo de todo processo de desenvolvimento de uma RUI, 
isto é, a prática de tornar a iteração um processo intrínseco no aprimoramento de GUI para sistemas robóticos. Neste âmbito, a avaliação heurística pode ser uma técnica adequada para tais aplicações, uma vez que possibilita medir as mesmas diretrizes em etapas diferentes do desenvolvimento.

Os desdobramentos da pesquisa relevantes à investigação e melhoria de RUIs estão ligados a outros objetivos na observação do trabalho coordenado com robôs. Aqui se teve o objetivo de pesquisar falhas comuns de interação, porém para aprofundar o conhecimento sobre a interação bem-sucedida com máquinas, muitos outros aspectos podem ser avaliados de acordo com a função do robô. Por exemplo, pode-se investigar agilidade e precisão de um robô ao executar uma tarefa, e neste contexto outros fatores humanos serão importantes de serem observados. Consequentemente, outras diretrizes de design podem ser testadas e aplicadas à avaliações heurísticas ou a testes de usabilidade de acordo com estes contextos diversos de uso. Por último, devido ao fato de que robôs estão se tornado mais comuns em nosso dia a dia e de interfaces de usuário estarem voltadas para um público cada vez mais amplo, testar com usuários não experientes, também se apresenta como um fator de desdobramento importante. 


\section{9 \\ Referências bibliográficas}

BAHADUR, Surya; SAGAR, B. Krishna; KONDREDDY, Mahesh Kumar. User interface design with visualization techniques. Int. J. Res. Eng. Appl. Sci, v. 2, n. 6, p. 53-55, 2012.

BARNUM, Carol M.; DRAGGA, Sam. Usability testing and research. Allyn \& Bacon, Inc., 2001.

BRYNJOLFSSON, Erik; MCAFEE, Andrew. The second machine age: Work, progress, and prosperity in a time of brilliant technologies. WW Norton \& Company, 2014.

CAMPANA, Julia Ramos; QUARESMA, Manuela. The Importance of Specific Usability Guidelines for Robot User Interfaces. In: International Conference of Design, User Experience, and Usability. Springer, Cham, 2017. p. 471-483.

CHEN, Jessie YC; HAAS, Ellen C.; BARNES, Michael J. Human performance issues and user interface design for teleoperated robots. IEEE Transactions on Systems, Man, and Cybernetics, Part C (Applications and Reviews), v. 37, n. 6, p. 1231-1245, 2007.

CLARKSON, Edward; ARKIN, Ronald C. Applying Heuristic Evaluation to Human-Robot Interaction Systems. In: Flairs Conference. 2007. p. 44-49.

CRAIG, John J. Introduction to robotics: mechanics and control. Upper Saddle River, NJ, USA:: Pearson/Prentice Hall, 2005.

CRANDALL, Jacob W. et al. Validating human-robot interaction schemes in multitasking environments. IEEE Transactions on Systems, Man, and Cybernetics-Part A: Systems and Humans, v. 35, n. 4, p. 438-449, 2005.

CRC Press. UK. 2013.

DEKKER, Sidney. Ten questions about human error: A new view of human factors and system safety. CRC Press, 2004.

DIX, Alan. Human-computer interaction. In: Encyclopedia of database systems. Springer US, 2009. p. 1327-1331. 
DIXON, Stephen R.; WICKENS, Christopher D.; CHANG, Dervon. Unmanned aerial vehicle flight control: False alarms versus misses. In: Proceedings of the Human Factors and Ergonomics Society Annual Meeting. Sage CA: Los Angeles, CA: SAGE Publications, 2004. p. 152-156.

DRURY, Jill L. et al. Design guidelines for improved human-robot interaction. In: CHI'04 extended abstracts on Human factors in computing systems. ACM, 2004. p. 1540-1540.

DRURY, Jill L.; SCHOLTZ, Jean; YANCO, Holly A. Awareness in human-robot interactions. In: Systems, Man and Cybernetics, 2003. IEEE International Conference on. IEEE, 2003. p. 912-918.

ENDSLEY, Mica; JONES, William M. Situation Awareness Information Dominance \& Information Warfare. LOGICON TECHNICAL SERVICES INC DAYTON OH, 1997.

FONG, Terrence et al. A personal user interface for collaborative human-robot exploration. In: 6th International Symposium on Artificial Intelligence, Robotics, and Automation in Space (iSAIRAS). 2001.

FONG, Terrence et al. Common metrics for human-robot interaction. In: IEEE 2004 International Conference on Intelligent Robots and Systems, Sendai, Japan. 2004.

FONG, Terrence; THORPE, Charles; BAUR, Charles. Collaboration, dialogue, human-robot interaction. In: Robotics Research. Springer, Berlin, Heidelberg, 2003. p. 255-266.

FORD, Martin. Rise of the Robots: Technology and the Threat of a Jobless Future. Basic Books, 2015.

GARCIA, Elena et al. The evolution of robotics research. IEEE Robotics \& Automation Magazine, v. 14, n. 1, p. 90-103, 2007.

GIKKAS ET AL. Automotive Ergonomics: Driver-Vehicle Interaction.

GIL, Antônio Carlos. Métodos e técnicas de pesquisa social. In: Métodos e técnicas de pesquisa social. 2015 .

GONÇALVES, Rafael Cirino; QUARESMA, Manuela. CARACTERIZAÇÃO E MODELAGEM DOS TIPOS DE ERRO HUMANO NA INTERAÇÃO COM SISTEMAS AUTOMATIZADOS. Blucher Design Proceedings, v. 2, n. 1, p. 1222-1233, 2015. 
HOLTZBLATT, Karen; JONES, Sandra. Contextual inquiry: A participatory technique for system design. Participatory design: Principles and practices, $p$. 177-210, 1993.

JORDAN, Patrick W. An introduction to usability. CRC Press, 1998.

KAWAMURA, Kazuhiko et al. Supervisory control of mobile robots using sensory egosphere. In: Computational Intelligence in Robotics and Automation, 2001. Proceedings 2001 IEEE International Symposium on. IEEE, 2001. p. 523-529. KEYES, Brenden et al. Improving human-robot interaction through interface evolution. In: Human-robot interaction. InTech, 2010.

KOWALSKI, E. Erro Humano e Consciência da Situação. Ergodesign/USIHC 2013 (Congresso). Juiz de fora - MG. 2013

KURFESS, Thomas R. (Ed.). Robotics and automation handbook. CRC press, 2004.

LAKATOS, Eva Maria; DE ANDRADE MARCONI, Marina. Metodologia científica. São Paulo: Atlas, 1991.

MILLER, Richard K. Industrial robot handbook. Springer Science \& Business Media, 2013.

MURPHY, Robin R. Rescue robotics for homeland security. Communications of the ACM, v. 47, n. 3, p. 66-68, 2004.

NAM, Chang S. et al. Evaluation of human-agent user interfaces in multi-agent systems. International Journal of Industrial Ergonomics, v. 39, n. 1, p. 192-201, 2009.

NAVEED, Sidra; RAO, Naveed Iqbal; MERTSCHING, Barbel. Multi robot user interface design based on HCI principles. Int. J. Hum. Comput. Interact. (IJHCI), v. 5, n. 5, p. 64, 2014.

NIELSEN, Jakob. Heuristic evaluation. V: Nielsen, J., RL Mack (ur.). Usability inspection methods. 1994

NIKU, Saeed. Introduction to robotics. John Wiley \& Sons, 2010.

NORMAN, Donald A. Design principles for human-computer interfaces. In: Proceedings of the SIGCHI conference on Human Factors in Computing Systems. ACM, 1983. p. 1-10.

PARASURAMAN, Raja Ed; MOULOUA, Mustapha Ed. Automation and human performance: Theory and applications. Lawrence Erlbaum Associates, Inc, 1996. 
PARASURAMAN, Raja; SHERIDAN, Thomas B.; WICKENS, Christopher D. A model for types and levels of human interaction with automation. IEEE Transactions on systems, man, and cybernetics-Part A: Systems and Humans, v. 30, n. 3, p. 286-297, 2000.

PARASURAMAN, Raja; SHERIDAN, Thomas B.; WICKENS, Christopher D. Situation awareness, mental workload, and trust in automation: Viable, empirically supported cognitive engineering constructs. Journal of Cognitive Engineering and Decision Making, v. 2, n. 2, p. 140-160, 2008.

RUBIN, Jeffrey; CHISNELL, Dana. Handbook of usability testing. 2008.

SCHOLTZ, Jean C. Human-robot interactions: Creating synergistic cyber forces. In: Multi-Robot Systems: From Swarms to Intelligent Automata. Springer Netherlands, 2002. p. 177-184.

SCHOLTZ, Jean. Evaluation methods for human-system performance of intelligent systems. NATIONAL INST OF STANDARDS AND TECHNOLOGY GAITHERSBURG MD MANUFACTURING ENGINEERING LAB, 2002.

SCHOLTZ, Jean. Theory and evaluation of human robot interactions. In: System Sciences, 2003. Proceedings of the 36th Annual Hawaii International Conference on. IEEE, 2003. p. 10 pp.

SHNEIDERMAN, B.; PLAISANT, C. Designing the User Interface. (4th Edition): Strategies for Effective Human Computer Interaction. NY: Pearson, 2005

SINGH, Ashish et al. An interface for remote robotic manipulator control that reduces task load and fatigue. In: RO-MAN, 2013 IEEE. IEEE, 2013. p. 738-743. PRODANOV, Cleber Cristiano; DE FREITAS, Ernani Cesar. Metodologia do Trabalho Científico: Métodos e Técnicas da Pesquisa e do Trabalho Acadêmico- $2^{\mathrm{a}}$ Edição. Editora Feevale, 2013.

STEINFELD, Aaron et al. Common metrics for human-robot interaction. In: Proceedings of the 1st ACM SIGCHI/SIGART conference on Human-robot interaction. ACM, 2006. p. 33-40.

TITTLE, James S.; ROESLER, Axel; WOODS, David D. The remote perception problem. In: Proceedings of the Human Factors and Ergonomics Society Annual Meeting. Sage CA: Los Angeles, CA: SAGE Publications, 2002. p. 260-264.

TREVELYAN, James; HAMEL, William R.; KANG, Sung-Chul. Robotics in hazardous applications. In: Springer handbook of robotics. Springer International Publishing, 2016. p. 1521-1548.) 
WOODS, David D. et al. Envisioning human-robot coordination in future operations. IEEE Transactions on Systems, Man, and Cybernetics, Part C (Applications and Reviews), v. 34, n. 2, p. 210-218, 2004.

YAMANOUCHI, Wataru et al. Bilateral teleoperation with dimensional scaling for realization of mobile-hapto. In: Industrial Electronics, 2008. IECON 2008. 34th Annual Conference of IEEE. IEEE, 2008. p. 1590-1595.

YOUNG, Stephen L.; PIERCE, Francis J. (Ed.). Automation: The Future of Weed Control in Cropping Systems. Springer Science \& Business Media, 2013. 


\section{Apêndice A - Termo de Consentimento das Entrevistas Contextuais}

LEUI $\mid$ Laboratório de Ergodesign e Usabilidade de Interfaces da PUC-Rio

Título da Pesquisa da Dissertação: Métodos para o design de interfaces gráficas de sistemas robóticos.

Nome do Pesquisador Responsável: Julia Ramos Campana

Nome do Professor Orientador: Prof. Dra. Maria Manuela Quaresma

Você está sendo convidado a ser um voluntário para responder uma entrevista desta pesquisa.

\section{Objetivo:}

O objetivo desta entrevista é o de entender os contextos em que robôs são usados, para compreender a hierarquia de execução e o comportamento do usuário na utilização de robôs. Desta forma, a pesquisadora busca compreender os objetivos de utilização e as respectivas tarefas e atividades nas quais se desdobram.

\section{Justificativa:}

Esta pesquisa tem por objetivo avaliar ao contexto em que robôs são utilizados para compreender melhor o comportamento do usuário e relacioná-los a princípios de design de interfaces. Esta inquirição servirá como base para os parâmetros de utilização nas interfaces robóticas utilizadas em testes de usabilidade.

\section{Procedimentos:}

Caso decida participar da entrevista, vamos solicitar que você relate de forma presencial como utiliza determinado robô para determinado propósito. O princípio da inquirição atende a uma relação entre mestre e aprendiz, onde o entrevistado explica ao entrevistador como utilizar o robô para que se compreenda o contexto e necessidade do usuário na interação em questão. A entrevista será presencial e agendada em local e horário de acordo com sua disponibilidade e preferência.

\section{Riscos:}

Não há riscos previsíveis ou desconfortos na entrevista e o pesquisador também não irá incentivar nenhuma atividade que possa trazer algum risco para o ambiente onde estarão presentes.

\section{Benefícios:}

Não há benefício ao participar desta entrevista. No entanto, sua participação é de grande importância para compreensão do contexto e aspectos comportamentais do usuário ao interagir com robôs. 


\section{Compensação:}

Não há nenhuma compensação por sua participação nesta entrevista. Os participantes/ voluntários irão receber, como forma de agradecimento pela participação, um brinde da pesquisadora.

\section{Informacões Coletadas:}

A entrevista será gravada em áudio, o entrevistador irá anotar suas observações em um bloco de notas para posteriormente interpretá-las e classificá-las.

Sigilo:

Para proteger o sigilo de sua identidade, seu nome não aparecerá em nenhuma publicação. Você receberá um pseudônimo (um nome falso) que será usado ao invés de seu nome. Todo material de áudio será tratado como confidencial e restrito para fins acadêmicos.

\section{Autorização para uso de imagens e declarações:}

Ao assinar este termo você autoriza o uso de suas declaracõos e voz para finalidade acadêmicas - artigos acadêmicos, aulas, papers, sites, apresentações em simpósios ou congressos científicos relacionados ao tema.

\section{Direito dos Participantes:}

Sua participação nesta entrevista é voluntária. Não há obrigatoriedade em participar. Se você necessitar de uma pausa a qualquer momento durante a entrevista, por favor, avise. Você tem o direito de mudar de ideia e interromper a entrevista a qualquer momento, sem apresentar motivos, não haverá penalização.

Qualquer alteração de regra que possa fazê-lo (a) mudar de ideia sobre participar da pesquisa será fornecida a você. Você receberá uma cópia deste documento de consentimento.

\section{Perguntas:}

Você poderá intervir e questionar a pesquisadora e entrevistadora sempre que achar necessário ou tiver dúvidas pelo telefone (21) 999481091 ou pelo email juliarcampana@gmail.com. Ou falar com a orientadora Manuela Quaresma pelo telefone (21) 981212596 ou pelo email mquaresma@puc-rio.br.

Data:

Assinatura: 


\title{
Apêndice B - Termo de Consentimento dos Testes de Usabilidade
}

\author{
TERMO DE CONSENTIMENTO LIVRE E ESCLARECIDO
}

LEUI $\mid$ Laboratório de Ergodesign e Usabilidade de Interfaces da PUC-Rio

Título da Pesquisa da Dissertação: Métodos para o design de interfaces gráficas de sistemas robóticos.

Nome do Pesquisador Responsável: Julia Ramos Campana

Nome do Professor Orientador: Prof. Dra. Maria Manuela Quaresma

Você está sendo convidado a ser um voluntário para participar de um Teste de Usabilidade.

Objetivo:

O objetivo deste Teste de Usabilidade é testar e validar diretrizes de design em interfaces de usuários de sistemas robóticos. Terminada a investigação, a pesquisadora também pretende publicar essa pesquisa em revistas acadêmicas e anais de congressos acadêmicos.

\section{Justificativa:}

Com este teste, pretende-se avaliar diretrizes de design para interfaces de usuários de sistemas robóticos na prevenção de falhas operacionais na interação com robôs de serviço. Além disso, busca-se reforçar a literatura vigente no que se refere ao desenvolvimento de interfaces robóticas, além de gerar conhecimento para pesquisadores da área de usabilidade, e servir como auxílio a órgãos governamentais, industriais ou de setores de produção que lidam com robótica.

\section{Procedimentos:}

Caso você decida fazer parte deste teste de usabilidade, vamos solicitar que você realize algumas tarefas apresentadas em um computador. Não há robô presente na atividade. A pesquisadora responsável e um (a) assistente irão conduzir o teste, explicando os procedimentos da sessão e o passo-a-passo do que você deverá realizar. A duração da sessão de teste será de aproximadamente 30 minutos. O procedimento do qual você participará visa somente atestar o uso das interfaces, pois não é você quem será testado (a).

\section{Riscos:}

Não há robôs envolvidos nos testes, apenas simulação de suas interfaces de usuários. Não há riscos previsíveis ou desconfortos no ambiente físico em questão. O pesquisador não irá incentivar nenhuma atividade que possa trazer algum risco para os participantes.

\section{Benefícios:}

Não há benefício ao participar deste teste. No entanto, sua participação é de grande importância para a avaliação de diretrizes no design de interfaces de usuários na interação robôs. 
Compensação:

Não há nenhuma compensação por sua participação neste teste.

\section{Informaç̃es Coletadas:}

O teste será gravado em vídeo, e o entrevistador irá anotar observações para posteriormente interpretá-las e classificá-las.

Sigilo:

Para proteger o sigilo de sua identidade, seu nome não aparecerá em nenhuma publicação. Você receberá um pseudônimo (um nome falso) que será usado ao invés de seu nome. Todo material de áudio e vídeo será tratado como confidencial e restrito para fins acadêmicos.

Autorização para uso de imagens e declarações:

Ao assinar este termo você autoriza o uso de suas declarações e voz para finalidade acadêmicas - artigos acadêmicos, aulas, papers, sites, apresentações em simpósios ou congressos científicos relacionados ao tema.

Direito dos Participantes:

Sua participação neste teste é voluntária. Não há obrigatoriedade em participar. Se você necessitar de uma pausa a qualquer momento durante o teste, por favor, avise. Você tem o direito de mudar de ideia e interromper o teste em qualquer momento, sem apresentar motivos ou sem qualquer de penalização.

Qualquer alteração de regra que possa fazê-lo (a) mudar de ideia sobre participar da pesquisa será fornecida a você. Você receberá uma cópia deste documento de consentimento

\section{Perguntas:}

Você poderá intervir e questionar a pesquisadora e entrevistadora sempre que achar necessário ou tiver dúvidas pelo telefone (21) 999481091 ou pelo email

juliarcampana@gmail.com. Ou falar com a orientadora Manuela Quaresma pelo telefone (21) 981212596 ou pelo email mquaresma@puc-rio.br.

Data:

Assinatura: 


\title{
Apêndice C - Perguntas das Entrevistas Contextuais
}

\author{
1. O que é preciso para ligar o robô? \\ 2. Como você o liga? Por favor descreva o passo a passo de forma detalhada, incluindo \\ eventuais precauções com o sistema. \\ 3. Algum procedimento de segurança inicial? \\ 4. Algum procedimento inicial de script para conectar o sistema? \\ 5. Enumere todos os dispositivos necessários para realização da operação? Algum deles \\ necessita de funcionamento independente antes da operação? \\ 6. Qual o propósito de utilização deste robô? \\ 7. O que é preciso para opera-lo? \\ 8. Como você realiza esta tarefa com o robô? \\ 9. Quais as dificuldades na operação? \\ 10. Existem atalhos para facilitar essa utilização? Se sim, quais? \\ 11. Qual o procedimento em caso de erro do sistema? \\ 12. Qual o procedimento em caso de emergência? \\ 13. Como você sabe que ocorreu um problema com o sistema? É possível localiza-lo? \\ 14. Relate casos de uso ou histórias do robô que possam ser úteis ou descrever aspectos \\ importante de sua utilização.
}




\section{Apêndice D - Formulário do Teste A}

Formulário Teste 1

\begin{tabular}{l} 
Nome Participante: \\
Código: \\
Grupo: \\
\hline Checklist pré-teste: \\
- Quicktime on ( ) \\
- Timer on ( ) \\
- Consentimento assinado ( ) \\
- Apresentação de teste ( )
\end{tabular}

TAREFA 1

Compreendeu corretamente o que deve ser feito na tarefa?
[ ] sim
[ ] não
[ ] apenas depois de ajuda

Acertou a seleção de dropdowns?
[ ] $\operatorname{sim}$
[ ] não
[ ] parcialmente

TAREFA 2

Compreendeu corretamente o que deve ser feito na tarefa?
[ ] $\operatorname{sim}$
[ ] não
[ ] apenas depois de ajuda

Selecionou a área certa no dropdown?
[ ] sim
[ ] não

\section{TAREFA 3}

Compreendeu corretamente o que deve ser feito na tarefa?
[ ] $\operatorname{sim}$
[ ] não
[ ] apenas depois de ajuda

Conseguiu montar o ambiente de acordo com a informação da interface?
[ ] sim
[ ] não
[ ] parcialmente

\section{TAREFA 4}

Compreendeu corretamente o que deve ser feito na tarefa?
[ ] $\operatorname{sim}$
[ ] não
[ ] apenas depois de ajuda

Completou a calibração?
[ ] sim
[ ] não
[ ] parcialmente

\section{TAREFA 5}

Indique opção foi marcada:

[ ] 0 sistema agiu corretamente

[ ] 0 sistema falhou

[ ] Não posso afirmar 


\section{Apêndice E - Formulário do Teste B}

Formulário Teste 2

Código:

Grupo:

\section{Checklist pré-teste:}

- Quicktime on ( )

- Timer on ( )

- Consentimento assinado ( )

- Apresentação de teste ( )

\section{TAREFA 1}

Compreendeu corretamente o que deve ser feito na tarefa?
[ ] sim
[ ] não
[ ] apenas depois de ajuda

Acertou a seleção de dropdowns?
[ ] $\operatorname{sim}$
[ ] não
[ ] parcialmente

TAREFA 2

Compreendeu corretamente o que deve ser feito na tarefa?
[ ] $\operatorname{sim}$
[ ] não
[ ] apenas depois de ajuda

Selecionou o quadrante certo no grid?

[ ] sim [ ] não [ ] parcialmente (selecionou mais de 1

quadrante ou não soube desfazer seleção de quadrante errado)

TAREFA 3

Compreendeu corretamente o que deve ser feito na tarefa?

[ ] sim [ ] não [ ] apenas depois de ajuda

Conseguiu montar o ambiente de acordo com a informação da interface?

[ ] sim [ ] não [ ] parcialmente

Acessou todos as imagens com informação do ambiente?
[] $\operatorname{sim}$
[ ] não
[ ] algumas
Se não todas, quais?

[ ] posições

[ ]

TAREFA 4

Compreendeu corretamente o que deve ser feito na tarefa?
[ ] $\operatorname{sim}$
[ ] não
[ ] apenas depois de ajuda

Completou a calibração?
[ ] $\operatorname{sim}$
[ ] não
[ ] parcialmente

TAREFA 5

Indique opção foi marcada:

[ ] 0 sistema agiu corretamente

[ ] 0 sistema falhou

[ ] Não posso afirmar 
Apêndice F - Interfaces do Teste A

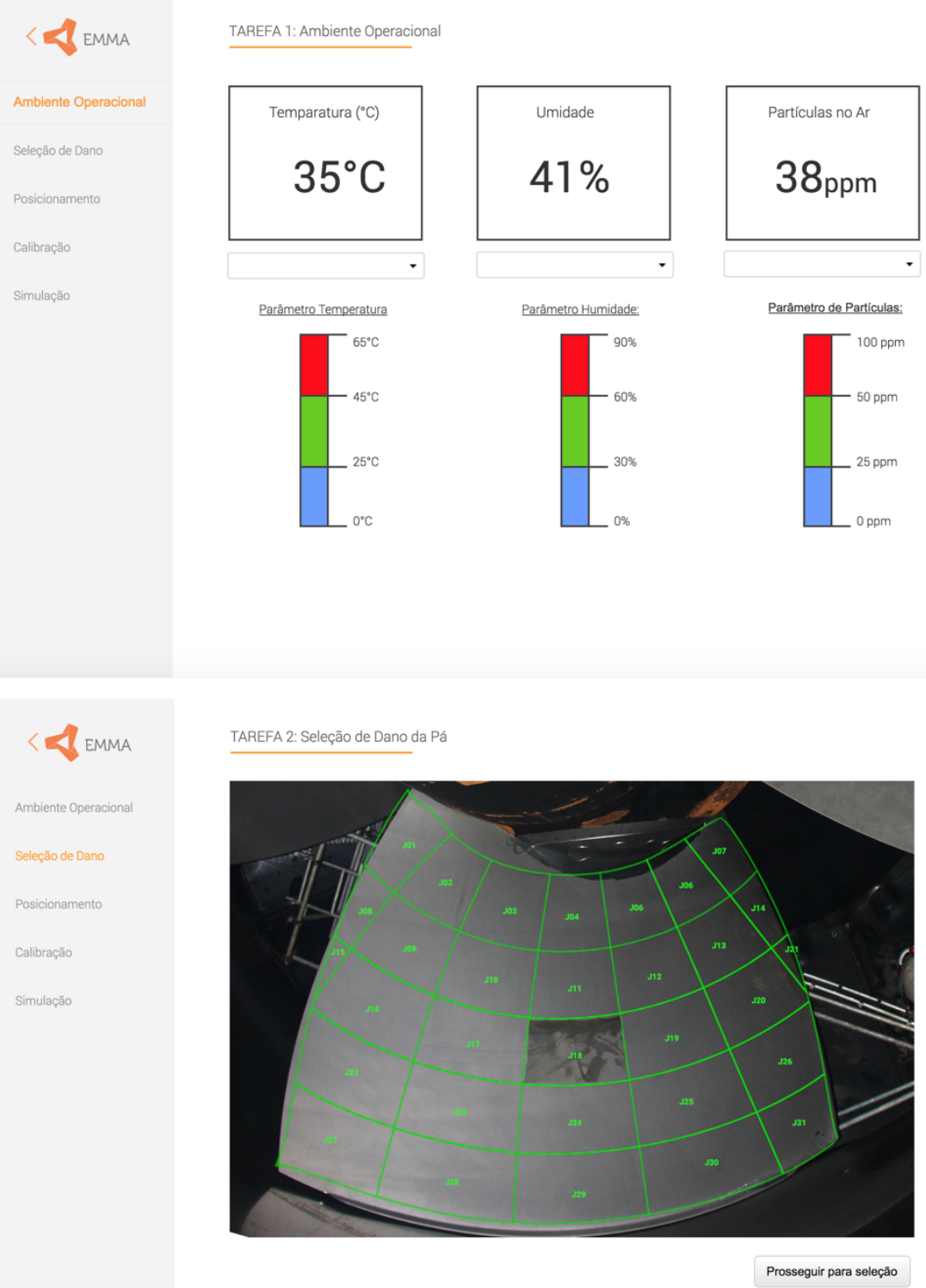



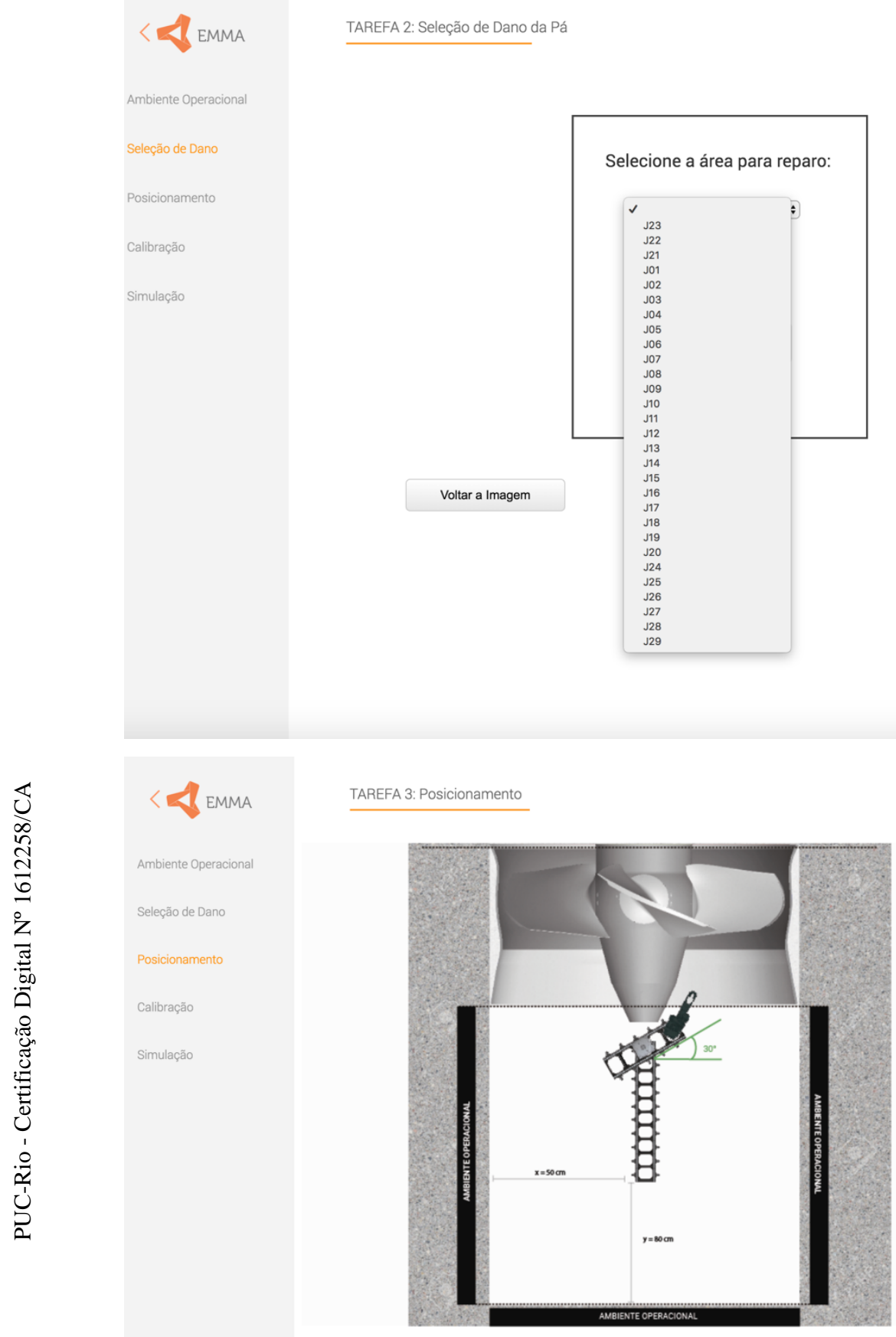


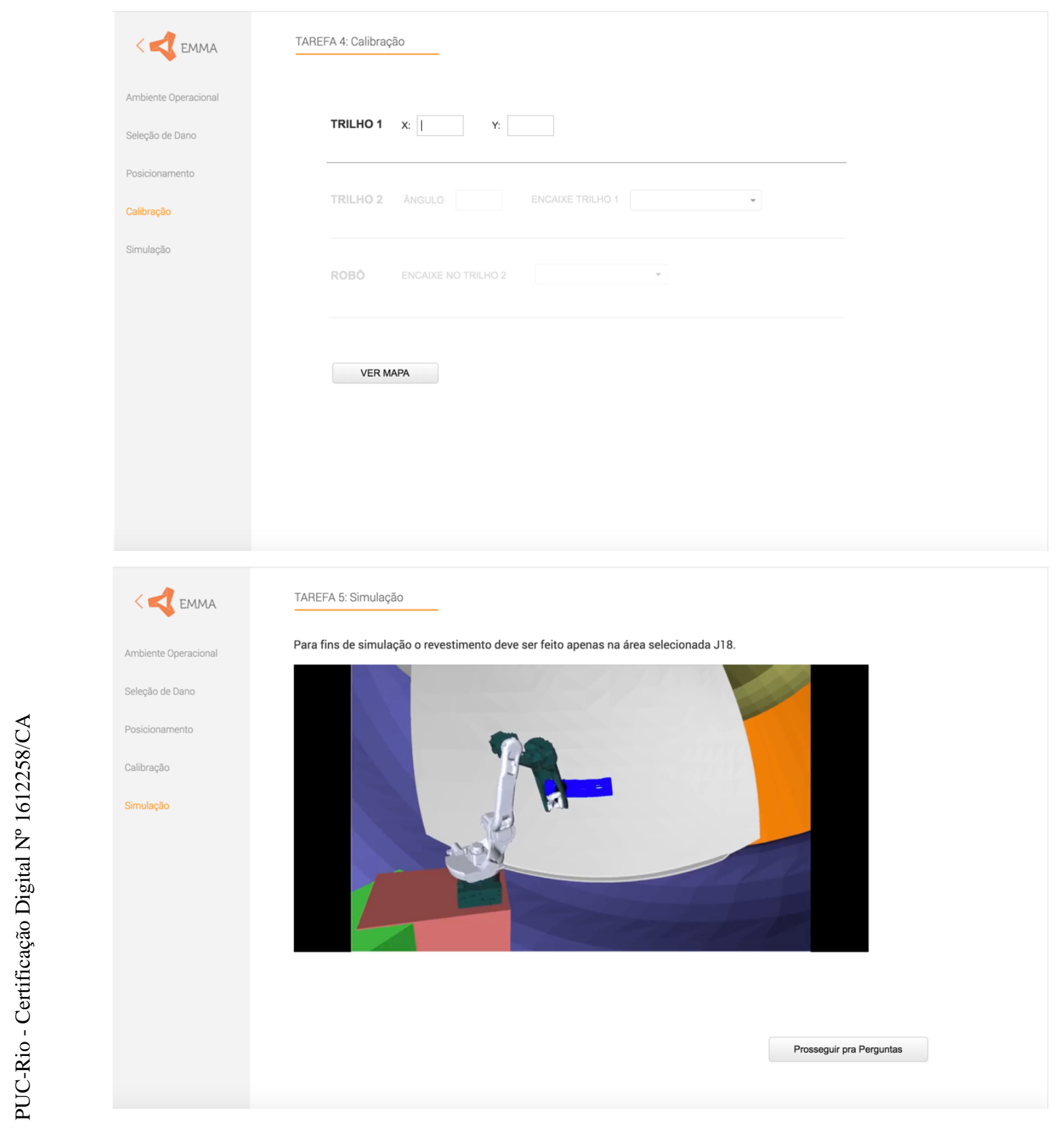




\section{Apêndice G - Interfaces do Teste B}

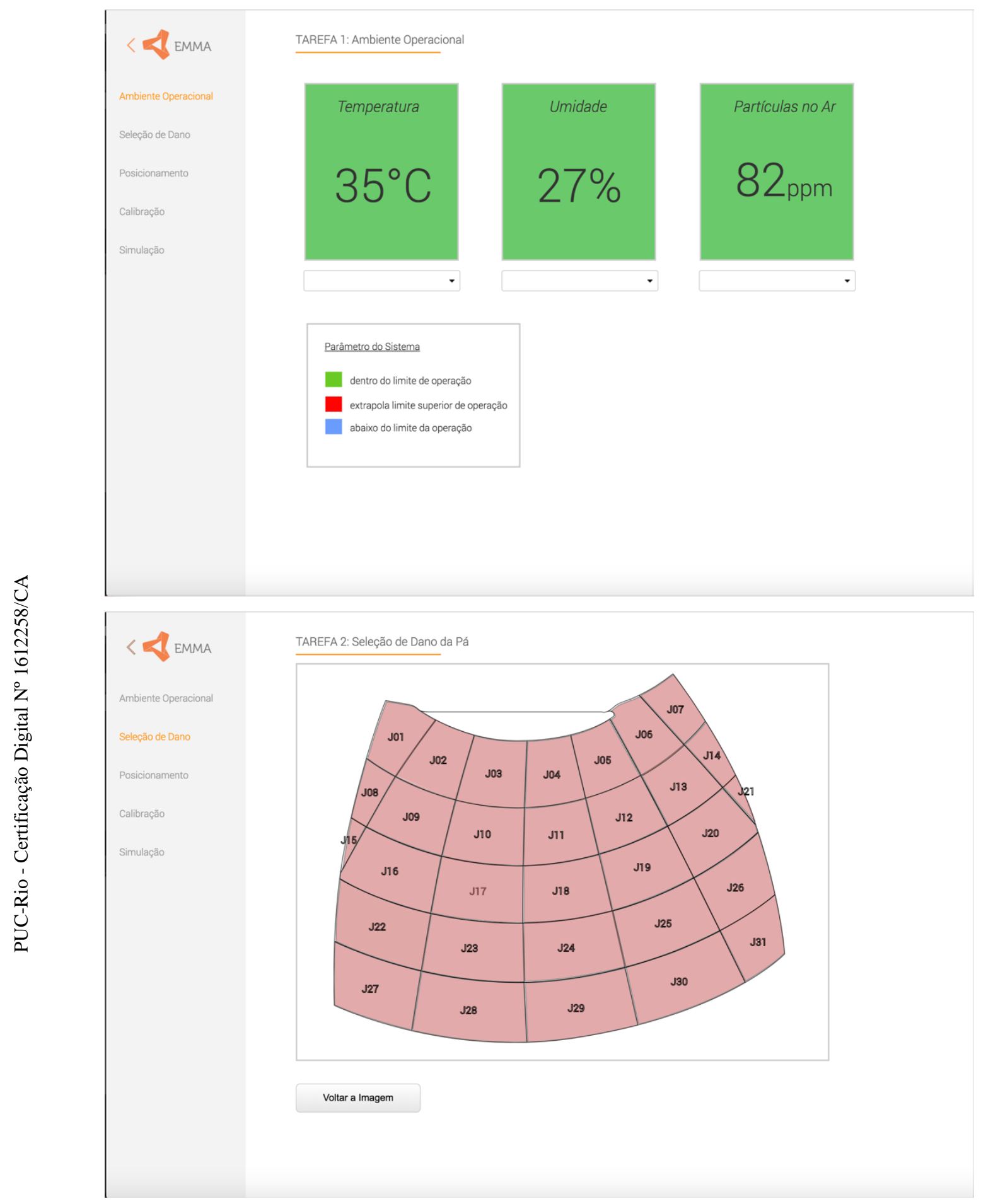



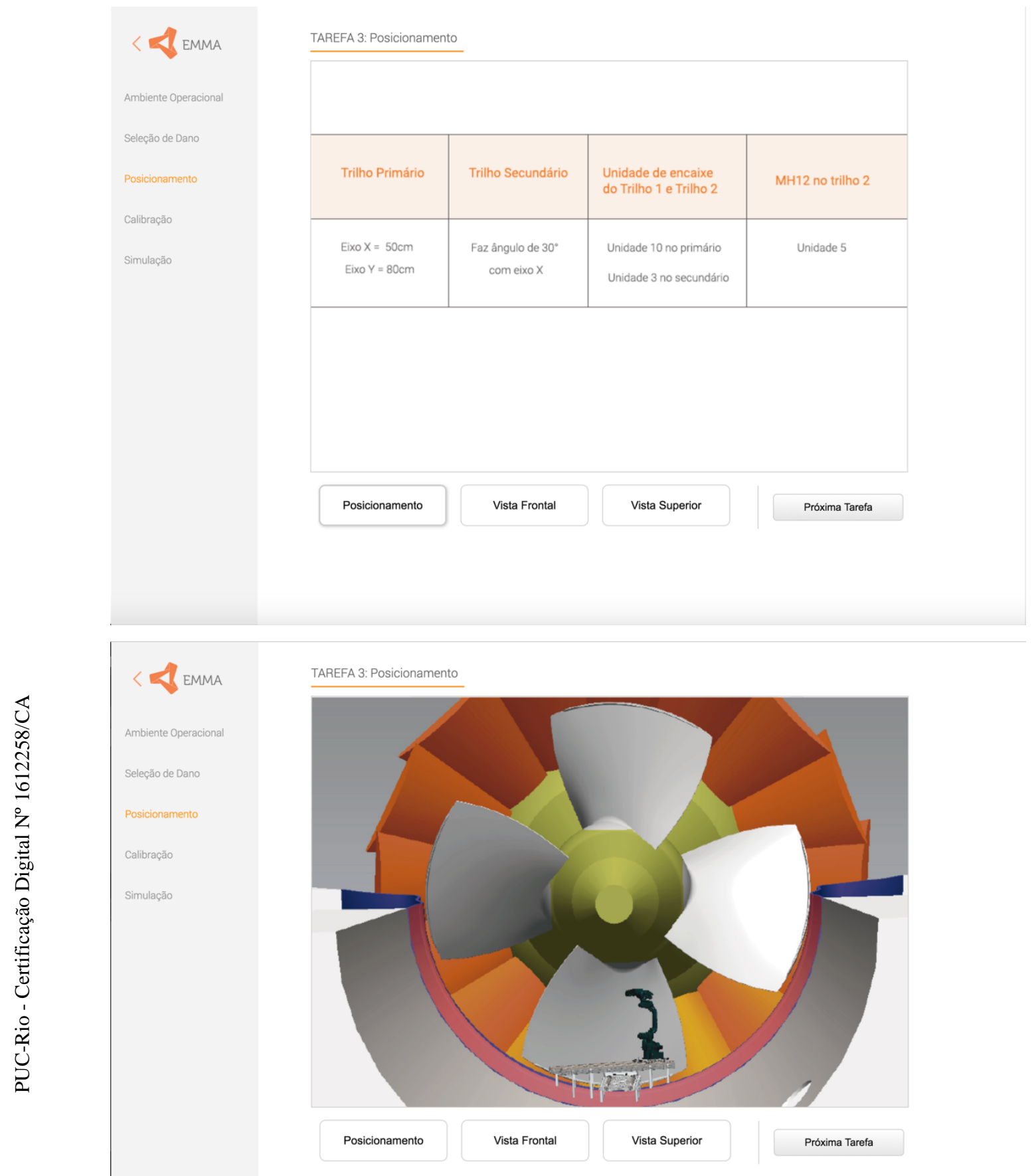

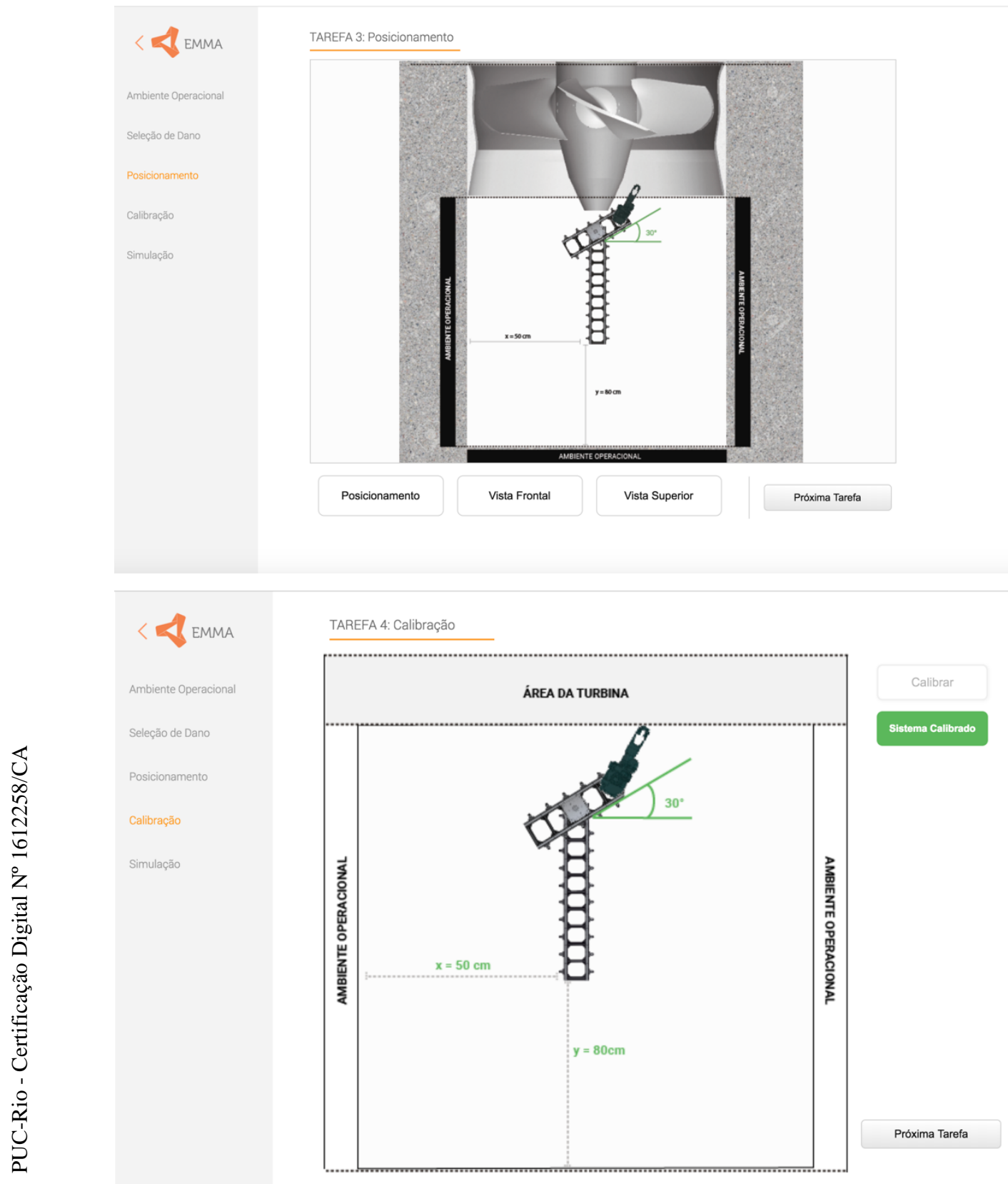


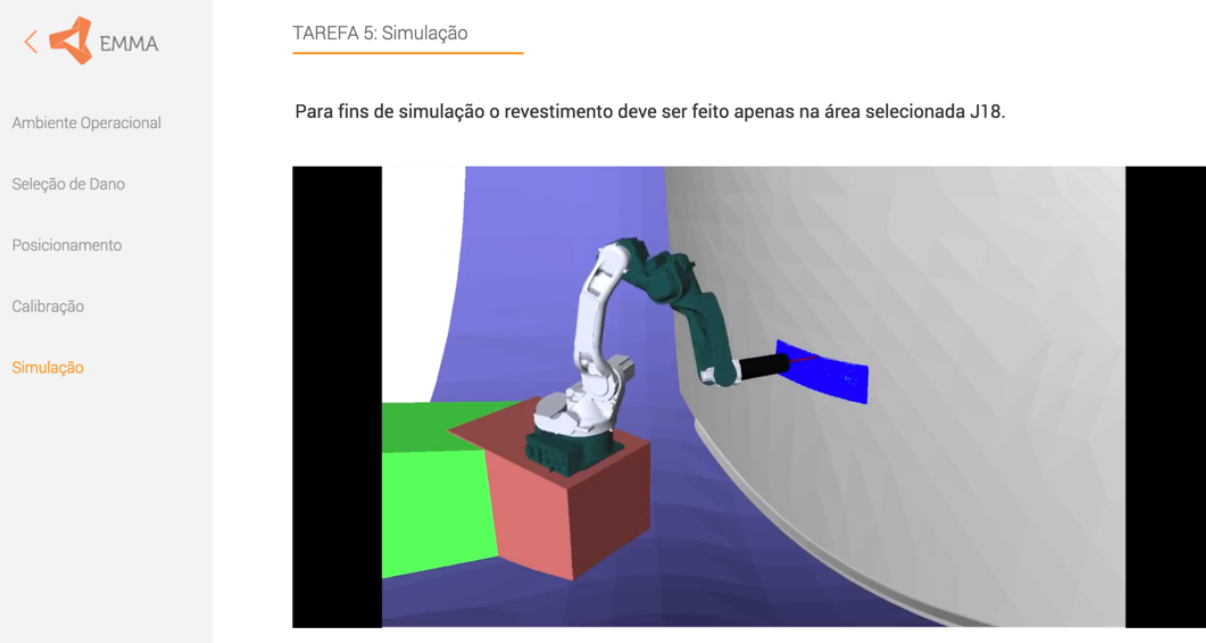




\section{Apêndice H - Tratamento dos Resultados do SUS}

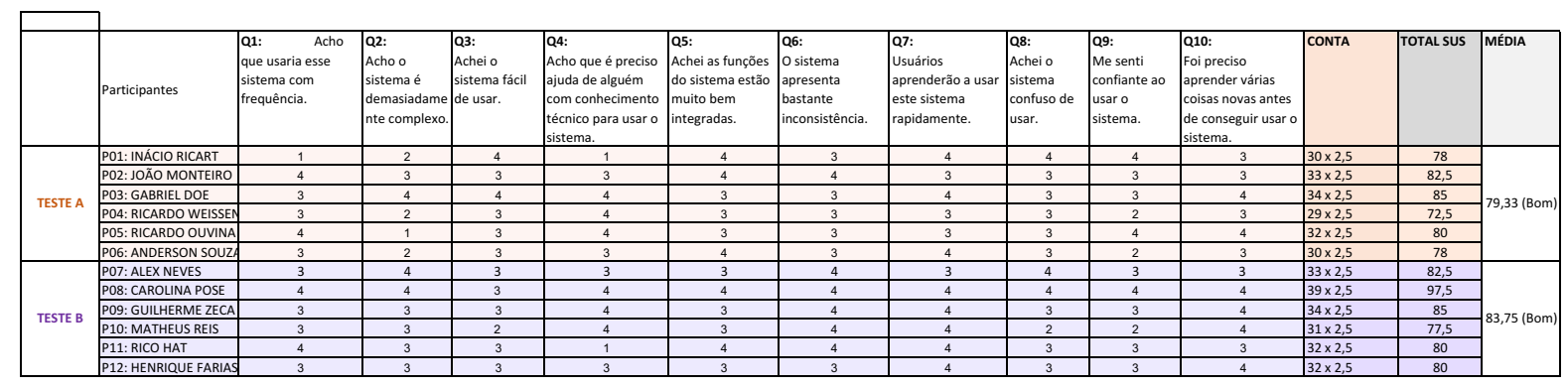

